\title{
LA APLICACIÓN JUDICIAL DE LOS DERECHOS DE INFORMACIÓN, CONSULTA Y CONTROL SINDICAL*
}

\author{
Carlos Hugo Preciado Domènech \\ Magistrado de lo Social del Tribunal Superior de Justicia de Cataluña
}

Orcid: 0000-0002-7525-8976

Recibido el 30 de septiembre de 2016

DOI: $10.1387 /$ lan-harremanak.17489

Aceptado el 15 de octubre de 2016

\section{ABSTRACT}

Resumen: La negociación colectiva de empresa o sector carece en el Reino de España de una regulación legal precisa de los derechos de información de los representantes de los trabajadores. En contraste, en los casos de negociaciones empresariales en situaciones de crisis empresarial, el legislador es exhaustivo al regular los derechos de información y consulta. Esta situación no es coherente con la filosofía de la flexiguridad, que impondría negociaciones informadas y dotadas de contenido en situaciones de normalidad empresarial con el fin, precisamente, de evitar situaciones de crisis. En este artículo se analiza esta realidad desde una perspectiva a varios niveles: comunitario, constitucional y legal; mostrando una opinión critica con el rigor de la doctrina judicial, que concibe el derecho de información como un derecho de configuración legal, en lugar de flexibilizar la su interpretación para tutelar la negociación colectiva como derecho fundamental, que no puede ser efectivo sin la información previa necesaria.

* Ponencia presentada en el II Encuentro de Profesionales del Asesoramiento Laboral y Social NEGOCIACIÓN COLECTIVA Y CONTROL SINDICAL. ASPECTOS LABORALES Y ECONÓMICOS, 29 y 30 de septiembre de 2016. Facultad de Relaciones Laborales y Trabajo Social UPV-EHU (Leioa). 
Abstract: The collective bargaining of companies or sectors lacks in the Kingdom of Spain a precise legal regulation of the information rights of workers' representatives. In contrast, in the cases of business negotiations in situations of business crisis, the legislator is exhaustive in regulating the rights of information and consultation. This situation is not consistent with the philosophy of flexicurity, which would impose informed and content negotiations in situations of business normality in order -precisely- to avoid crisis situations. This article analyzes this reality from a multilevel perspective: European Union, constitutional and legal; showing a critical opinion with the rigor of judicial doctrine, which conceives the right to information as a right of legal configuration, rather than flexibilizing its interpretation to protect collective bargaining as a fundamental right, which can not be effective without prior information required. 


\section{SUMARIO}

Sumario: 1. Consideraciones preliminares. 2. El marco normativo y doctrinal de los derechos de información, audiencia y consulta. 2.1. El marco de la UE: el derecho fundamental a la participación de los trabajadores en la empresa. 2.1.1. Derecho originario. 2.1.2 Derecho derivado. 2.1.2.1. La Directiva Marco 2002/14 en materia de información y consulta. A) Concepto de información y consulta. B) Momento, forma y contenido apropiados. 2.2. Marco doctrinal en la UE. 2.2.1. Libertad de empresa y derechos de información y consulta: la degradación del derecho fundamental a la información y consulta. 2.2.2. El marco comunitario de información y consulta como derecho mínimo. 2.2.3. Ámbito de aplicación: empresa, centro de trabajo, grupos de empresa. A) El concepto de centro de trabajo. a) Resumen de la evolución doctrinal e la materia. B) Grupos de empresa. 2.3. Conclusiones críticas. 3. OIT. 4. Consejo de Europa. 5. Derecho interno. 5.1. Constitución. 5.2. Leyes. 5.2.1. El art. 64 ET. 5.3. Autonomía colectiva. 6. Marco doctrinal interno. 6.1. El convenio como instrumento de mejora de los derechos de información y consulta. 6.2. Negociación colectiva y derechos de información y consulta. 6.3. Cuestiones relativas al contenido del derecho. 6.4 Criterio restrictivo o numerus clausus del contenido del derecho de información. 6.5. Concepto abierto: información para ejercer funciones constitucionalmente reconocidas. 6.6. La sorprendente doctrina de la falta de necesidad de notificar a los representantes de los trabajadores los despidos individuales realizados en el marco de un despido colectivo. 6.7. El criterio restrictivo en el plano procesal. 6.8. Contraste entre el criterio de flexibilidad e instrumentalidad en la documentación a entregar en los despidos colectivos y el legalismo formalista en la interpretación de los derechos de información y consulta. 6.8.1. Criterio flexible y finalista en despidos colectivos. 6.8.2. Criterio literalista y rigorista en información y consulta del art. 64 ET. 7. Cuestiones de titularidad. 7.1. Las secciones sindicales mixtas en la Administración Pública. 7.2. Delegados de prevención. 7.3. Los sindicatos no son titulares, las secciones sindicales sí. 7.4. La exclusión de un sindicato del derecho de información es vulnerar la libertad sindical. 7.5. Delegados sindicales de sindicaros que tienen representación en el comité de empresa. 7.6. Sección sindical de sindicato no firmante del convenio. 8. Limites de los derechos de información y consulta. 8.1. Límites constitucionales al derecho a la información. 8.1.1. Derecho al honor. 8.1.2. Derecho a la intimidad. 8.1.3. Derecho a la protección de datos. Doctrina de los Tribunales y criterios de la AEPD. 8.1.3.1. Doctrina TJUE. 8.1.3.2. Doctrina TC. 8.1.3.3. Doctrina TS. 8.1.3.4. Doctrina AN. 8.1.3.5. Doctrina TSJ. 8.1.3.6. Criterios de la AEDP. A) Datos profesionales: retribuciones, relaciones de trabajo, nóminas, etc. B) Cesión de datos a Comité de Empresa. C) Cesión de datos secciones sindicales. 8.2. Límites estatutarios. 8.2.1. Finalidad de la información y ámbito de la empresa. 8.2.2. Sigilo profesional. 8.2.3. Secretos industriales, financieros o comerciales. 9. Bibliografía. 10. Jurisprudencia. 


\section{Consideraciones preliminares}

El régimen jurídico actual de la documentación e información económica, productiva y laboral para la negociación colectiva de convenios estatutarios en la empresa y sector se halla, a nivel legal, en la más completa anomia. Sólo el deber de buena fe del art. 89.3 ET y los propios pactos que en desarrollo del mismo alcancen las partes durante la negociación puede colmar dicha laguna. Con todo, existe una diferencia que conviene perder de vista, cual es el nivel de negociación, pues en la empresa o ámbito inferior los negociadores pueden y deben contar con la información que el art. 64 ET. En cambio, en el nivel supra empresarial la regulación es legalmente inexistente, siendo paradójicamente el nivel que afecta a más trabajadores y empresarios.

Esta anomia en la negociación «fisiológica» no es un problema nuevo. Poco antes de la CE78, los Pactos de la Moncloa de 27 de octubre de 1977 contenían disposiciones tendentes a facilitar a los trabajadores la información sobre la situación económica de su Empresa. Concretamente, en los puntos 4 y 5 de su apartado D), dedicado a la Política de rentas, prevé que se adopten criterios de mejora de la información periódica sobre resultados de la empresa y su difusión responsable a las fuerzas sociales que en la misma participan.

Más adelante, en la Resolución de 29 de marzo 1978 de la Dirección General de Trabajo, cuyo objeto era el de facilitar el importe de la masa salarial a las comisiones negociadoras en los Reales Decretos-leyes 42/1977, de 25 noviembre y 49/1978, de 26 diciembre, dictados en ejecución del Acuerdo núm. 5 de los denominados Pactos de la Moncloa; se contemplan determinadas disposiciones sobre información en la negociación colectiva de empresa y en la de Sector ${ }^{1}$. Más

1 Resolución 29 enero 1978.

1..$^{\circ}$ En los supuestos en los que no exista conformidad en la Comisión Deliberante de un Convenio Colectivo, en orden a la determinación de la masa salarial, cualquiera de las partes podrá dirigirse a la autoridad laboral correspondiente, a través del Presidente de la Comisión, a fin de que éste recabe de la Empresa o Empresas afectadas o, en su caso, de la Delegación de Hacienda o Entidad financiera que corresponda, testimonio de la declaración oficial presentada conforme a lo prevenido en el número 1 del artículo $8 .^{\circ}$ del Real Decreto-Ley 43/1977 (RCL 1977\2470).

2. En los Convenios del sector, en los que resulten afectadas un gran número de Empresas, podrá hacerse esta misma solicitud referida a un número de ellas que se considere suficientemente representativo, por designación de las partes, o, en su defecto, por decisión de la autoridad laboral.

3. ${ }^{\circ}$ La autoridad laboral, una vez recibido los testimonios a que se refieren los puntos anteriores, emplazará a la representación de los trabajadores para, en concordancia con lo dispuesto en los arts. 63 y 91 de la Ley de Procedimiento Administrativo, de 17 de julio de 1958 (RCL 1958\1258, 1469, 1504; RCL 1959\585 y NDL 24708), darles vista de la mencionada comunicación. Cumplido este trámite, se reanudarán las deliberaciones del Convenio partiendo de la fase en que se interrumpieron. 
adelante, el Estatuto de los Trabajadores de 1980 (Ley 8/80 de 10 de marzo) contempla en su art. 64 las competencias del comité de empresa, donde se regulan derechos de información y consulta.

Dichas competencias pasaron al art. 64 Texto Refundido del RDL 1/1995. El precepto en cuestión fue modificado por la LO 3/07, de 22 de marzo, de igualdad la trasposición — tardía - de la Directiva 2002/14, que fue traspuesta a nuestro ordenamiento por la Ley 38/07 de 16 de noviembre. Más adelante, el RD-Ley 15/98 de 27 de noviembre lo modificó en relación a la información sobre contratos a tiempo parcial. Finalmente, el actual Texto Refundido del ET, aprobado por RDL 2/2015 de 23 de octubre, vigente desde 13 de noviembre de 2015.

Ante esta situación, como luego tendremos ocasión de comprobar con mayor detalle, tradicionalmente los Tribunales de lo social han adoptado una concepción de los derechos de información y consulta como derechos de configuración legal, sin que el banco social en las negociaciones colectivas pueda exigir otra información que la legalmente establecida, en el caso de las negociaciones a nivel de empresa, la del art. 64 ET, y en el caso de las de Sector la que marque el contenido y la buena fe en la negociación.

En esta línea, en materia de información en el ámbito de sector, destaca la SAN 53/1997 de 18 abril (AS 1997\2391) donde se aprecia que respecto a los integrantes del banco social en las mesas de la negociación colectiva, el contenido de la información que les corresponde conocer es el requerido por el mismo contenido de la negociación y que debe ajustarse a lo que normalmente exige la misma, atendida la finalidad de la institución del convenio colectivo, configurada bajo el principio de la buena fe negocial a que hace referencia el art. 89.1 ET y - dada siempre la semejanza del bien jurídico protegido en una y otra situación - respetando desde luego los límites legales para que actuaciones legales de algún modo paralelas, se establecen en el mencionado art. 64.1 ET y con aplicación del principio de confidencialidad que para su concreta regulación se establece también en el art. 65 ET respecto de los órganos de la representación unitaria de la empresa.

Esta conceptuación del derecho a la información en la negociación como derecho de configuración legal ordinaria debería revisarse si se parte de la consideración de la negociación colectiva como parte integrante de la acción sindical y, por tanto, del derecho fundamental a la libertad sindical. Sin embargo no es esa la vía que ha seguido tradicionalmente el TS, (ej. STS 10 diciembre 2013 (RJ 2014/2389) que dice que la negociación colectiva no es en sí misma un derecho fundamental. Ello a pesar de su ubicación (Sección 2. ${ }^{a}$ del Capítulo II del Título I de la CE) y de que forma parte del contenido esencial de la libertad sindical (art. 28 CE) (Preciado, 2016: 25 y ss.). 
No obstante, la negociación colectiva es un medio principal de acción sindical y el instrumento básico de participación de los sindicatos en las condiciones de trabajo (SSTC 73/84, 224/00, etc). Así resulta del art. 8.2 b) LOLS, que desarrolla el art. $28 \mathrm{CE}$ y de la doctrina del TC que ha considerado que la negociación colectiva es contenido adicional de la libertad sindical (STC 85/01).

En este sentido, el TC ha considerado (STC 208/93) que el reconocimiento de la libertad sindical y de la función del sindicato de contribuir a la defensa y promoción de los intereses de los trabajadores, le atribuye consiguientemente el ejercicio de aquellos derechos necesarios para el cumplimiento de tal función, como manifestación ineludible de la libertad sindical, de forma que el impedimento o la obstaculización a tal ejercicio puede constituir vulneración del art. 28.1 CE (STC 118/1983 [RTC 1983\118]). De este modo, aunque el derecho a la negociación colectiva esté reconocido en el art. 37.1 CE y no es por ello un derecho fundamental que, como tal, sea susceptible de protección a través del recurso de amparo (SSTC 118/1983, 45/1984 [RTC 1984145], 98/1985 [RTC 1985\98]), el TC ha considerado que determinadas lesiones del derecho de negociación colectiva cuando se dan frente a un sindicato $y$, por su entidad y trascendencia, supongan una radical y arbitraria eliminación o desconocimiento del mismo y de la autonomía colectiva, pueden propiciar el amparo constitucional por deducirse de esa conducta una lesión directa del derecho a la libertad sindical (ATC 1074/1988). En tales casos, el obstaculizar o el desvirtuar la facultad negociadora colectiva del sindicato, no sólo vulneraría los preceptos legales correspondientes y, por ende, el art. 37.1 CE, sino también el derecho fundamental a la libertad sindical (SSTC 187/1987 [RTC 1987\187], 108/1989 [RTC 1989\108] y 105/1992 [RTC 1992\105]).

En este punto, si bien es cierto que no toda infracción de la negociación colectiva (art. 37.1 CE) es una infracción de la libertad sindical (art. 28 CE); no es menos cierto que una negociación sin información — sin conocimiento de causa (Recomendación 163 OIT) — afecta al núcleo esencial del derecho a la negociación, puesto que ni es una negociación transparente, ni el consentimiento que pueda prestarse por los negociadores será un consentimiento informado, por lo que bien pudiera considerarse uno de aquellos casos que el TC entiende como los que suponen la radical y arbitraria eliminación o desconocimiento del derecho a la negociación colectiva y de la autonomía colectiva, sobre todo cuando la otra parte dispone de la información que se pide y la misma es imprescindible para abordar una negociación en condiciones de igualdad.

Por esa razón, sería algo más que recomendable establecer un marco legal que garantizase una información mínima tanto a nivel de Sector o supraempresarial, como a nivel de empresa o ámbito inferior a fin de garantizar que la negociación colectiva cumple su función iusfundamental de garantizar una acción sindical que tenga por finalidad la defensa de los intereses sociales que les son 
propios (art. 7 CE). De esta forma - de paso- se daría cumplimiento al mandato del el art. 5.2d) del Convenio n. ${ }^{\circ} 154$ de la OIT que obliga a los Estados a adoptar medidas adecuadas a las condiciones nacionales para fomentar la negociación colectiva, en concreto las que tengan por objeto que la negociación colectiva no resulte obstaculizada por la inexistencia de reglas que rijan su desarrollo o la insuficiencia o el carácter impropio de tales reglas.

Para apoyar tal conclusión, no podemos dejar de subrayar el contraste de esta falta de regulación o anomia legal del información en la negociación que podemos denominar "fisiológica», que se desarrolla en condiciones de normalidad empresarial; con la regulación detallada, reglamentista y con tintes de exhaustividad que presenta lo que podríamos denominar negociación en supuestos de crisis (art. 41.4, art. 47, 51.2, ET y arts. 4, 5 y 18 del RD 1483/12), lo que mueve a reflexión puesto que si en las situaciones de crisis empresarial la información se revela como imprescindible para abordar los procesos de consulta; no se comprende muy bien, partiendo de la filosofía de la flexiguridad, cómo podemos tener aún esa falta de regulación sobre la información en los procesos de negociación colectiva fisiológica, como medio de flexibilidad interna, que tiene, entre otras finalidades, adecuar las condiciones de trabajo a la realidad de las empresas y del sector y evitar acudir así a fórmulas traumáticas de flexibilidad externa.

Hechas estas consideraciones preliminares, abordaremos el marco normativo y doctrinal de los derechos de información, audiencia y consulta; y lo haremos tanto a nivel de la UE, OIT y Consejo de Europa, como a nivel interno, para analizar los problemas que fundamentalmente se plantean en la aplicación práctica de los derechos de información.

\section{El marco normativo y doctrinal de los derechos de información, audiencia y consulta}

\subsection{El marco de la UE: El Derecho fundamental a la participación de los trabajadores en la empresa}

Dentro del Derecho de la UE distinguiremos en la regulación de los derechos de información y consulta de los trabajadores en el Derecho originario y en el Derecho derivado (Navarro, 2010: 419 y ss.).

\subsubsection{Derecho originario}

La Política Social, en la que se enmarcan los derechos de información y consulta es una materia en que la UE ostenta competencia compartida (art. 4.2b) TRUE), por lo que conforme al art. 5.3 del TUE se rige por el principio de sub- 
sidiariedad, en cuya virtud la UE intervendrá sólo en caso de que, y en la medida en que, los objetivos de la acción pretendida no puedan ser alcanzados de manera suficiente por los estados miembros, ni a nivel central ni a nivel regional y local, sino que puedan alcanzarse mejor, debido a la dimensión o a los efectos de la acción pretendida, a escala de la Unión ${ }^{2}$.

Por otro lado, conforme al art. 153.2 TFUE, en el ámbito de información y consulta a los trabajadores e Parlamento y el Consejo pueden adoptar Directivas conforme al procedimiento legislativo ordinario (mayoría) y previa consulta al CES y al CR.

El art. 153.1 e) del TFUE establece que para conseguir los objetivos del art. $151^{3}$, la UE apoyará y completará la acción de los estados miembros en materia de información y consulta a los trabajadores, a cuyo fin podrán adoptar mediante directivas, las disposiciones mínimas que han de aplicarse progresivamente, teniendo en cuanta las condiciones y reglamentaciones técnicas existentes en cada uno de los Estados miembros.

En su apartado f) el art. 153.1 TFUE contempla la representación y la defensa colectiva de los intereses de los trabajadores y de los empresarios, incluida la cogestión.

$\mathrm{El}$ art. 27 CDFUE establece que debe garantizarse a los trabajadores o a sus representantes, en los niveles adecuados, la información y consulta con suficiente antelación, en los casos y condiciones previstos en el Derecho de la Unión y en las legislaciones y prácticas nacionales. Dicho precepto, conforme al art. 6 TUE tiene el mismo valor jurídico que los Tratados.

Cabe también citar, aun partiendo de su naturaleza meramente programática, sin eficacia vinculante (Monereo, 1993: 853-854; Galiana, 1993: 189), el art. 17 de la Carta de Derechos Sociales Fundamentales de los Trabajadores de 1989, que reconoce los derechos de información y consulta.

\subsubsection{Derecho derivado}

En este ámbito hemos de atender, como norma más importante, a la Directiva 2002/14 de 11 de marzo por el que se establece el marco general de referencia relativo a la información consulta de los trabajadores en la UE, que ha sido traspuesta a nuestro derecho interno por la Ley 38/07 de 16 de noviembre. Esta Directiva establece requisitos mínimos comunes para las disposiciones na-

2 Vid. Protocolo n. 2 sobre la aplicación de los principios se subsidiariedad y proporcionalidad-. DUE 16/12/04 C-310/07.

${ }^{3}$ El art. 151 TFUE establece como objetivos en materia de política social los de fomento del empleo, mejora de las condiciones de vida y de trabajo, a fin de conseguir su equiparación por la vía del progreso, la protección social adecuada, el diálogo social y el desarrollo de los recursos humanos para conseguir un nivel de empleo elevado y duradero y la lucha contra las exclusiones. 
cionales en materia de protección de los derechos de información y consulta de los trabajadores sobre la situación económica y laboral que afecta a su lugar de trabajo.

En esta Directiva, se establece en su art. 4.2 que la información y la consulta abarcarán:

a) la información sobre la evolución reciente y la evolución probable de las actividades de la empresa o centro de trabajo y de su situación económica;

b) la información y la consulta sobre la situación, la estructura y la evolución probable del empleo en la empresa o en el centro de trabajo, así como sobre las eventuales medidas preventivas previstas, especialmente en caso de riesgo para el empleo;

c) la información y la consulta sobre las decisiones que pudieran provocar cambios sustanciales en cuanto a la organización del trabajo y a los contratos de trabajo, incluidas las previstas por las disposiciones comunitarias mencionadas en el apartado 1 del artículo 9.

El Reino de España fue condenado en sentencia del Tribunal de Justicia de las Comunidades Europeas de 5 de julio de 2.007 (TJCE 2007, 182) (caso Comisión de las Comunidades Europeas contra España, C-317/06) «al no haber adoptado en el plazo señalado las disposiciones legales, reglamentarias y administrativas necesarias para dar cumplimiento a dicha Directiva».

Por otro lado, existen ámbitos específicos de derechos de información y consulta como en los supuestos de prevención de riesgos, despidos colectivos, sucesión de empresas, comité de empresa europeo, Sociedad Anónima o Cooperativa Europea etc que vienen regulados en una serie de directivas que no se ven afectadas por la Directiva 2002/14 (vid art. 9) ${ }^{4}$.

${ }^{4}$ Prevención de Riesgos

— Directiva 89/391/CEE de prevención de riesgos laborales: arts. 10 y 11 (Traspuesta por la Ley 31/1995)

\section{Reestructuración empresarial}

- Directiva 98159 de 20 de julio de 1998 relativa a la aproximación de las legislaciones de los Estados miembros que se refieren a los despidos colectivos. Regula los derechos de consulta de los representantes de los trabajadores en casos de despidos colectivos y su trasposición en nuestro derecho interno la tenemos, en síntesis, en el art. 51 ET, art. 124 LRJS, RD 1483/12 de 29 de octubre.

- Directiva 2001\23, de 12 de marzo de 2001, relativa al mantenimiento de los derechos de los trabajadores en los casos de traspasos de empresas, centros de actividad o parte de empresas o centros de actividad, en cuya virtud los trabajadores han de ser informados de las razones del traspaso y sus consecuencias. (vid. art. $44 \mathrm{ET}$ ). Ha sido traspuesta a nuestro derecho interno por la Ley 12/01 de 9 de julio. 


\subsubsection{La Directiva Marco 2002/14 en materia de información y consulta y el derecho}

Analizaremos ahora, brevemente, algunas cuestiones relativas a la filosofía de la flexiguridad que inspira la Directiva; el concepto de información y consulta y el contenido de las mismas en la Directiva y, en fin, en la normativa de trasposición Ley 38/07, que modificó el art. 64 ET, y que conviene no perder de vista.

La Directiva marco en materia de derechos de información y consulta está claramente inspirada en la doctrina de la flexiguridad. En ningún momento del preámbulo se considera que la información y consulta constituyan instrumentos para la mejora de las condiciones de vida y de trabajo de los trabajadores (art. 151 ET), como soportes básicos de la acción sindical, articulada por medio de la negociación colectiva o el conflicto colectivo.

\section{Estructuras empresariales trasnacionales}

- Directiva 2009/38/CE sobre la constitución de un comité de empresa europeo o de un procedimiento de información y consulta a los trabajadores en las empresas y grupos de empresas de dimensión comunitaria, que deroga la anterior Directiva 94/45, que fue traspuesta a nuestro derecho interno por la Ley 10/97 de 24 de abril.

- Directiva 2001/86/CE, de 8 de octubre de 2001, por la que se completa el Estatuto de la Sociedad Anónima Europea en lo que respecta a la implicación de los trabajadores: el Estatuto de la Sociedad Anónima Europea de responsabilidad limitada, aprobado por el Reglamento (CE) n. ${ }^{\circ}$ 2157/2001 del Consejo, se complementa con una directiva indisociable que establece las normas sobre la participación de los trabajadores en decisiones relativas al desarrollo estratégico de la compañía. Traspuesta por la Ley 31/2006.

- Directiva 2003/72/CE, de 22 de julio de 2003, por la que se completa el Estatuto de la sociedad cooperativa europea (Reglamento (CE) n. ${ }^{\circ}$ 1435/2003 del Consejo) en lo que respecta a la implicación de los trabajadores: esta Directiva establece normas relativas a los mecanismos que deben preverse en las sociedades cooperativas europeas para garantizar que los representantes de los trabajadores puedan influir en la gestión de la empresa.

- Directiva 2005/56/CE, de 26 de octubre de 2005, relativa a las fusiones transfronterizas de las sociedades de capital: contiene asimismo normas relativas a la determinación del régimen de participación de los trabajadores que debe aplicarse en la empresa fusionada. Traspuesta por la DF 6 de la Ley 3/09 de 3 de abril.

Modificaciones de las 2009/38/CE y 2002/14/CE, Directivas 98/59/CE y 2001/23/CE (Plazo trasposición 10/10/17)

— Directiva 2015/1794 del Parlamento Europeo y del Consejo, de 6 de octubre de 2015, por la que se modifican las Directivas 2008/94/CE, 2009/38/CE y 2002/14/CE del Parlamento Europeo y del Consejo, y las Directivas 98/59/CE y 2001/23/CE del Consejo, en lo que se refiere a la gente de mar (Texto pertinente a efectos del EEE).

- Las Directivas 2008/94/CE 2009/38/CE y 2002/14/ del Parlamento Europeo y del Consejo, y las Directivas 98/59/CE y 2001/23/CE del Consejo excluyen a determinada gente de mar de su ámbito de aplicación o bien permiten a los Estados miembros excluirla. La Directiva 2015/1794 suprime las exclusiones citadas. 
En efecto los considerandos 7 a 9 de la Directiva nos hablan de objetivos como "reforzar el diálogo social y fomentar relaciones de confianza mutua en la empresa a fin de favorecer la prevención de los riesgos, flexibilizar la organización del trabajo y facilitar el acceso de los trabajadores a la formación dentro de la empresa en un marco de seguridad, concienciar a los trabajadores acerca de las necesidades de adaptación, aumentar la disponibilidad de los trabajadores para adoptar medidas y emprender acciones destinadas a reforzar sus posibilidades de empleo, promover la participación de los trabajadores en la marcha y el futuro de la empresa y fortalecer la competitividad de ésta».

En el marco de la flexiguridad, obviamente, los derechos de información y consulta cobran especial relevancia en los momentos previos a las crisis empresariales cuando el empleo en la empresa pueda estar amenazado (Considerando $8 .^{\circ}$ de la Directiva) y por ello se conciben a información y la consulta como una condición previa para el éxito de los procesos de reestructuración y adaptación de las empresas a las nuevas condiciones inducidas por la globalización de la economía.

Por tanto, la información y consulta no se conciben desde la perspectiva de la actividad sindical para mejorar las condiciones de vida y de trabajo (objetivo previsto en el art. 151 TFUE) sino desde la perspectiva de la flexiguridad, como instrumentos para lograr el éxito de la adaptación de la empresa a la coyuntura económica, lo que comporta una opción y un enfoque netamente liberal del conflicto, que contribuye a explicar muchas de las cuestiones que nos plantearemos a lo largo de las siguientes líneas.

\section{A) Concepto de información y CONSUlta}

El art. 2 f) de la directiva define «información» como la transmisión de datos por el empresario a los representantes de los trabajadores para que puedan tener conocimiento del tema tratado y examinarlo.

$\mathrm{El}$ art. 2.g) directiva define "consulta» como el intercambio de opiniones y la apertura de un diálogo entre los representantes de los trabajadores y el empresario.

El art. 64 ET dispone que se entiende por información la transmisión de datos por el empresario al comité de empresa, a fin de que este tenga conocimiento de una cuestión determinada y pueda proceder a su examen.

Por consulta se entiende el intercambio de opiniones y la apertura de un diálogo entre el empresario y el comité de empresa sobre una cuestión determinada, incluyendo, en su caso, la emisión de informe previo por parte del mismo.

Como vemos en derecho interno la consulta añade el informe en determinados casos, que podemos observar en el art. 64.5 ET, que establece que: 
"El comité de empresa tendrá derecho a emitir informe, con carácter previo a la ejecución por parte del empresario de las decisiones adoptadas por este, sobre las siguientes cuestiones: a) Las reestructuraciones de plantilla y ceses totales o parciales, definitivos o temporales, de aquella.

b) Las reducciones de jornada.

c) El traslado total o parcial de las instalaciones.

d) Los procesos de fusión, absorción o modificación del estatus jurídico de la empresa que impliquen cualquier incidencia que pueda afectar al volumen de empleo.

e) Los planes de formación profesional en la empresa.

f) La implantación y revisión de sistemas de organización y control del trabajo, estudios de tiempos, establecimiento de sistemas de primas e incentivos y valoración de puestos de trabajo.

En este punto hay que destacar que estos informes previos no vienen condicionados por unos umbrales de afectación, como sí impone el derecho de consulta previsto en los art. 41 y 47 ET. Tampoco el derecho de consulta, en la directiva 2002/14, viene condicionado, a diferencia de lo que ocurre con la Directiva 98/59 a unos umbrales de afectación.

Por ello, podemos concluir — con otros autores (Álvarez del Cuvillo, 2012: 109) - que las medidas preventivas, las decisiones sobre cambios sustanciales de organización del trabajo y contratos no han de ser colectivas para originar el derecho a consulta e informe. Basta que se afecte a un contrato y se trata de decisiones que no sólo son de despido colectivo y transmisión de empresas (art. 9.1); sino que son cualquier otra decisión que suponga cambios sustanciales en la organización y en los contratos, entre las que cabría incluir todas las del art. 64.5 ET.

\section{B) Momento, FORMA Y CONTENIDO APROPIADOS}

El art. 4. Directiva dispone:

3. La información se facilitará en un momento, de una manera y con un contenido apropiados, de tal modo que, en particular, permita a los representantes de los trabajadores proceder a un examen adecuado y preparar, en su caso, la consulta.

4. La consulta se efectuará:

a) en un momento, de una manera y con un contenido apropiados;

b) al nivel pertinente de dirección y de representación, en función del tema tratado;

c) con arreglo a las informaciones proporcionadas por el empresario, de conformidad con la letra f) del artículo 2, y al dictamen que los representantes de los trabajadores tienen derecho a formular;

d) de tal modo que permita a los representantes de los trabajadores reunirse con el empresario y obtener una respuesta justificada a su eventual dictamen;

e) con el fin de llegar a un acuerdo sobre las decisiones que se encuentren dentro de las potestades del empresario mencionadas en la letra c) del apartado 2. (decisiones que pudieran provocar cambios sustanciales en cuanto a la organización del trabajo y a los 
contratos de trabajo, incluidas las previstas por las disposiciones comunitarias mencionadas en el apartado 1 del artículo 9.

Como tendremos ocasión de examinar, la obligación de efectuar la consulta en el nivel pertinente de dirección y de representación, en función del tema tratado, presenta numerosos problemas en nuestro derecho interno, por varias razones que podemos sintetizar como sigue:

- la falta de regulación de los grupos de empresas como ámbito apto para la información y consulta, cuando se regulan ya en otros ámbitos, como significativamente es el de negociación colectiva (art. 87 ET)

- la referencia a los centros de trabajo de la información en los casos del art. 64 ET y la fijación del ámbito de la empresa para originar derechos de información y consulta en otros supuestos (ej. art. 41 MSCT)

- el desfase de la regulación de la representación sindical en la empresas, que sigue anclada en el modelo fordista, con empresas o centros de 250 trabajadores, y la realidad social, donde veremos que a 1 de enero de $2015^{5}$, las empresas que en España tenían 20 o más trabajadores representaron el 4,3\% del total, por lo que la representación sindical en la empresa ha pasado a ser algo residual.

El principal problema de la información y consulta en su contenido viene siendo el de considerar el mismo desde una perspectiva finalista (numerus apertus), que abarque todo lo necesario para que los RLT realicen sus funciones; o bien desde una perspectiva restrictiva (numerus clausus), que se limite estrictamente a aquello que la ley dispone, mejorable, eso sí, por Convenio Colectivo.

Como tendremos ocasión de comprobar algunos pasajes del ET (art. 64), pero sobre todo, la reiterada doctrina del TS (entre muchas, la STS 17 de enero de 2012, RJ 2012/4969) se ha decantado de forma evidente por la opción del numerus clausus.

Ello, a pesar de que tanto el art. 64.6 ET y el art. 4.4 de la Directiva hablan de que la información y consulta han de facilitarse en un momento, de una manera y con un contenido "adecuados». La cuestión por tanto, radica en si es compatible el momento, manera y contenido adecuados de que nos habla el art. 4.4 de la Directiva con la doctrina del numerus clausus que sostiene el TS.

Para terminar, hay que valorar positivamente el contenido de la información y consulta previsto en el art. 64 ET en comparación con el mínimo que establece la Directiva, pues claramente lo mejora, como puede observarse con facilidad en el cuadro comparativo siguiente:

\footnotetext{
5 Pueden consultarse los datos en: http://www.ine.es/prensa/np924.pdf
} 


\begin{tabular}{|c|c|}
\hline DIRECTIVA 2002/14 & ESTATUTO (RDL 2/15) \\
\hline \multicolumn{2}{|c|}{ ACTIVIDADES Y SITUACIÓN ECONÓMICA DE LA EMPRESA } \\
\hline \multirow{5}{*}{$\begin{array}{l}\text { Art. 4. 2. La información y la } \\
\text { consulta abarcarán: } \\
\text { a) la información sobre la evo- } \\
\text { lución reciente y la evolución } \\
\text { probable de las actividades de la } \\
\text { empresa o centro de trabajo y de } \\
\text { su situación económica }\end{array}$} & Art. 64.2 \\
\hline & a) Sobre la evolución general del sector económico a que pertenece \\
\hline & $\begin{array}{l}\text { b) Sobre la situación económica de la empresa y la evolución re- } \\
\text { ciente y probable de sus actividades, incluidas las actuaciones } \\
\text { medioambientales que tengan repercusión directa en el empleo, } \\
\text { así como sobre la producción y ventas, incluido el programa de } \\
\text { producción. }\end{array}$ \\
\hline & $\begin{array}{l}\text { Art. } 64.44 \text {. El comité de empresa, con la periodicidad que proceda } \\
\text { en cada caso, tendrá derecho a: }\end{array}$ \\
\hline & $\begin{array}{l}\text { a) Conocer el balance, la cuenta de resultados, la memoria y, en el } \\
\text { caso de que la empresa revista la forma de sociedad por acciones } \\
\text { o participaciones, los demás documentos que se den a conocer a } \\
\text { los socios, y en las mismas condiciones que estos. }\end{array}$ \\
\hline
\end{tabular}

EMPLEO Y MEDIDAS QUE LE AFECTEN

art. 64.2.c) Sobre las previsiones del empresario de celebración de nuevos contratos, con indicación del número de estos y de las modalidades y tipos que serán utilizados, incluidos los contratos a tiempo parcial, la realización de horas complementarias por los trabajadores contratados a tiempo parcial y de los supuestos de subcontratación.

4. El comité de empresa, con la periodicidad que proceda en cada caso, tendrá derecho a:

art. 4.2 b) la información y la consulta sobre la situación, la estructura y la evolución probable del empleo en la empresa o en el centro de trabajo, así como sobre las eventuales medidas preventivas previstas, especialmente en caso de riesgo para el empleo;

b) Conocer los modelos de contrato de trabajo escrito que se utilicen en la empresa así como los documentos relativos a la terminación de la relación laboral.

c) Ser informado de todas las sanciones impuestas por faltas muy graves.

Asimismo, el comité de empresa tendrá derecho a recibir la copia básica de los contratos así como la notificación de las prórrogas y de las denuncias correspondientes a los mismos en el plazo de diez días siguientes a que tuvieran lugar.

5. El comité de empresa tendrá derecho a ser informado y consultado sobre la situación y estructura del empleo en la empresa o en el centro de trabajo, así como a ser informado trimestralmente sobre la evolución probable del mismo, incluyendo la consulta cuando se prevean cambios al respecto.

Art. 64.5 ET Igualmente tendrá derecho a ser informado y consultado sobre la adopción de eventuales medidas preventivas, especialmente en caso de riesgo para el empleo. 


\begin{tabular}{|c|c|}
\hline DIRECTIVA 2002/14 & ESTATUTO (RDL 2/15) \\
\hline \multicolumn{2}{|r|}{ CAMBIOS ORGABIZACIÓN Y CONTRATOS } \\
\hline $\begin{array}{l}\text { art. } 4.2 \text { c) la información y la } \\
\text { consulta sobre las decisiones que } \\
\text { pudieran provocar cambios sus- } \\
\text { tanciales en cuanto a la organi- } \\
\text { zación del trabajo y a los con- } \\
\text { tratos de trabajo, incluidas las } \\
\text { previstas por las disposiciones } \\
\text { comunitarias mencionadas en el } \\
\text { apartado } 1 \text { del artículo 9. (Des- } \\
\text { pidos colectivos y transmisión } \\
\text { de empresas) }\end{array}$ & $\begin{array}{l}\text { Art. } 64.5 \text { ET } \\
\text { Asimismo, tendrá derecho a ser informado y consultado sobre todas } \\
\text { las decisiones de la empresa que pudieran provocar cambios relevan- } \\
\text { tes en cuanto a la organización del trabajo y a los contratos de tra- } \\
\text { bajo en la empresa. (...). } \\
\text { El comité de empresa tendrá derecho a emitir informe, con carácter } \\
\text { previo a la ejecución por parte del empresario de las decisiones adop- } \\
\text { tadas por este, sobre las siguientes cuestiones: } \\
\text { a) Las reestructuraciones de plantilla y ceses totales o parciales, defi- } \\
\text { nitivos o temporales, de aquella. } \\
\text { b) Las reducciones de jornada. } \\
\text { c) El traslado total o parcial de las instalaciones. } \\
\text { d) Los procesos de fusión, absorción o modificación del estatus jurí- } \\
\text { dico de la empresa que impliquen cualquier incidencia que pueda } \\
\text { afectar al volumen de empleo. } \\
\text { e) Los planes de formación profesional en la empresa. } \\
\text { f) La implantación y revisión de sistemas de organización y control } \\
\text { del trabajo, estudios de tiempos, establecimiento de sistemas de } \\
\text { primas e incentivos y valoración de puestos de trabajo. }\end{array}$ \\
\hline
\end{tabular}

\subsection{Marco doctrinal en la UE}

Una vez hemos analizado el marco normativo de los derechos de información y consulta en el marco de la UE conviene ahora centrarnos en las problemáticas más comunes que el TJUE ha ido resolviendo sobre los mismos a lo largo del tiempo.

En este sentido, podemos abordar la doctrina del TJUE desde tres grandes enfoques, que son los tres grandes ejes entorno a los que ha girado la casuística comunitaria de los derechos de información y consulta como son:

1) la tensión entre libertad de empresa y derechos de información y consulta y la degradación del contenido «iusfundamental» de los derechos de información y consulta;

2) el marco comunitario de los derechos de información y consulta como un marco de derecho mínimo;

3) el ámbito de aplicación: la empresa, el centro de trabajo y los grupos de empresa. 


\subsubsection{Libertad de empresa y derechos de información y consulta: la degradación del derecho fundamental a la información y consulta}

El TJUE ha considerado, desde antiguo, los derechos de información y consulta como un límite a la libertad de empresa, la cuál en el marco del Derecho de la UE es entendida como un derecho fundamental en toda regla (art. 16 CDFUE). Como tendremos ocasión de comprobar, a pesar de que los derechos de información y consulta también se hallan reconocidos por el art. 27 de la CDFUE, el TJUE se ha esmerado en degradar su iusfundamentalidad y someterlos siempre a los dictados de la libertad de empresa, concibiéndolos más en su faceta de límites de la misma que en su condición de derecho fundamental.

Para ilustrar el discurrir de la doctrina en el marco que acabamos de trazar, empezaremos por de decir que la libertad de empresa se sitúa en el art. 16 de la CDFUE, en su Título II en que desarrolla la Libertad. El derecho a la información y consulta, en contraposición, se ubica en la cabecera del Título IV de la CDFUE, desarrollando el valor de Solidaridad. Hay que tener en cuenta ello, puesto que quizás su más correcto engarce axiológico fuera el de Ciudadanía, en tanto que los derechos de participación significan, en cierta medida, la introducción de la democracia en la empresa, con lo que ello significa de humanización del factor trabajo al acceder a la información y participar, en determinado grado, en la toma de decisiones que pueden afectarle en la prestación de servicios por cuenta ajena ${ }^{6}$.

En esta pugna libertad de empresa vs derechos de información y consulta existe un claro vencedor, que es la libertad de empresa. Esta afirmación se deja sentir en los propios antecedentes de la Directiva 2002/14, donde se dice en el 19. ${ }^{\text {a }}$ que "Este marco general tiene como finalidad asimismo evitar dificultades administrativas, financieras o jurídicas que pudieran obstaculizar la creación y el desarrollo de pequeñas y medianas empresas. Para ello, se debe limitar el ámbito de aplicación de la presente Directiva, a elección de los Estados miembros, a las empresas que empleen al menos a 50 trabajadores o a los centros de trabajo que empleen al menos a 20 trabajadores».

Por tanto, el legislador comunitario percibe, ab initio, el derecho de información o consulta como un «obstáculo» a la creación y desarrollo de las PYMES. Ante tal consideración cabría objetar que —en ningún caso- sería un obstáculo mayor o mas oneroso que el derivado de las obligaciones tributarias, medioambientales o de otra índole similar, que con total naturalidad están asumidas en nuestro entorno jurídico más próximo. La cuestión, pues, es de prioridades.

${ }^{6}$ En parecido sentido: Monereo y Monereo, 2012: 604. 
En este sentido, hay que apuntar que esta concepción del TJUE de determinados derechos fundamentales como «obstáculos» a las libertades económicas es una constante en la doctrina del TJUE, por ejemplo en STJUE 12 junio 2003 Caso Schmidberger (C-112/00), en que un grupo de ecologistas austriacos ejercitan su libertad de expresión y manifestación bloqueando la autopista de Brener, impidiendo la circulación durante horas. El TJUE adopta la doctrina de la proporcionalidad y se atribuye el papel de establecer una ponderación de proporcionalidad entre libertades económicas y derechos fundamentales.

Esta concepción de los derechos fundamentales como obstáculos a las libertades económicas tendrá, por supuesto, su incidencia en los derechos fundamentales sociales.

Así, por ejemplo, en el ámbito de la Seguridad Social, son de destacar las STJCE 7 febrero 1984 Caso Duphar, Asunto C-238/82; y la STJCE 28 abril 1998, Caso Decker (C-120/95). En el primero se plantea el sistema público holandés de lista de medicamentos como obstáculo a la libertad de circulación de mercancías; en el segundo se plantea una regulación luxemburguesa que obligaba a los afiliados a una caja de seguros médicos a adquirir sus gafas en ópticas del propio Estado, lo que se considerará contrario a la libre circulación de mercancías.

En esta línea, el TJUE, en el marco de la Directiva 2001/24 sobre derechos de los pacientes en la asistencia sanitaria transfronteriza, ha considerado que no vulnera la libre prestación de servicios la sujeción a autorización previa en aquellos supuestos de prestaciones en que exista una justificación derivada de la sostenibilidad del sistema público, como sucede en las prestaciones sanitarias hospitalarias. Ejs: STJCe 13 mayo 2003 Caso Müller-Fauré, C-385/99, 12 julio 2001, Caso Smits y Peerbooms, C-157/99, etc.

Esta sumisión de los derechos fundamentales laborales a las libertades económicas, entre las que cuenta la libertad de empresa encuentra su máximo exponente en las conocidas STJCE 11 diciembre 2007; Caso Viking, Asunto C-438/057; y la STJCE 18 diciembre 2007; Caso Laval,

7 En el apartado 3 del fallo, el TJCE concluye:

"El artículo 43 CE debe interpretarse en el sentido de que medidas de conflicto colectivo como las controvertidas en el asunto principal, que tienen como finalidad conseguir que una empresa privada cuyo domicilio social se encuentra situado en un Estado miembro determinado celebre un convenio colectivo de trabajo con un sindicato establecido en ese Estado y aplique las cláusulas previstas por ese convenio a los trabajadores asalariados de una filial de dicha empresa establecida en otro Estado miembro, constituyen restricciones en el sentido de dicho artículo.

Estas restricciones pueden estar justificadas, en principio, por la protección de una razón imperiosa de interés general, como la protección de los trabajadores, siempre que se compruebe que son adecuadas para garantizar la realización del objetivo legitimo perseguido y que no van más allá de lo necesario para lograr este objetivo». 
Asunto C-341/05'; en ambas sentencias se supedita el derecho a promover conflictos colectivos y, por tanto, la libertad sindical, a la «libre circulación de trabajadores».

En este contexto de ponderación recíproca y asimétrica entre libertades económicas y derechos de los trabajadores, el TJCE ya venía reconociendo, mucho antes de la vigencia de la CDFUE, la libertad de empresa como uno de los derechos fundamentales $y$, por tanto un principio general del derecho comunitario respecto de los cuales el propio TJCE aseguraba el respeto. Así lo podemos comprobar en la STJCE 7 febrero 1985, C-240/83, Asunto ADHBU, en que el TJUE considera la libertad de empresa como un derecho fundamental (F.9):

hay que recordar que los principios de libre circulación de mercancías y libre competencia, así como el libre ejercicio del comercio, en tanto que derechos fundamentales, constituyen principios generales del derecho comunitario respecto de los que el TJCE aseguro su respeto.

En el mismo sentido, la STJCE 5 octubre 1994, C-280/93, Asunto RFA el TJUE considera la libertad de empresa como derecho fundamental (F.78):

tanto el derecho de propiedad como el libre ejercicio de una actividad profesional forman parte de los principios generales del Derecho comunitario. No obstante, estos principios no constituyen prerrogativas absolutas, sino que deben tomarse en consideración en relación con su función en la sociedad. Por consiguiente, pueden imponerse restricciones al derecho de propiedad y al libre ejercicio de una actividad profesional en especial, en el marco de una organización común de mercados, siempre y cuando estas restricciones respondan efectivamente a objetivos de interés general perseguidos por la Comunidad y no constituyan, habida cuenta del objetivo perseguido, una intervención desmesurada e intolerable que afecte a la propia esencia de

${ }^{8}$ En esta resolución el TJCE concluye: $11 .^{\circ}$ Los artículos 49 CE y 3 de la Directiva 96/71/ CE del Parlamento Europeo y del Consejo, de 16 de diciembre de 1996, sobre el desplazamiento de trabajadores efectuado en el marco de una prestación de servicios, deben interpretarse en el sentido de que se oponen a que, en un Estado miembro en el que las condiciones de trabajo y empleo relativas a las materias contempladas en el artículo 3, apartado 1, párrafo primero, letras a) a g), de esta Directiva se encuentran en disposiciones legales, excepto las cuantias de salario minimo, una organización sindical pueda intentar obligar, mediante una medida de conflicto colectivo consistente en un bloqueo de las obras, como la controvertida en el asunto principal, a un prestador de servicios establecido en otro Estado miembro a iniciar con ella una negociación sobre las cuantías del salario que deben abonarse a los trabajadores desplazados y a adherirse a un convenio colectivo cuyas cláusulas establecen, para algunas de estas materias, condiciones más favorables que las derivadas de las disposiciones legales pertinentes, mientras que otras cláusulas se refieren a materias no previstas en el artículo 3 de dicha Directiva.

2. ${ }^{\circ}$ Los artículos 49 CE (RCL 1999, 1205 ter) y 50 CE se oponen a que, en un Estado miembro, la prohibición impuesta a las organizaciones sindicales de adoptar medidas de conflicto colectivo con el fin de derogar o modificar un convenio colectivo celebrado por terceros esté supeditada a que las medidas tengan relación con las condiciones de trabajo y empleo a las que se aplique directamente la legislación nacionali. 
los derechos así garantizados (sentencias de 11 de julio de 1989, Schräder, 265/87, Rec. p. 2237, apartado 15; de 13 de julio de 1989, Wachauf, 5/88, Rec. p. 2609, apartado 18, y sentencia Kühn, antes citada, apartado 16).

En todos estos casos y en otros como la STJCE 14 mayo 1974, Caso Nold C. 4/73 y STJE 27 septiembre 1979, Caso Rdidania C-230/78, la libertad de empresa se tuteló como libertad de ejercer una actividad económica; en otros asuntos como la STJCE de 17 de empresa de 1978, Caso SukkerFabriken, C-151/78) se había tutelado como libertad contractual.

El TJUE se ocupó también del contenido de la libertad de empresa -entre otras - en la STJCE 4 octubre 2004, Caso Pflugradt, Asunto C-409/02. En esta resolución trata sobre las facultades de dirección y organización de los empresarios: (F.18) en relación al personal del BCE, respecto del cuál sostiene que al igual que cualquier otra institución o empresa, posee una facultad de dirección en la organización de sus servicios y en la gestión de su personal.

Como institución comunitaria, goza incluso de una amplia facultad de apreciación en la organización de sus servicios y en el destino de su personal con el fin de cumplir sus misiones de interés público. ${ }^{9}$ Por tanto, a lo largo del tiempo, puede imponer una evolución de las relaciones laborales con sus agentes según lo requiera el interés del servicio con el fin de alcanzar una organización eficaz del trabajo y un reparto coherente de las distintas tareas entre los miembros del personal y adaptarse a necesidades cambiantes.

La devaluación del derecho de información y consulta a seguido el mismo camino que el derecho a la libertad sindical que hemos observado en Viking y Laval, pero a diferencia de aquellos supuestos, en que la ponderación desequilibrada entre derechos laborales y libertades económicas supone una victoria de las segundas; en el caso del derecho de información y consulta su degradación a mero principio y su ineficacia horizontal en caso de incumplimiento han sido las herramientas de su devalución.

En este sentido, podemos considerar a efectos ejemplificativos la emblemática STJUE 15 enero 2014, TJCE 2014\6, Caso Association de médiation sociale (ASM). En esta importante resolución se consuma la devaluación del derecho fundamental a la información y consulta de los trabajadores en la empresa a un mero principio no invocable entre particulares cuando la normativa nacional sea contraria al derecho comunitario.

9 Véanse, por analogía, las sentencias del Tribunal de Justicia de 21 de junio de 1984, Lux/ Tribunal de Cuentas, 69/83, Rec. pg. 2447, apartado 17, y de 12 de noviembre de 1996 [TJCE 1996, 214], Ojha/Comisión, C-294/95 P, Rec. pg. I-5863, apartado 40, y las sentencias del Tribunal de Primera Instancia de 6 de noviembre de 1991, Von Bonkewitz-Lindner/Parlamento, T-33/90, Rec. pg. II-1251, apartado 88, y de 9 de junio de 1998, Hick/CES, T-176/97, RecFP pgs. I-A-281 y II-845, apartado 36. 
En la misma, el TJUE concluye que las disposiciones del artículo 27 de la CDFUE, por sí solo o en conjunción con las disposiciones de la Directiva 2002/14, deben interpretarse en el sentido de que, cuando una disposición nacional de transposición de esa Directiva, como el artículo L. 1111-3 del Código de trabajo francés, es incompatible con el Derecho de la Unión, ese artículo de la Carta no puede ser invocado en un litigio entre particulares para excluir la aplicación de esa disposición nacional.

Esta sentencia tiene un doble efecto devaluador de su condición de derecho fundamental que conviene no perder de vista:

— Relega el art. 27 CDFUE a la condición de principio: el art. 52.5 CDFUE establece que "Las disposiciones de la CDFUE que contengan principios podrán aplicarse mediante actos legislativos y ejecutivos adoptados por las instituciones, órganos y organismos de la Unión, y por actos de los Estados miembros, cuando apliquen el Derecho de la Unión, en el ejercicio de sus competencias respectivas. Sólo podrán alegarse ante un órgano jurisdiccional en lo que se refiere a la interpretación y control de la legalidad de dichos actos».

A partir de este precepto, la distinción entre derechos y principios (art. 51.1 y 52.5 CDFUE), cobra una relevancia insoslayable, pues es tanto como distinguir entre derechos justiciables y meras proclamas programáticas. Los derechos han de respetarse, mientras que los principios deben observarse (art. 51.1 CDFUE). Los principios carecen de justiciabilidad directa, sin normas comunitarias o estatales de desarrollo, en forma parangonable a lo que acontece con nuestros principios rectores de la política social y económica (Capítulo III, Título I, en relación con el art. 53.3 CE). Los principios no dan derechos inmediatos de acciones positivas de las instituciones de la UE o de los Estados miembros $^{10}$. De este redactado, que nos recuerda el art. 53.3 CE, resulta que los principios no pueden fundar acción ante los órganos jurisdiccionales si no existe una normativa de desarrollo y concreción.

La distinción derechos principios, en este punto, nos parece criticable, y puede llevar a la devaluación de los derechos sociales y a la inseguridad en la determinación de qué es derecho y qué principio, lo que ha de trasladarse a la garantía de tutela judicial y seguridad jurídica, en tanto que imprevisibilidad ${ }^{11}$.

En apoyo de esta tesis, cabe decir que de la mera observación del listado de principios y los derechos en la CDFUE revela que los derechos sociales son los

${ }^{10}$ Explicaciones sobre la Carta de los derechos fundamentales. Explicación relativa al art. 52. DO C 303, de 14 de diciembre de 2007.

${ }^{11}$ Así opinan también: Monereo y Monereo, 2014: 1345. 
más afectados, pues los Títulos III (Igualdad) y IV (Solidaridad) son los que mayor número de principios acumulan en relación al número de preceptos: 4/9 y 9/13 respectivamente; frente a los que menos principios tienen: Título I (Dignidad): 0/5, Título VI (Justicia): 0/4, Título IV Ciudadanía 1/9; Título II (Libertades): $4 / 17$

- Impide la eficacia horizontal, entre particulares, del derecho de información y consulta: este segundo efecto supone que el derecho no va a poder invocarse, en caso de incumplimiento por el Estado entre particulares, lo que va a suponer que en el ámbito que se despliega (entre particulares), sea en el que más falta se halla de protección.

Una vez hemos analizado a grandes rasgos el conflicto entre el derecho a la libertad de empresas y el derecho a la información y consulta, pasaremos ahora a examinar el segundo gran enfoque sobre el que se ha centrado la casuística en el ámbito de la UE.

\subsubsection{El marco comunitario de información y consulta como derecho mínimo}

El art. 27 de la CDFUE establece que deberá garantizarse a los trabajadores o a sus representantes, en los niveles adecuados, la información y consulta con suficiente antelación, en los casos y condiciones previstos en el Derecho de la Unión y en las legislaciones y prácticas nacionales.

Por otro lado, la Directiva 2002/14, en su art. 9.3 y 9.4 deja claro la condición de «derecho mínimo» que la directiva tiene respecto de los Derechos nacionales:

«3. La presente Directiva no supondrá menoscabo de otros derechos de información, consulta y participación existentes en las legislaciones nacionales.

4. La aplicación de las disposiciones de la presente Directiva no supondrá motivo suficiente para justificar regresiones respecto de la situación ya existente en los Estados miembros en lo relativo al nivel general de protección de los trabajadores en los ámbitos objeto de la misma».

La condición de derecho de mínimos de los derechos de información y consulta tanto en su marco general (Directiva 2002/14), como en marcos específicos (Directiva 98/59), la podemos encontrar en la STJCE 18 enero 2007. TJCE 2007\14 Caso Confédération générale du travail (CGT) y otros contra Ministère de l'Emploi, de la Cohésion sociale et du Logement. En este caso, se discute sobre una legislación francesa adoptada como remedio a la preocupante situación de desempleo existente en Francia, de forma que la Ley núm. 2005846, de 26 de julio de 2005 (JORF de 27 de julio de 2005, p. 12223), habilitó al Gobierno para adoptar, mediante decreto legislativo, cualquier tipo de me- 
dida dirigida, en particular, a modificar las normas sobre el cómputo del número de trabajadores de plantilla de una empresa, con vistas a la aplicación de las normas de Derecho del trabajo o de obligaciones financieras impuestas por otras normas, con el fin de incentivar con efectos a 22 de junio de 2005 la contratación por las empresas de trabajadores de menos de 26 años. Con ese objetivo, el art. 1 del Decreto Legislativo núm. 2005-892 añadió al referido artículo L. 620-10 el siguiente párrafo:

El trabajador contratado a partir del 22 de junio de 2005, con menos de veintiséis años de edad, no será computado, hasta que cumpla dicha edad, a efectos del cálculo de la plantilla de personal de la empresa en la que trabaja, cualquiera que sea la naturaleza del contrato de trabajo que lo vincula a dicha empresa. Dicha disposición no puede tener por efecto la supresión de un órgano representativo del personal o del mandato de un representante del personal. Las disposiciones del presente párrafo serán aplicables hasta el 31 de diciembre de 2007.

El objetivo de esta normativa, que excluye del cómputo de trabajadores a los menores de 26 ańos de forma temporal es, como se dijo, la promoción del empleo; y el TJUE recuerda que la promoción del empleo constituye un objetivo legítimo de política social y que los Estados miembros disponen de un amplio margen de apreciación para elegir las medidas necesarias para alcanzar los objetivos de su política social ${ }^{12}$.

No obstante, el TJUE considera — con acierto- que el margen de apreciación de que disponen los Estados miembros en materia de política social (y en cualquier otro - cabría añadir-) no puede abocar a que se desustancie la aplicación de un principio fundamental del Derecho comunitario o una disposición de ese mismo ordenamiento jurídico ${ }^{13}$.

Por ello, considera el TJUE, que el art. 3.1 de la Directiva 2002/14 debe interpretarse en el sentido de que se opone a una normativa nacional que excluye, aunque sólo sea temporalmente, a una determinada categoría de trabajadores del cálculo del número de trabajadores empleados a los efectos de dicha disposición.

Ello es así, porque — conforme al TJUE— del decimoctavo considerando de la Directiva se desprende que ésta se propone establecer un marco general que tenga por objetivo el establecimiento de disposiciones mínimas aplicables en toda la Comunidad y no impide a los Estados miembros prever disposiciones más favorables para los trabajadores, pero sí les impide —a pesar

12 Véanse, en particular, las sentencias de 9 de febrero de 1999 [TJCE 1999, 21], SeymourSmith y Pérez, C-167/97, Rec. p. I-623, apartados 71 y 74, así como de 20 de marzo de 2003 [TJCE 2003, 86], Kutz-Bauer, C-187/00, Rec. p. I-2741, apartados 55 y 56.

13 Véanse, en este sentido, las sentencias, antes citadas, Seymour-Smith y Pérez [TJCE 1999, 21], apartado 75, y Kutz-Bauer [TJCE 2003, 86], apartado 57. 
de su amplio margen de apreciación- desustanciar la aplicación de un principio fundamental del Derecho comunitario o una disposición de ese mismo ordenamiento jurídico, de forma que la promoción del empleo no puede dejar fuera del ámbito de protección de la directiva a determinados trabajadores, aunque sea temporalmente.

Esta condición de derecho de mínimos, mejorable por el derecho nacional, también se da respecto de la directiva 98/59 de despidos colectivos, pues en la propia sentencia que estamos comentando (f.44 y 45), el TJUE recuerda que:

...es preciso señalar que de los artículos 1 , apartado 1 , y 5 , de la Directiva 98/59v se desprende que esta Directiva tiene por objeto establecer una protección mínima en materia de información y consulta de los trabajadores en caso de despidos colectivos, aunque los Estados miembros podrán adoptar medidas nacionales más favorables para los referidos trabajadores. Pues bien, debe señalarse que los umbrales previstos en el artículo 1, apartado 1, de la Directiva 98/59 constituyen precisamente esas disposiciones mínimas que los Estados miembros únicamente podrán derogar mediante disposiciones más favorables para los trabajadores.

Esa naturaleza de derecho de mínimos indisponible estatalmente conlleva la conclusión, en el caso que comentamos, de que la Directiva se opone a una normativa nacional que excluye, aunque sólo sea temporalmente, a una determinada categoría de trabajadores del cálculo del número de trabajadores empleados a los efectos de dicha disposición.

La naturaleza de derecho mínimo del derecho de información y consulta, mejorable por los derechos internos, la encontramos también en la STJUE 11 febrero 2010. Caso Holst. Asunto C-405/08. En ella se introduce el matiz de que los mínimos de la Directiva son mejorables por Convenio Colectivo, lo que en el contexto interno actual de prioridad de convenios de empresa y de potenciación de la negociación en dicho ámbito debería ser un incentivo para la inclusión de disposiciones convencionales sobre el particular.

Esta facultad reconocida por el art. 5 Directiva 2002/14 a los Estados miembros, consistente en dejar a los interlocutores sociales el nivel y modalidades de información, es conforme con la jurisprudencia del TJUE según la cual es lícito que éstos dejen, en primer lugar, que los interlocutores sociales lleven a cabo los objetivos de política social que impone una directiva en este ámbito $^{14}$.

14 Véanse en este sentido, en particular, las sentencias de 28 de octubre de 1999 [TJCE 1999, 256], Comisión/Grecia, C-187/98,Rec. p. I-7713, apartado 46, y de 18 de diciembre de 2008 [TJCE 2008, 326], Andersen, C-306/07, Rec. p. I-0000, apartado 25. 
Sin embargo, el TJUE insiste en que dicha facultad no exime a los Estados miembros de la obligación de cerciorarse mediante las apropiadas medidas legales, reglamentarias o administrativas que todos los trabajadores puedan beneficiarse de la protección que les confiere la Directiva 2002/14 en toda su extensión. La garantía estatal debe cubrir todos los casos en que no se garantice de otra manera una protección y, especialmente, cuando la falta de protección se deba al hecho de que los trabajadores afectados no pertenezcan a un sindicato (sentencia Andersen [TJCE 2008, 326], antes citada, apartado 26).

Ello traducido a nuestro ordenamiento interno, supone que los convenios colectivos no pueden suponer diferencias in peius en el mínimo que garantiza la Directiva y el art. 64 del ET.

En esta línea, en el Caso Holst, el TJUE concluye que:

La Directiva 2002/14/CE debe interpretarse en el sentido de que no se opone a que el Derecho interno se adapte a ella mediante un convenio colectivo, cuyo efecto sea que una categoría de trabajadores quede incluida en el ámbito de aplicación de ese convenio aun cuando los trabajadores pertenecientes a dicha categoría no estén afiliados a la organización sindical firmante de dicho convenio y su sector de actividad no esté representado por esa organización, siempre que el convenio colectivo garantice a los trabajadores incluidos en su ámbito de aplicación la protección efectiva de los derechos que les concede la citada Directiva.

Ahora bien, la sentencia llega a una segunda conclusión cuestionable en cuanto a la protección de los representantes de los trabajadores y, a la postre, en cuanto a la acción sindical y la libertad sindical, toda vez que concluye que el art. 7 de la Directiva 2002/14 debe interpretarse en el sentido de que no exige que se conceda a los representantes de los trabajadores una protección reforzada frente al despido. No obstante, cualquier medida adoptada para adaptar el Derecho interno a dicha Directiva, sea mediante ley o mediante convenio colectivo, deberá respetar el nivel mínimo de protección previsto en el citado artículo 7.

En este punto, el TJUE efectúa una interpretación literalista del art. 7 de la Directiva, alejado incluso de la exigencia del efecto útil de la misma y de los estándares marcados por la OIT ${ }^{15}$, puesto que concluye que si bien es cierto que del artículo 7 de la Directiva 2002/14, establece los Estados miembros velarán

15 Artículo 1 Convenio 135 OIT: "Los representantes de los trabajadores en la empresa deberán gozar de protección eficaz contra todo acto que pueda perjudicarlos, incluido el despido por razón de su condición de representantes de los trabajadores, de sus actividades como tales, de su afiliación al sindicato, o de su participación en la actividad sindical, siempre que dichos representantes actúen conforme a las leyes, contratos colectivos u otros acuerdos comunes en vigon. 
por que los representantes de los trabajadores gocen, en el ejercicio de sus funciones, de la protección y las garantías suficientes que les permitan realizar de manera adecuada las tareas que les hayan sido encomendadas, afirma que ni del tenor literal ni del espíritu del artículo citado se desprende en modo alguno que, para ajustarse a las exigencias que establece, sea necesario otorgar a los representantes de los trabajadores una protección reforzada frente al despido.

En este punto se debilita el derecho fundamental a la información y consulta, puesto que la consecuencia de su infracción mediante la forma más grave en la relación laboral — despido- no es el restablecimiento íntegro a la situación anterior (vid. art. 55 LOTC, art. 182 LRJS, art. 55.5 y 68 ET y art. 1 Convenio 135 OIT), sino cualquier otra que sea suficiente y le permita realizar las tareas encomendadas. El TJUE considera que no se aseguraría esa protección efectiva del art. 7 Directiva si se garantizase únicamente a los trabajadores del consejo de empresa que estén afiliados a un sindicato firmante del convenio colectivo del que se trata la posibilidad de que se compruebe que su despido no ha tenido como motivo su condición de representante de los trabajadores o el ejercicio de sus funciones como tal. (F. 65 Caso Holst). En este punto, el TJUE parece considerar suficiente la posibilidad de comprobar que el despido no ha tenido como motivo la condición de representante o el ejercicio de sus funciones, pero sin añadir ninguna protección extra como señaladamente serían en nuestro derecho interno la nulidad, el expediente contradictorio o la prioridad de permanencia (vid. art. $68 \mathrm{ET}$ ).

No parece muy lógico privar a los receptores de la información y consulta de la protección reforzada que el TJUE niega que garantice la directiva si se quiere que esta tenga un efecto útil. Se plantea, en fin, si la inexistencia de protección reforzada a los RLT frente al despido en las legislaciones nacionales puede considerarse como sanción efectiva, disuasoria y proporcional a la gravedad de las infracciones en caso de que se incumplan las obligaciones que emanan de la Directiva.

\subsubsection{Ambito de aplicación: empresa, centro de trabajo, grupos de empresa}

El ámbito de aplicación de las Directivas, en concreto la dicotomía empresa-centro de trabajo y también la cuestión de los grupos de empresa han sido fuente frecuente de conflictos.

En este punto, hay que partir de que el art. 3 de la Directiva 2002/14, dispone que:

1. La presente Directiva será de aplicación, a elección de los Estados miembros:

a) a las empresas que empleen en un Estado miembro al menos a 50 trabajadores; o 
b) a los centros de trabajo que empleen en un Estado miembro al menos a 20 trabajadores. Los Estados miembros determinarán el modo de calcular el número de trabajadores empleados. En el art. 2 se definen el concepto de empresa y centro de trabajo ${ }^{16}$.

Por otro lado, no puede perderse de vista que en el considerando n. ${ }^{\circ} 18$ de la Directiva se sostiene que se debe limitar el ámbito de aplicación de la misma, a elección de los Estados miembros, a las empresas que empleen al menos a 50 trabajadores o a los centros de trabajo que empleen al menos a 20 trabajadores con la finalidad de evitar dificultades administrativas, financieras o jurídicas que pudieran obstaculizar la creación y el desarrollo de pequeñas y medianas empresas.

En fin, en otras Directivas que contienen derechos de información y consulta, los conceptos de centro de trabajo o empresa también son determinantes para fijar su ámbito de aplicación (Vid. art. 1 a) Directiva 98/59; art. 1 Directiva 2001/23).

La importancia del ámbito en que se ha de satisfacer el derecho de información y consulta ha sido una constante en la doctrina del TJUE, como puede advertirse en la STJCE 8 junio 1994, Comisión contra Reino Unido, Asunto C-383/92, en que se condena por incumplimiento a UK por establecer un ámbito de aplicación más reducido que el previsto en la Directiva de despidos colectivos (Directiva 75/129), al no prever la designación de representantes de los trabajadores cuando el empresario no da su conformidad a la designación, al establecer corno àmbito de aplicación de las disposiciones legislativas destinadas a aplicar la mencionada Directiva un ámbito de aplicación más reducido que el previsto por la Directiva, al no obligar al empresario que proyecta realizar despidos colectivos a consultar a los representantes de los trabajadores con el fin de llegar a un acuerdo y en relación con las materias indicadas en la Directiva, y al no establecer sanciones eficaces para el caso de que no se consulte en la forma exigida por la Directiva a los representantes de los trabajadores.

La cuestión de los ámbitos de la información y consulta, lejos de estar pacificada, sigue surgiendo con intensidad en la doctrina más reciente, como tendremos oportunidad de comprobar (Vid. STJUE 13 mayo 2015; Caso Rabal Cañas, Asunto C-392/13).

16 Art. 2 «a) "empresa": las empresas públicas o privadas que ejercen una actividad económica, independientemente de que tengan o no ánimo de lucro, situadas en el territorio de los Estados miembros;

b) "centro de trabajo": una unidad de actividad definida conforme a la legislación y la práctica nacionales, situada en el territorio de un Estado miembro, y en la que se desarrolla una actividad económica de forma continuada con medios humanos y materiales;" 
Partiendo de tales premisas analizaremos ahora las cuestiones más relevantes planteadas por la doctrina del TJUE en torno a los conflictos derivados de la definición del ámbito de aplicación a través de los conceptos de centro de trabajo, empresa y, finalmente, examinaremos a vista de pájaro la problemática de los grupos de empresa en el ámbito de la información y consulta de los RLT.

\section{A) El concepto de centro de trabajo}

El de centro de trabajo ha sido polémico y ha sido examinado en tres ocasiones recientemente por el TJUE: casos USDAW, Lyttle y Rabal Cañas, todos ellos tratan supuestos de despidos colectivos, pero son aplicables al ámbito común de los derechos de información y consulta que traza la Directiva 2002/14, como tendremos ocasión de ver, en especial en el caso Lyttle.

La STJUE 30 abril 2014. Caso USDAW ${ }^{17}$ y Wilson; Asunto C-80/14, analiza un supuesto en que el Employment Tribunal Liverpool y el Employment Tribunal London Central ordenaron el pago de indemnizaciones de protección a favor de varios trabajadores despedidos de Woolworths y de Ethel Austin. No obstante, denegaron su pago a aproximadamente 4.500 antiguos trabajadores debido a que habían trabajado en centros de trabajo con menos de 20 trabajadores y, conforme a la normativa de UK, cada uno de esos centros de trabajo debía considerarse por separado.

El art. 1.1 de la Directiva 98/59 define los despidos colectivos en relación a los centros de trabajo, de forma que se consideran despidos colectivos los que afecten, por ejemplo: para un período de 30 días: —al menos igual a 10 en los centros de trabajo que empleen habitualmente más de 20 y menos de 100 trabajadores. (art. 1.1a) i).

En el caso USDAW se plantea la cuestión de si la obligación de consulta previa resulta aplicable siempre que un empresario tenga la intención de despedir por causas económicas a 20 trabajadores o más durante un período igual o inferior a 90 días, con independencia de los centros de trabajo concretos en que trabajen; o sólo cuando los 20 trabajadores trabajan en un solo centro.

El TJUE recuerda que en su Sentencia Rockfon (TJCE 1995/218) interpretó el concepto de «centro de trabajo» que figura en el artículo 1, apartado 1, párrafo primero, letra a), de la Directiva 98/5, en el sentido de que designa, según las circunstancias, aquella unidad a la que se hallan adscritos los trabajadores afectados por el despido para desempeñar su cometido. A efectos de la definición del concepto de "centro de trabajo» no resulta esencial que dicha unidad disponga de una dirección facultada para efectuar autónomamente despidos colectivos.

17 Union of Shop, Distributive and Allied Workers. 
El TJUE — después de citar sus precedentes - reconoce que es cierto que la interpretación según la cual esta disposición ${ }^{18}$ requeriría que se tomasen en consideración todos los despidos llevados a cabo en todos los centros de trabajo de una empresa aumentaría de manera considerable el número de trabajadores que podrían beneficiarse de la protección de la Directiva 98/59, lo que sería conforme a uno de sus objetivos.

No obstante los intereses de los trabajadores ceden ante la libertad de empresa (equiparar las cargas que la información y consulta suponen para las empresas) y ante la condición de directiva de mínimos que tiene por finalidad garantizar una protección comparable de los derechos de los trabajadores en los diferentes Estados miembros (vid. apartados 61-64 Caso USDAW y apartados 42-45 Caso Lyttle).

El TJUE obvia — a diferencia de la Directiva 2002/14- que los derechos de información y consulta son una carga mayor para las PYMES, que ya están excluidas del ámbito de la Directiva 98/59, por lo que su interpretación es tanto más desproporcionada cuanto mayor sea el tamaño de la empresa.

Partiendo de tales premisas, el TJUE concluye que la Directiva exige que se tomen en consideración los despidos efectuados en cada centro de trabajo considerado por separado. Por ello, el TJUE entiende que es correcta una normativa nacional que establece una obligación de información y consulta de los trabajadores cuando se despide, en un período de 90 días, a al menos 20 trabajadores de un centro de trabajo concreto de una empresa, y no cuando el número acumulado de despidos en todos los centros de trabajo de una empresa, o en algunos de ellos, durante ese mismo período, alcanza o sobrepasa el umbral de 20 trabajadores.

No obstante, hay que apuntar que el TJUE, conforme al art. 5 Directiva otorga la facultad a los Estados miembros de aplicar o de introducir disposiciones legales, reglamentarias o administrativas más favorables para los trabajadores o de permitir o de fomentar la aplicación de disposiciones convencionales más favorables para los trabajadores. Por tanto, sería correcta una legislación nacional que mejorara la protección estableciendo un ámbito de cómputo empresarial, siempre que ello no empeorase los mínimos de la Directiva, como se dirá en Rabal Cañas.

En la sentencia STJUE 13 mayo 2015; Caso Rabal Cañas. Asunto C-392/13. se vuelve a plantear el concepto de "centro de trabajo", esta vez por el Juzgado de lo Social n. 33 de Barcelona.

En este supuesto, cuando se produjo el despido controvertido en el litigio principal, Nexea ejercía una actividad comercial consistente en la prestación

${ }^{18}$ El artículo 1, apartado 1, párrafo primero, letra a), inciso ii), de la Directiva 98/59. 
de servicios de correo híbrido, en dos centros de trabajo situados respectivamente en Madrid y en Barcelona. Si bien ambos centros de trabajo contaban con un único jefe de producción y con una contabilidad y gestión presupuestaria comunes, y desarrollaban funciones esencialmente idénticas, a saber, la impresión, el manipulado y el ensobrado del correo, el centro de Barcelona disponía no obstante de un jefe de centro de trabajo, puesto a la disposición de dicho centro por el de Madrid, encargado de la coordinación del trabajo in situ. El centro de trabajo de Barcelona se abrió con el fin de aumentar la capacidad de Nexea para gestionar el correo de sus clientes y, más concretamente, para la gestión de los encargos de clientes locales de la empresa. Ante tales circunstancias el TJUE considera que el centro de trabajo de Barcelona puede cumplir los criterios enunciados por la jurisprudencia del TJUE sobre centro de trabajo.

En efecto, el TJUE recuerda su lo dicho en la STJUE 15 febrero 2007, Caso Athinaïki Chartopoiïa, Asunto C-270/05 (TJCE 2007, 33) el en que hizo precisiones adicionales sobre el concepto de "centro de trabajo" y declaró, (ap. 27) que a efectos de la aplicación de la Directiva 98/59, puede constituir concretamente un "centro de trabajo", en el marco de una empresa, una entidad diferenciada, que tenga cierta permanencia y estabilidad, que esté adscrita a la ejecución de una o varias tareas determinadas y que disponga de un conjunto de trabajadores, así como de medios técnicos y un grado de estructura organizativa que le permita llevar a cabo esas tareas.

Al utilizar los términos "entidad diferenciada» y "en el marco de una empresa», el Tribunal de Justicia precisó que los conceptos de "empresa" y de "centro de trabajo» son distintos y que el centro de trabajo es, por regla general, una parte de una empresa. No obstante, ello no excluye que el centro de trabajo y la empresa puedan coincidir en aquellos casos en los que la empresa no disponga de varias unidades distintas.

El TJUE continúa diciendo que cuando una «empresa» incluye varias entidades que cumplen los criterios precisados en las Sentencias Rockfon y Athinaïki, el "centro de trabajo» es la entidad a la que se hallan adscritos los trabajadores afectados por el despido para desempeñar su cometido, y son los despidos efectuados en dicha entidad los que han de tomarse en consideración separadamente de los efectuados en otros centros de trabajo de esa misma empresa ${ }^{19}$.

Por ello, considera el TJUE en el Caso Rabal Cañas, que la Directiva se opone a una normativa nacional que introduce, como única unidad de referencia, la empresa y no el centro de trabajo, cuando la aplicación de dicho

19 Véanse, en este sentido, las sentencias Lyttle y otros, C-182/13, EU:C:2015:0000, apartado 33, y USDAW y Wilson, C-80/14, EU:C:2015:291, apartado 52. 
criterio conlleva obstaculizar el procedimiento de información y consulta establecido en los artículos 2 a 4 de esta Directiva, siendo así que, si se utilizase como unidad de referencia el centro de trabajo, los despidos de que se trata deberían calificarse de "despido colectivo" a la luz de la definición que figura en el artículo 1, apartado 1, párrafo primero, letra a), de dicha Directiva.

Ello supondrá que los derechos de información y consulta establecidos en la directiva y que puedan corresponder a las secciones sindicales o RLT de centro de trabajo se verán vulnerados cuando no se negocie con ellas en los casos en que la fijación como unidad de cómputo en la empresa suponga que se prive a las mismas de negociar si se hubieran aplicado los umbrales del art. 51 en el caso de tratarse de un despido en el ámbito de centro de trabajo.

Ej: empresa con 300 trabajadores despide 10 trabajadores en un centro que cuenta con 20 .

La sentencia Rabal Cańas nos lleva a plantearnos, al menos desde el prisma teórico, si es posible la extensión de tal criterio a ámbitos que se hallan fuera de la Directiva 98/59 de despidos colectivos, pero dentro del ámbito de aplicación de la Directiva 2002/14, nos referimos a las modificaciones sustanciales de condiciones de trabajo, reducciones de jornada o suspensiones de contratos de trabajo (art. 41 y 47 ET).

En primer lugar, la Directiva 2002/14 da dos opciones a los Estados:

- Empresas con mínimo 50 trabajadores

- Centro de trabajo con mínimo 20 trabajadores

En segundo lugar, la norma interna —en general- mejora la directiva, pues, optando por el marco de centro de trabajo (no de empresa) el art. 62 ET da derecho a información y consulta a los centros que cuenten con más de 10 y menos de 20 y a los centros de más de 6 y menos de 10, en este último caso, si hay acuerdo mayoritario de los trabajadores.

En tercer lugar, el art. 41 y el art47 fijan sus umbrales en relación al tamaño de la empresa, no del centro de trabajo, a diferencia del art. 62 ET. Por esa razón, hay casos de MSCT, suspensiones o reducciones, en que en los centros de trabajo de menos de 20 trabajadores no gozan de derecho de consulta por razón del tamaño de la empresa. Por ejemplo: MSCT de 10 trabajadores en el centro de trabajo de 20 en una empresa de 300: conforme al art. 41 no hay derecho de consulta.

Esto conlleva que, conforme al art 4.2c) Directiva - que es un mínimo indisponible- en estos casos debería haber derecho de información y de consulta previa y conforme al art 41 ET no hay consulta. 
Es aquí donde entendemos que la doctrina Rabal sería extrapolable; pues en estos casos podríamos sostener que "la Directiva 2002/14, se opone una normativa nacional que introduzca como única unidad de referencia la empresa (art. 41 ET) y no el centro, cuando la aplicación de este criterio comporte obstaculizar el procedimiento de información y consulta establecido en el art. 4.2c) de la Directiva 2002/14».

La única solución es defender que en estos supuestos el art. 64.5 ET (información y consulta en casos de Cambios relevantes en cuanto a la organización del trabajo y los Contratos de trabajo) cubre los casos en que, existiendo centros de trabajo de al menos 20 trabajadores que se ven afectados por MSCT pero que conforme al art. 41 no tienen derecho a consulta por razón del tamaño de la empresa, lo tienen por la vía del art. 64.5 ET.

Lo hasta aquí dicho viene reforzado por la STJUE 13 mayo 2015, Caso Lyttle, Asunto C-182/13, vuelve a plantearse el concepto de "centro de trabajo» y en este supuesto se acude a la Directiva 2002/14 para corroborar la interpretación del centro en contraposición a la empresa, como unidad determinante del cómputo de los umbrales necesarios para activar los derechos de información y consulta.

En este caso se trata de trabajadores que trabajan para la sociedad Bonmarché en cuatro tiendas diferentes. Éstas se encontraban en ciudades distintas, a saber, Lurgan, Banbridge, Omagh y Belfast, y en cada una de ellas trabajaban menos de 20 trabajadores. Las demandantes en el litigio principal fueron despedidas, junto con otros trabajadores, el 12 de marzo de 2012. El proceso de despido no fue precedido de ningún procedimiento de consulta en el sentido de la Directiva 98/59.

Se plantea la cuestión de si el artículo 1, apartado 1, párrafo primero, letra a), inciso ii), de la Directiva 98/59 debe interpretarse en el sentido de que se opone a una normativa nacional que establece una obligación de información y consulta de los trabajadores cuando se despide, en un período de 90 días, a al menos 20 trabajadores de un centro de trabajo concreto de una empresa, y no cuando el número acumulado de despidos en todos los centros de trabajo de una empresa, o en algunos de ellos, durante ese mismo período alcanza o sobrepasa el umbral de 20 trabajadores.

En el caso Lyttle, el TJUE realiza una interpretación prácticamente idéntica al caso USDAW y Wilson sobre la consideración del carácter de mínimos de la Directiva y la imposibilidad de su interpretación "pro operario» en el sentido de hubiera de considerarse que los despidos han de computarse en todos los centros y no en uno solo. Ahora bien, es de destacar que en el caso Lyttle el TJUE hace mención al concepto de centro de la Directiva marco de información 2002/14, para concluir que la definición que figura en el artículo 1, apartado 1, párrafo primero, letra a), inciso i), y letra a), inciso ii), de la Directiva 98/59 exige que se 
tomen en consideración los despidos efectuados en cada centro de trabajo considerado por separado. Por ello, podemos concluir que los conceptos de centro de trabajo en la Directiva 98/59 y en la Directiva 2002/14 son coincidentes ${ }^{20}$.

En efecto, al decir del TJUE, tal interpretación del concepto «centro de trabajo", se ve corroborada por las disposiciones de la Directiva 2002/14/CE cuyo artículo 2, letras a) y b), establece igualmente una clara distinción entre los conceptos de "empresa» y de "centro de trabajo». Por ello, concluye que la Directiva no se opone a una normativa nacional que stablece una obligación de información y consulta de los trabajadores cuando se despide, en un período de 90 días, a al menos 20 trabajadores de un centro de trabajo concreto de una empresa, y no cuando el número acumulado de despidos en todos los centros de trabajo de una empresa, o en algunos de ellos, durante ese mismo período alcanza o sobrepasa el umbral de 20 trabajadores.

El impacto de esta doctrina sobre centro de trabajo que acabamos de exponer en nuestro derecho interno de derechos de información y consulta en contextos no patológicos (despidos colectivos, MSCT; etc), es más bien modesto, si partimos de la base de que — en general — nuestro derecho interno mejora en cuanto a ámbitos aplicativos la Directiva 2002/14. No obstante ello, creemos oportuno hacer algunas consideraciones.

En efecto, Directiva 2002/14 se aplica a Empresas de al menos 50 o Centros de al menos 20 trabajadores, mientras La normativa espańola, en el caso de delegados de personal se aplica a centros de menos de 50 y más de 10 o más de 6 y hasta 10 si hay decisión mayoritaria, siempre referido al centro de trabajo (art. 62 ET), por lo que hay derechos de consulta en centros con menos de 20 y mas de 10 y en los de más 6 y hasta 10 si hay decisión mayoritaria, lo que supone una mejora obvia de la Directiva.

En este sentido, no hay que olvidar que el TS considera que el art. 62 ET, al hablar de la representación de los trabajadores en «la empresa o centro de trabajo» que tenga menos de 50 y más de 10 trabajadores, se refiere a centros de trabajo y sólo a empresas cuando las mismas tienen un solo centro ${ }^{21}$.

20 El art. 2b) de la Directiva 2002/14 define "centro de trabajo»: «una unidad de actividad definida conforme a la legislación y la práctica nacionales, situada en el territorio de un Estado miembro, y en la que se desarrolla una actividad económica de forma continuada con medios humanos y materiales; en cambio la Directiva 98/59 no contiene definición alguna de centro de trabajo».

${ }^{21}$ STS 20 febrero 2008, RJ 2008/1901 La circunscripción electoral afirmábamos, con cita de la sentencia de 18/06/93 (RJ 1993, 4764) [rec. 1576/91], que el centro de trabajo constituye —art. 63.1 ET (RCL 1995, 997) — la regla general de unidad electoral, con la única excepción del supuesto previsto en el art. 63.2 ET; debiendo entenderse por tal - centro de trabajola «unidad productiva, con organización específica y funcionamiento autónomo, aún no siendo independiente del conjunto de la empresa, y que tiene efectos y repercusiones especificas en el ámbito laboral» (STS 17/09/04 [RJ 2004, 8238] —rco 81/03-). 
En principio, por tanto, la normativa espańola mejora la Directiva, pues la Directiva se aplica en Espańa a los centros de menos de 20 trabajadores que tengan delegado de personal.

Sin embargo no dejan de producirse efectos sorprendentes que exigen reflexión, sobre todo sobre la incidencia que la normativa comunitaria y la nacional sobre representación suponen a la hora de propiciar el "pitufeo de centros", situándolos siempre por debajo de los umbrales a fin de evitarse los derechos de información y consulta y el impacto que ello tiene en la libertad sindical y en los derechos de información y consulta y los representantes de los trabajadores.

Ejemplos:

Empresas de 100 con 20 centros de 5: no hay d. ${ }^{\circ}$ información

Empresa de 6 trabajadores en un centro: hay d. ${ }^{o}$ información

Ello podría ser uno - entre otros muchos - de los factores que explicase un rasgo característico de la estructura empresarial en Espańa, como es el elevado volumen de pequeñas empresas. Así, en torno al 97,7 \% de las empresas en 2010 tiene menos de 50 trabajadores asalariados, concentrándose la mayor parte en el tramo de menor tamaño (menos de 10 trabajadores).

Cabe señalar además que este segmento de microempresas ha aumentado su peso relativo a lo largo de la década 2000-2010, hasta concentrar el $87 \%$ del total de empresas al final de la misma ${ }^{22}$.

Esta tendencia no hace sino incrementarse, pues a 1 de enero de 2015.23 1,75 millones de empresas (55\% del total) no emplearon a ningún asalariado.

899.802 empresas $(28,2 \%$ del total) tenían uno o dos empleados.

El 83,3 \% de las empresas tenían dos o menos asalariados.

"No cabe desconocer, no obstante, que tanto el art. 62.1 el Estatuto, como otros muchos preceptos de dicha Ley y de la normativa de desarrollo, aluden disyuntivamente a "la empresa o centro de trabajo". Pero... una interpretación lógica y sistemática de la expresión... lleva a la conclusión de que la norma utiliza la conjunción disyuntiva en función del último significado [equivalencia] y no del primero [alternativa]... Lo que el precepto pretende en definitiva al citar ambos términos, es distinguir entre las empresas de estructura u organización funcional simple, entendiendo por tales aquellas en que la empresa... asienta físicamente su actividad sobre un único centro de trabajo, y las de estructura mas compleja o múltiple, que la desarrollan en varios centros. Para las primeras, la expresión "empresa o centro de trabajo", denota equivalencia... Para las de organización compleja o múltiple, donde tal equivalencia no es posible, no opera ya la disyuntiva y el precepto establece el centro de trabajo como única unidad electoral, sin otorgar ninguna facultad de opción a los promotores»

${ }^{22}$ Estudios de la fundación 1 de Mayo: La negociación colectiva y la información económica en España.

${ }^{23}$ Pueden consultarse los datos en: http://www.ine.es/prensa/np924.pdf 
Considerando sólo a las empresas con asalariados, las que tenían 20 o más trabajadores representaron el 4,3\% del total.

Todo ello debería suponer una profunda reflexión sobre la adaptación de las normas sobre información y consulta a la realidad social, posibilitando la flexibilidad sindical en la determinación de los ámbitos de constitución de las secciones sindicales y propiciando reformas normativas que acercaran el sindicato a las PYMES.

A este respecto, en materia de flexibilización del rigorismo interpretativo que viene caracterizando la doctrina del TS en materia de ámbito de secciones sindicales, no puede dejar de citarse la doctrina reciente, expresada en la reciente STS 21/06/2016, Rec 182/15, donde se resume la evolución doctrinal sobre constitución de secciones sindicales en ámbitos de empresa o centro de trabajo, que inicia en una cuarta fase la STS 18 julio 2014 (Ponente: Manuel Ramón Alarcón Caracuel).

\section{a) RESUMEN DE LA EVOluCión DoCTRINAL EN LA MATERIA}

Primera fase. - considera posible tomar como referencia la empresa en su conjunto para cumplir el requisito de ese número de trabajadores - más de 250 - necesario para poder tener Delegados Sindicales de los contemplados en la LOLS. Así, por ejemplo, se afirma en las SSTS 15 julio 1996 y 28 noviembre 1997 (rec. 3432/1995 y 1092/1997).

Segunda fase.- Matizando esa premisa, en años posteriores se va precisando que la posibilidad de acudir a la empresa o al centro de trabajo no es algo que queda al arbitrio del Sindicato sino que ello está en función de los órganos de representación de los trabajadores para ejercer su derecho de representación en la empresa. Debe ser el precepto orgánico que desarrolla el derecho fundamental de sindicación, no la posible norma colectiva que llegue a existir en orden a la más acabada configuración de tal derecho, el que sustente la tutela judicial del mismo, sin que, como es obvio, pueda acudirse al llamado espigueo de normas para conseguir la pretendida representación sindical.

La STS de 10 de noviembre de 1998 (rec. 2123/1998), manteniendo criterio semejante a la STS de 21 noviembre 1994 (rec. 3191/1993), abandona expresamente la tesis contenida en las citadas sentencias de 1996 y 1997 . Concluye que se ha de vincular el artículo 10.1 LOLS «a los criterios y modos de participación de los trabajadores en la empresa». La posibilidad de acudir a la empresa o al centro de trabajo "está en función de los órganos de representación de los trabajadores para ejercer su derecho de participación en la empresa; articulo $4.1 \mathrm{~g}$ y $61 \mathrm{del}$ Estatuto de los Trabajadores, es decir que hay que atenerse a lo dispuesto en el artículo 63 de este Texto Legal». 
En esta línea, la STS 18 noviembre 2005 (rec. 32/2005) razona que el requisito de 250 trabajadores para que la sección sindical sea representada por un delegado sindical está referido al centro de trabajo. Conforme allí se explica, la posibilidad de optar entre la empresa o el centro de trabajo al efecto de que se trata "no es algo que quede al arbitrio del sindicato, sino que ello está en función de los órganos de representación de los trabajadores para ejercer su derecho de participación en la empresa», de modo que habrá de acudirse al ámbito de la representación unitaria existente con arreglo a lo que dispone el artículo 63 del Estatuto de los Trabajadores.

En el mismo sentido pueden verse las SSTS 9 de junio de 2005 (recurso 132/2004), 14 de julio de 2006 (recurso 5111/2004), 14 de febrero de 2007 (recurso 4477/2005), 26 de octubre de 2007 (recurso 42/2007) o 14 de marzo de 2014 (rec. 119/2013). También: STS 9 junio 2005 (rec. 132/2004) o STS 24 noviembre 2009 (rec. 36/2009).

Tercera fase.- De conformidad con lo expuesto, diversas sentencias insistieron en la idea del paralelismo entre la representación unitaria y la representación sindical, de tal manera que si la representación unitaria toma como referencia el centro de trabajo, la Sección Sindical de Empresa y sus Delegados Sindicales también deben tomar esa referencia y no el conjunto de la empresa; salvo en un caso en que, precisamente, lo que exista sea un Comité de Empresa conjunto de ámbito provincial en cuyo supuesto —claramente excepcional- sí cabe tomar esa referencia superior.

Ejemplos: STS 30 abril 2012 (rec. 47/2011), STS 14 marzo 2014 (rec. 119/2013), (TS 13-6-2001, R. 1564/2000)].

Cuarta fase.- Un punto de inflexión surge cuando el Pleno de esta Sala Cuarta aprueba su STS 18 julio 2014 (rec. 91/2013), revisando el criterio que se venía manteniendo por las sentencias anteriores. Considera que la determinación del ámbito de la Sección Sindical corresponde definirlo al propio Sindicato, como facultad de autoorganización interna incluida en el contenido de su derecho fundamental de libertad sindical ex art. 28.1 de la CE. La opción a la que se refiere el artículo 10.1 LOLS entre nombrar delegados sindicales a nivel de empresa o de centro de trabajo pertenece al sindicato en cuestión como titular del derecho de libertad sindical.

En definitiva, corrigiendo nuestra doctrina anterior, declaramos que la opción que se ofrece en el art. 10.1 de la LOLS entre nombrar los Delegados Sindicales a nivel de empresa o de centro de trabajo pertenece al sindicato en cuestión como titular del derecho de libertad sindical. Y, si ha optado por el nivel de empresa, la aplicación de la escala del artículo 68 ET para determinar el número de horas sindicales a que tendrá derecho cada Delegado Sindical debe hacerse interpretando que el número de trabajadores a que se refiere cada uno de los niveles de esa escala es el de la empresa en su conjunto y no el de cada uno de sus centros de trabajo. 
Esta doctrina ha sido ya seguida por diversas sentencias como las de 30 de enero de 2015 (rec. 3221/2013) y 23 septiembre 2015 (rec. 253/2014).

Como conclusión: con la doctrina puede paliarse el evidente desfase normativo de la LOLS y el ET, que contrasta con el "pitufeo empresarial», y lograr una cierta adaptación de la organización sindical a dicha realidad.

Ello será particularmente cierto en empresas que cuenten con más de 250 trabajadores, con múltiples centros de trabajo, varios de los cuales no cuenten con representación unitaria en que la Sección sindical podrá constituirse a nivel de empresa y pedir a ese nivel la información. Si tenemos en cuenta que la Directiva 2002/14 impone en su art. 4.4b) que la consulta se lleve a cabo al nivel pertinente de dirección y de representación, en función del tema tratado; no es descabellado concluir que las Secciones sindicales de empresa pueden pedir información referida a la totalidad de la misma, incluidos los centros de trabajo que carecen de representación unitaria.

Sin embargo, lo cierto es que una solución más acorde con la realidad pasaría por la revisión de los criterios de determinación de los ámbitos de representación unitaria y sindical en el ET y la LOLS.

\section{B) Grupos de empresa}

Otro ámbito conflictivo en la doctrina del TJUE, dentro de la fijación del ámbito de los derechos de información y consulta de los representantes de los trabajadores, ha venido definido por los Grupos de empresa. En este caso las Directivas que han sido objeto de conflicto son las que se refieren a dichos grupos pues, sorprendentemente, la Directiva marco 2002/14 no se refiere en momento alguno a los grupos de empresa, más que en el apartado 30 de su preámbulo para recordar que no deben resultar afectados por la misma otros derechos de información y consulta, incluidos los derivados de la Directiva 94/45/CE del Consejo, de 22 de septiembre de 1994, sobre la constitución de un Comité de empresa europeo o de un procedimiento de información y consulta a los trabajadores en las empresas y grupos de empresas de dimensión comunitaria.

En efecto, en Derecho Comunitario los derechos de información y consulta en el ámbito de grupos de empresa vienen mencionados en la Directiva 2009/38/CE sobre la constitución de un comité de empresa europeo o de un procedimiento de información y consulta a los trabajadores en las empresas y grupos de empresas de dimensión comunitaria, que fue traspuesta a nuestro derecho interno por la Ley 10/97 de 24 de abril.

Este silencio de la Directiva 2002/14 sobre el fenómeno de los grupos de empresa ha provocado que su trasposición a nuestro ordenamiento suponga un silencio sobre el particular del art. 64 ET. 
Se constata así como existe una clara asimetría entre el Derecho comunitario y el derecho interno, pues el primero contempla derechos de información y consulta en los supuestos de grupos de empresa de dimensión comunitaria, mientras que en el caso de nuestra normativa interna los derechos de información y consulta (art. 64 ET) no vienen en modo alguno referido a los grupos de empresa. Ello es particularmente llamativo si tenemos en cuenta que el art. 87 ET prevé la negociación colectiva en el ámbito de los grupos.

A la vista de tal panorama, es comprensible que la problemática generada con los grupos de de la Directiva 94/45 — hoy derogada y sustituida por la vigente Directiva 2009/38 sobre la constitución de un comité de empresa europeo o de un procedimiento de información y consulta a los trabajadores en las empresas y grupos de empresas de dimensión comunitaria. No obstante ello, es preciso apuntar que también en el ámbito de la Directiva 98/59 se ha producido algún supuesto conflictivo sobre despidos colectivos, grupos de empresa y ámbito adecuado de la consulta con los RLT.

A grandes rasgos la Directiva 2009/38 y su antecesora prevén que en cada empresa de dimensión comunitaria y en cada grupo de empresas de dimensión comunitaria se constituirá un comité de empresa europeo o un procedimiento de información y consulta a los trabajadores, siempre que se haya formulado una petición en tal sentido de conformidad con el procedimiento previsto en el art. 5.1, a fin de informar y consultar a dichos trabajadores.

En la Directiva que comentamos se define en su art. 2.1b) el «grupo de empresas", como un grupo que comprenda una empresa que ejerce el control y las empresas controladas.

Así mismo define en su art. 2.1c) el «grupo de empresas de dimensión comunitaria» como todo grupo de empresas que cumpla las siguientes condiciones:

—que emplee a 1000 o más trabajadores en los Estados miembros,

- que comprenda al menos dos empresas miembros del grupo en Estados miembros diferentes, $y$

— que al menos una empresa del grupo emplee a 150 o más trabajadores en un Estado miembro y al menos otra de las empresas del grupo emplee a 150 o más trabaja dores en otro Estado miembro.

La doctrina del TJUE en esta materia podemos observarla, entre otras, en las sentencias que pasamos a analizar, en las que el grupo como ámbito de información y consulta se erige en núcleo de la problemática interpretativa. En líneas generales, el TJUE se ha mostrado flexible y generoso respecto de los derechos de información y consulta, aplacando las reticencias empresariales al respecto.

Como tendremos ocasión de comprobar la mayoría de supuestos versan sobre: 
- quién debe proporcionar la información, en particular en los supuestos de empresas cuya dirección central se halla fuera de la UE qué contenido ha de tener esa información.

Así, en la STJCE 29 marzo 2001, C-62/99, Asunto Bertriebsrat del Bofrost, donde el TJUE resuelve que la Directiva 94/45/CE impone a una empresa que pertenece a un grupo de empresas la obligación de proporcionar información a los órganos internos de representación de los trabajadores, aunque aún no conste que la dirección a la que los trabajadores se dirigen es la de una empresa que ejerce el control dentro de un grupo de empresas.

Además, cuando los datos sobre la estructura o la organización de un grupo de empresas formen parte de la información imprescindible para iniciar negociaciones con el objeto de crear un comité de empresa europeo o de establecer un procedimiento de información y consulta transnacional de los trabajadores, corresponderá a cualquier empresa de ese grupo proporcionar los datos de que disponga, o que pueda obtener, a los órganos internos de representación de los trabajadores que lo soliciten. También se podrá exigir la entrega de documentos que precisen y aclaren la información imprescindible para el mismo fin, siempre que esta entrega sea necesaria para que los trabajadores afectados o sus representantes puedan acceder a la información que permita apreciar si tienen derecho a exigir la apertura de negociaciones.

En segundo lugar, la STJCE 14 julio 2004, Asunto Bertriebsrat, C-349/01, el TJUE resuelve que los artículos 4, apartado 1, y 11 de la Directiva 94/45/CE deben interpretarse en el sentido de que los Estados miembros están obligados a imponer a una empresa establecida en su territorio, que deba ser considerada la dirección central de un grupo de empresas de dimensión comunitaria con arreglo a los artículos 2, apartado 1, letra e), y 3, apartado 1, de la Directiva, o la dirección central presunta, en el sentido de su artículo 4, apartado 2, párrafo segundo, la obligación de facilitar a otra empresa del grupo establecida en otro Estado miembro la información que hayan solicitado a ésta los representantes de sus trabajadores, cuando esta última empresa no disponga de tal información y ésta sea imprescindible para el inicio de las negociaciones con objeto de constituir un comité de empresa europeo.

En la STCJCE 13 enero 2004, Caso Nagel, Asunto C-440/00, el TJCE resuelve que:

1. Los artículos 4, apartado 1, y 11, apartado 1, de la Directiva 94/45/CE, deben interpretarse en el sentido de que:

- cuando, en una situación como la que es objeto del procedimiento principal, la dirección central de un grupo de empresas de dimensión comunitaria no esté situada en un Estado miembro, la responsabilidad de ésta de proporcionar a los representantes de los trabajadores la información imprescindible para el inicio de nego- 
ciaciones con el objeto de constituir un comité de empresa europeo incumbe a la dirección central presunta ${ }^{24}$, en el sentido del artículo 4, apartado 2, párrafo segundo, de la Directiva;

- cuando dicha dirección central no ponga a disposición de la dirección central presunta, en el sentido del artículo 4, apartado 2, párrafo segundo, de la Directiva, determinada información, con el fin de constituir un comité de empresa europeo, ésta, para poder cumplir su obligación de información frente a los citados representantes, está obligada a pedir a las demás empresas pertenecientes al grupo y sitas en los Estados miembros y tiene derecho a recibir de ellas la información imprescindible para el inicio de negociaciones con el objeto de constituir este comité;

- las direcciones de las demás empresas del grupo sitas en los Estados miembros tienen la obligación de proporcionar a la dirección central presunta, en el sentido del artículo 4, apartado 2, párrafo segundo, de la Directiva, la citada información de que dispongan o que puedan obtener;

- los Estados miembros afectados velarán por que dichas direcciones proporcionen esta información a la dirección central presunta, en el sentido del artículo 4 , apartado 2, párrafo segundo, de la Directiva.

2. La obligación de información derivada de los artículos 4, apartado 1, y 11 , apartado 1, de la Directiva 94/45 comprende la información sobre la plantilla media de trabajadores y su distribución en los diferentes Estados miembros, los establecimientos de la empresa y las empresas del grupo, y sobre la estructura de la empresa y de las empresas del grupo, así como las denominaciones y direcciones de los representantes de los trabajadores que podrían participar en la formación de una comisión negociadora con arreglo al artículo 5 de la citada Directiva o en la constitución de un comité de empresa europeo, cuando dicha información es imprescindible para el inicio de negociaciones con el objeto de constituir dicho comité.

En la STJCE 13 enero 2004, asunto Gesambetriebsrat der Kühne \&Angel AG \&/Co KG, C-440/00, el TJCE concluye que:

1. Los artículos 4, apartado 1, y 11, apartado 1, de la Directiva 94/45/CE del Consejo, de 22 de septiembre de 1994, sobre la constitución de un comité de empresa europeo o de un procedimiento de información y consulta a los trabajadores en las empresas y grupos de empresas de dimensión comunitaria, deben interpretarse en el sentido de que:

- cuando, en una situación como la que es objeto del procedimiento principal, la dirección central de un grupo de empresas de dimensión comunitaria no esté situada en un Estado miembro, la responsabilidad de ésta de proporcionar a los representantes de los trabajadores la información imprescindible para el inicio de negociaciones con el objeto de constituir un comité de empresa europeo incumbe a la di-

${ }^{24}$ Art. 4.2 Directiva 94/345: «Cuando la dirección central no esté situada en un Estado miembro, asumirá la responsabilidad a que se refiere el apartado 1 el representante de la dirección central en el Estado miembro que, en su caso, se designe.

A falta de tal representante, asumirá dicha responsabilidad la dirección del establecimiento o la dirección central de la empresa del grupo que emplee al mayor número de trabajadores en un Estado miembro». 
rección central presunta, en el sentido del artículo 4, apartado 2, párrafo segundo, de la Directiva;

- cuando dicha dirección central no ponga a disposición de la dirección central presunta, en el sentido del artículo 4, apartado 2, párrafo segundo, de la Directiva, determinada información, con el fin de constituir un comité de empresa europeo, ésta, para poder cumplir su obligación de información frente a los citados representantes, está obligada a pedir a las demás empresas pertenecientes al grupo y sitas en los Estados miembros y tiene derecho a recibir de ellas la información imprescindible para el inicio de negociaciones con el objeto de constituir este comité;

- las direcciones de las demás empresas del grupo sitas en los Estados miembros tienen la obligación de proporcionar a la dirección central presunta, en el sentido del artículo 4, apartado 2, párrafo segundo, de la Directiva, la citada información de que dispongan o que puedan obtener;

- los Estados miembros afectados velarán por que dichas direcciones proporcionen esta información a la dirección central presunta, en el sentido del artículo 4 , apartado 2, párrafo segundo, de la Directiva.

2. La obligación de información derivada de los artículos 4, apartado 1, y 11, apartado 1, de la Directiva 94/45 comprende la información sobre la plantilla media de trabajadores y su distribución en los diferentes Estados miembros, los establecimientos de la empresa y las empresas del grupo, y sobre la estructura de la empresa y de las empresas del grupo, así como las denominaciones y direcciones de los representantes de los trabajadores que podrían participar en la formación de una comisión negociadora con arreglo al artículo 5 de la citada Directiva o en la constitución de un comité de empresa europeo, cuando dicha información es imprescindible para el inicio de negociaciones con el objeto de constituir dicho comité.

En el caso de despidos colectivos en el seno de grupos de empresa, el TJUE considera que las obligaciones de información y consulta, conforme a la Directiva 98/59, han de practicarse en el ámbito de la filial, como también ocurre en nuestro derecho interno, en que el interlocutor es la empresa y no el grupo (vid. art. 51.2 ET y art. 7 RD 1483/12).

Así, por ejemplo en la STJCE 10 septiembre 2009, C-44/08 Asunto Akavan Eritysalojen Kesfuliitto. AEK: información y consulta y grupos de empresas.

En virtud de todo lo expuesto, el Tribunal de Justicia (Sala Cuarta) declara:

1) El artículo 2, apartado 1, de la Directiva 98/59/CE del Consejo, de 20 de julio de 1998, relativa a la aproximación de las legislaciones de los Estados miembros que se refieren a los despidos colectivos, debe interpretarse en el sentido de que la adopción, dentro de un grupo de empresas, de decisiones estratégicas o de cambios de actividades que obliguen al empresario a examinar o a proyectar despidos colectivos genera para dicho empresario la obligación de llevar a cabo consultas con los representantes de los trabajadores.

2) El nacimiento de la obligación del empresario de iniciar consultas sobre los despidos colectivos previstos no depende de que éste pueda proporcionar ya a los representantes de los trabajadores toda la información exigida en el artículo 2, apartado 3, párrafo primero, letra b), de la Directiva 98/59. 
3) El artículo 2, apartado 1, de la Directiva 98/59, en relación con el artículo 2, apartado 4, párrafo primero, de esta misma Directiva, debe interpretarse en el sentido de que, en el caso de un grupo de empresas formado por una sociedad matriz y una o varias filiales, la obligación de llevar a cabo consultas con los representantes de los trabajadores sólo nace, para la filial que tiene la condición de empresario, cuando se identifica dicha filial, en la que pueden realizarse los despidos colectivos.

4) El artículo 2, apartado 1, de la Directiva 98/59, en relación con su artículo 2, apartado 4, debe interpretarse en el sentido de que, en el caso de un grupo de empresas, el procedimiento de consulta debe haber sido concluido por la filial afectada por los despidos colectivos antes de que la citada filial, en su caso siguiendo instrucciones directas de su sociedad matriz, extinga los contratos de los trabajadores afectados por dichos despidos.

\subsection{Conclusiones críticas}

La normativa interna espańola no articula los derechos de información y consulta a nivel de grupo de empresas cuando de trata de información del art. 64 ET (información en situaciones de normalidad empresarial o información "fisiológica») Sí lo hace —en cambio- cuando se trata de información y consulta en materia de despidos colectivos. (art. $4.5 \mathrm{RD} 1483 / 12)^{25}$, lo que revela un claro desfase entre los derechos de información en situaciones de crisis y en situaciones de normalidad.

La novedosa posibilidad de negociar convenios a nivel de grupo de empresas (art. 87 pfo3 ET) no viene acompañada por la regulación —en dicho ámbitode derechos de información y consulta que puedan nutrir la negociación de información necesaria y, por ello, exigible a ese nivel conforme al deber general de negociar con buena fe del art. 89.1 pfo 3 ET. Ello es particularmente relevante cuando la legitimación social para negociar no se atribuye a las representaciones unitarias, sino a las organizaciones sindicales.

La anomia de la normativa espańola en materia de derechos de infomración y consulta a nivel de grupo de empresas internos contrasta con la normativa comunitaria, en que prevé constitución de comités de empresa y articulación de derechos de información y consulta en los grupos de empresa de dimensión comunitaria.

25 Art. 4.5 RD 1483/12: "Cuando la empresa que inicia el procedimiento forme parte de un grupo de empresas, con obligación de formular cuentas consolidadas cuya sociedad dominante tenga su domicilio en España, deberán acompañarse las cuentas anuales e informe de gestión consolidados de la sociedad dominante del grupo debidamente auditadas, en el caso de empresas obligadas a realizar auditorías, durante el periodo señalado en el apartado 2, siempre que existan saldos deudores o acreedores con la empresa que inicia el procedimiento. Si no existiera obligación de formular cuentas consolidadas, además de la documentación económica de la empresa que inicia el procedimiento a que se ha hecho referencia, deberán acompañarse las de las demás empresas del grupo debidamente auditadas, en el caso de empresas obligadas a realizar auditorias, siempre que dichas empresas tengan su domicilio social en España, tengan la misma actividad o pertenezcan al mismo sector de actividad y tengan saldos deudores o acreedores con la empresa que inicia el procedimiento". 
Desde la perspectiva de la libertad de establecimiento (art. 49 TFUE) a cuestionarnos si la existencia de una norma europea que prevé la información y consulta en grupos de empresas de determinado tamaño y estructura (tamaño de 1000 o más trabajadores; una estructura que comprenda al menos dos empresas miembros del grupo, y que al menos dos empresas del grupo empleen a 150 o más trabajadores), y la ausencia de regulación nacional de los derechos de información y consulta en los ámbitos de grupos de empresa intraestatales del mismo tamaño no puede ser un obstáculo a la libertad de establecimiento, y si los derechos nacionales habrían de suplir tal carencia contemplando unos derechos de información y consulta para los grupos de empresas intraestatales, al menos para los del mismo tamańo que el previsto en la Directiva 2009/38.

Tal cuestión se plantea más aún si tenemos en cuenta que — como hemos visto- el propio legislador comunitario considera la información y consulta como una "dificultad administrativa, financiera o jurídica» a la formación de empresas $^{26}$.

Es obvio, desde esa perspectiva, que ante la opción de constituir un grupo de empresas con al menos 1000 trabajadores y al menos 2 empresas con 150 trabajadores a nivel comunitario o a nivel interno estatal; en Espańa se imponen menos "dificultades administrativas, financieras y jurídicas", al no imponer derechos de información y consulta en el nivel de grupos de empresas de tales características que se constituyan dentro de sus fronteras. Ello nos lleva a plantear la cuestión de si la normativa española hace menos atractiva la constitución de grupos de dimensión comunitaria que de grupos de dimensión nacional y afecta, por ello, a la libertad de establecimiento del art. 49 TFUE.

Para terminar, como última cuestión relativa a los grupos, y los derechos de información y consulta, hay que partir de que el TS distingue entre el supuesto de un grupo de empresas ficticio o fraudulento (patológico), caso en el que por tratarse en realidad de una empresa [que no de un grupo], en su ámbito podrían constituirse las secciones sindicales y designarse los delegados sindicales, o exigirse derechos de información y consulta si numéricamente - atendido el número de trabajadores del grupo- es factible, con todos los derechos que la LOLS y el art. 64.

El ET les atribuye; y el caso de que el grupo de empresas (mercantil) no sea reconducible a la unidad empresarial a efectos laborales, supuesto en el que en principio no podría haber secciones sindicales ni delegados sindicales de grupo ni RLT de grupo y, por tanto, no habría derecho — conforme a la normativa in-

26 Punto 19 del Preámbulo de la Directiva 2002/14. 
terna- a derechos de información y consulta en el ámbito del grupo mercantil, salvo mejora por convenio.

A nivel de estrategia sindical puede, por tanto, al, comunicar a las empresas del grupo patológico la creación de una sección sindical con, en su caso, el delegado sindical que conforme a la LOLS le pueda corresponder si todas las empresas del grupo superan el umbral correspondiente de plantilla y, en su caso, la promoción de elecciones sindicales a nivel de grupo y, por qué no, la petición de información y consulta a nivel de grupo y, por tanto, en relación a todos los datos del art. 64 ET, pero no referidos a la empresa empleadora, sino al grupo patológico.

\section{OIT}

Los derechos de audiencia, información y consulta los hallamos regulados en el marco de la OIT en determinados instrumentos de entre los que cabe destacar el Convenio n. ${ }^{\circ} 135$ de 1971 relativo a la protección y facilidades que deben otorgarse a los representantes de los trabajadores en la empresa junto a la Recomendación n. ${ }^{\circ} 143$ sobre los representantes de los trabajadores de 1971.

El Convenio 135 establece tanto las garantías de los representantes de los trabajadores en forma de protección eficaz frente a todo acto que les pueda perjudicar por el ejercicio de su función, incluida la protección frente al despido (art. 1) ${ }^{27}$; como las facilidades que han de otorgarse a los mismos, entre las que se hallan los derechos de información, audiencia, consulta y participación.

En el mismo destaca su art. 2 que establece que «Los representantes de los trabajadores deberán disponer en la empresa de las facilidades apropiadas para permitirles el desempeño rápido y eficaz de sus funciones».

El Art. 5 coordina la representación unitaria y sindical, sin que ésta pueda verse menoscabada por la primera, así como la cooperación entre ambos tipos de representaciones.

Por otro lado, en la Recomendación 143 destaca su punto 16 donde se establece que la empresa debería poner a disposición de los representantes de los trabajadores, en las condiciones y en la medida que podrían determinarse por los métodos de aplicación a que se refiere el párrafo 1 de la presente Recomendación, las facilidades materiales y la información que sean necesarias para el ejercicio de sus funciones.

27 En nuestro derecho interno se plasman fundamentalmente en el art. 68 del ET. 
Como Convenios relacionados con la actividad de los representantes de los trabajadores en la empresa y la libertad sindical, aunque no aludan directamente a los derechos de información, consulta, audiencia o participación, podemos citar los que siguen:

- Convenio n. ${ }^{\circ} 87$ sobre la libertad sindical y la protección del derecho de sindicación

- Convenio n. ${ }^{\circ} 98$ sobre el derecho de sindicación y de negociación colectiva

- Convenio n. ${ }^{\circ} 141$ sobre las organizaciones de trabajadores rurales

- Convenio n. ${ }^{\circ} 151$ sobre las relaciones de trabajo en la administración pública.

Por otro lado, hay que destacar el Convenio 154 de la OIT sobre negociación colectiva. En el mismo se establece el deber de adoptar medidas adecuadas a las condiciones nacionales para fomentar la negociación colectiva y, en lo que aquí interesa, el art. 5.2 d) dispone que la negociación colectiva no resulte obstaculizada por la inexistencia de reglas que rijan su desarrollo o la insuficiencia o el carácter impropio de tales reglas.

En esta línea, la Recomendación n. ${ }^{\circ} 163$ de la OIT es la más precisa en cuanto a la información en materia de negociación colectiva, concretándola en el concepto de «negociación con conocimiento de causa»:

(1) En caso necesario, deberian adoptarse medidas adecuadas a las condiciones nacionales para que las partes dispongan de las informaciones necesarias para poder negociar con conocimiento de causa.

(2) Con este objeto:

(a) a petición de las organizaciones de trabajadores, los empleadores —públicos y privados - deberian proporcionar las informaciones acerca de la situación económica y social de la unidad de negociación y de la empresa en su conjunto que sean necesarias para negociar con conocimiento de causa; si la divulgación de ciertas de esas informaciones pudiese perjudicar a la empresa, su comunicación debería estar sujeta al compromiso de mantener su carácter confidencial en la medida en que esto sea necesario; las informaciones que puedan proporcionarse deberían ser determinadas por acuerdo entre las partes en la negociación colectiva;

(b) las autoridades públicas deberian proporcionar las informaciones necesarias sobre la situación económica y social global del país y de la rama de actividad en cuestión, en la medida en que la difusión de tales informaciones no resulte perjudicial para los intereses nacionales.

También hay que destacar, en fin, la Recomendación 129 de la OIT sobre elementos de la política de comunicación en la empresa, que aunque no está encaminada directamente a la negociación colectiva, constituye un parámetro a considerar en el análisis del contenido de la información. 


\title{
4. Consejo de Europa
}

\author{
Carta Social Europea, Protocolo Adicional de 05/05/1988 (ratificado por \\ España):
}

art. 2 Derecho a información y consulta.1.- Con el fin de garantizar el ejercicio efectivo del derecho de los trabajadores a la información y consulta de la empresa, las Partes se comprometen a tomar o promover medidas que permitan a los trabajadores o a sus representantes, de conformidad con la legislación la práctica nacionales:

a) Ser informados periódica u oportunamente, y en manera comprensible, de la situación económica y financiera de la empresa que les da empleo, quedando entendido que podrá denegarse la divulgación de ciertas informaciones que puedan perjudicar a la empresa o exigirse que se mantengan confidenciales; $y$

b) ser consultados a su debido tiempo acerca de las decisiones previstas que puedan afectar substancialmente a los intereses de los trabajadores y, en particular, acerca de las que puedan tener consecuencias importantes sobre la situción del empleo en la empresa

2.- Las Partes podrán excluir del alcance del párrafo 1 del presente artículo a aquellas empresas que empleen a un número de trabajadores inferior a un minimo determinado por la legislacion o la práctica nacionales.

La Carta Social Europea revisada de 3 de mayo de 1996 (firmada pero no ratificada por Espańa):

Art. 21 "Los trabajadores tienen derecho a la información y a la consulta en el seno de la empresa». ${ }^{28}$

El art. 11 del CEDH y la doctrina del TEDH: el derecho de consulta no se deriva del art. $11 \mathrm{CEDH}$.

STEDH 27 octubre 1975. Caso Sindicato Nacional de la Policía Belga contra Bélgica. TEDH $1975 \backslash 2$ (3 opiniones separadas) 37 Según el artículo 11.1, del Convenio, «toda persona tienen derecho a la libertad de reunión pacífica y a la libertad de

28 España se incorporó al Consejo e Europa el 24/11/1977 y ratificó la versión originaria de la CSE el 29/04/1980 (Instrumento de Ratificación de 29 de abril de 1980, de la CSE, hecha en Turín de 18 de octubre de 1961.Publicado en: «BOE» núm. 153, de 26 de junio de 1980).

La Carta tiene los siguientes Protocolos:

- Protocolo Adicional 5/05/1988: ratificado por España (Instrumento de ratificación de 24 enero 2000)

- Protocolo 21/10/1991: firmado el 21/10/1991; (Instrumento de ratificación 24 de enero de 2000)

- Protocolo 09/11/1995. No ratificado por Espańa

- Carta Social Europea revisada de 03/05/1996: firmada el 23/10/00, pero no ratificada por España. 
asociación, incluido el derecho de fundas con otras personas sindicatos y de afiliarse, a los mismos para la defensa de sus intereses».

$38 \mathrm{La}$ mayoría de la Comisión ha dictaminado que los elementos esenciales de la actividad sindical, entre los que debe incluirse el derecho de consulta, entran dentro del dominio de la precipitada norma.

El Tribunal advierte que el artículo 11.1, presenta la libertad sindical como una forma o aspecto específico de la libertad de asociación; no garantiza ni a los sindicatos, ni a sus miembros un trato específico por parte del Estado y, en concreto, el derecho a ser consultados por éste. No sólo este último derecho no se menciona en el artículo 11.1, sino que tampoco se podría afirmar que los Estados Contratantes lo consagren todos, en principio, en su legislación y práctica internas, ni que el mismo sea imprescindible para el ejercicio eficaz de la libertad sindical. En principio, no constituye un elemento necesariamente inherente a un derecho garantizado por el Convenio, en lo que se diferencia, por ejemplo, del derecho a un Tribunal incluido en el artículo 6 (Sentencia Golder de 21 febrero 1975 (TEDH 1975, 1), serie A, núm. 18, pg. 18, ap. 36).

Por lo demás, las cuestiones relativas a los sindicatos han sido tratadas con mayor detalle en otro convenio elaborado también en el marco del Consejo de Europa: la Carta Social de 18 de octubre de 1961. El artículo 6.1 de dicho instrumento obliga a los Estados Contratantes «a favorecer la consulta paritaria entre trabajadores y patronos». La prudencia de los términos utilizados muestra que la Carta no reconoce un verdadero derecho de consulta; según el artículo 20, un Estado que lo ratifica puede no aceptar el compromiso que resulta de artículo 6.1. Por tanto, no se puede comprender que un derecho de tal naturaleza se derive implícitamente del artículo 11.1, del Convenio de 1950 lo que por lo demás equivaldría a admitir que la Carta de 1961 habría marcado un retroceso en esta materia.

39 El Tribunal no coincide, sin embargo, con la tesis de la minoría de la Comisión que califica de redundante la expresión "para la defensa de sus intereses». Dicha expresión indica claramente un fin y muestra que el Convenio protege la libertad de defensa de los intereses profesionales de los adherentes a un sindicato mediante la acción colectiva del mismo, acción cuyo desarrollo debe ser posibilitado por los Estados Contratantes. El Tribunal entiende que, por tanto, los miembros de un sindicato para la defensa de sus intereses tienen derecho a que el mismo sea oído. El artículo 11.1, deja a cada Estado la elección de los medios a emplear a este fin; la consulta es uno de ellos, pero existen otros. Lo que exige el Convenio es que la legislación nacional permita a los sindicatos luchar por la defensa de los intereses de sus miembros, de acuerdo con modos de acción que no sean contrarios al artículo 11 .

40 Nadie discute que el Sindicato demandante puede actuar de diversas formas ante el Gobierno; puede, por ejemplo, presentar reivindicaciones e intervenir para la defensa de los intereses de sus miembros o de algunos de entre ellos, y no sugiere que sus iniciativas sean ignoradas por el Estado. En dicho contexto, el hecho de que el Ministro del Interior no lo consulte de acuerdo con la Ley de 27 de julio de 1961 no viola el artículo 11.1 considerado aisladamente. 


\section{Derecho interno}

\subsection{Constitución}

Los arts. 9.2 y 129.3 CE, que establecen que los poderes públicos promoverán eficazmente las diversas formas de participación en la empresa y fomentarán, mediante una legislación adecuada, las sociedades cooperativas, como medio de facilitar la participación del ciudadano en su condición de trabajador en la vida económica, en el marco de la empresa. No son derechos fundamentales tutelables en amparo (vid. STC 120/90).

El art. 28.1 CE: cuando los despliega o se refiere a un sindicato o una de sus secciones sindicales los derechos de información y consulta se integran en el derecho a la actividad sindical, como parte del contenido esencial del derecho de libertad sindical (art. 28.1 CE).

Al respecto, el Tribunal Constitucional en su sentencia 213/2002, de 11 de noviembre (RTC 2002, 213), y con referencia al artículo 28.1 de nuestra Constitución, razonaba, que: «es preciso recordar que aunque de su tenor literal pudiera deducirse la restricción del contenido de la libertad sindical a una vertiente exclusivamente organizativa o asociativa, este Tribunal ha declarado reiteradamente, en virtud de una interpretación sistemática de los arts. 7 y $28 \mathrm{CE}$ efectuada según el canon hermenéutico del art. 10.2 CE, que llama a los textos internacionales ratificados por España —Convenios de la Organización Internacional del Trabajo núms. 87 y 98-, que su enumeración de derechos no constituye un «numerus clausus», sino que en el contenido de este precepto se integra también la vertiente funcional del derecho, es decir, el derecho de los sindicatos a ejercer aquellas actividades dirigidas a la defensa, protección y promoción de los intereses de los trabajadores, en suma, a desplegar los medios de acción necesarios para que puedan cumplir las funciones que constitucionalmente les corresponden (por todas, SSTC 105/1992, de 1 de julio (RTC 1992, 105), FF. 2 y 5; 173/1992, de 29 de octubre (RTC 1992, 173), F. 3; 164/1993, de 18 de mayo (RTC 1993, 164), F. 3 ; 145/1999, de 22 de julio (RTC 1999, 145), F. 3, y 308/2000, de 18 de diciembre (RTC 2000, 308), F. 6). Los sindicatos disponen de un ámbito esencial de libertad para organizarse y actuar de la forma que consideren más adecuada a la efectividad de su acción, dentro, claro está, del respeto a la Constitución y a la Ley.

En el art. 28.1 CE se integra, pues, el derecho a llevar a cabo una libre acción sindical, comprensiva de todos los medios lícitos y sin indebidas injerencias de terceros (por todas, SSTC 94/1995, de 16 de junio (RTC 1995, 94), F. 2; 127/1995, de 25 de julio (RTC 1995, 127) F. 3; 168/1996 de 29 octubre (RTC 1996, 168), F. 1; 168/1996, de 29 de octubre, F. 3; 107/2000, de 5 de mayo (RTC 2000, 107), F. 6, y 121/2001, de 4 de junio (RTC 2001, 121), F. 2), y, en coherencia con dicho contenido constitucional, la Ley Orgánica 11/1985, de 2 agosto (RCL 1985, 1980), de libertad sindical (en adelante, LOLS), reconoce en su art. $2.1 \mathrm{~d}$ ) «el derecho a la actividad sindical», regulando su ejercicio dentro de la empresa en sus arts. 8 a 11 . Sin necesidad de su exposición exhaustiva, es de seńalar que para el cabal ejercicio de la acción sindical, la Ley Orgánica de libertad sindical otorga a los delegados sin- 
dicales iguales derechos y garantías que el estatuto de los trabajadores destina a los miembros de comités de empresa y a éstos como instituciones de representación electiva de los trabajadores. De este modo, a través de la explícita remisión a lo dispuesto en el art. 64 LET (RCL 1995, 997), se reconoce a los delegados sindicales el derecho a acceder a la misma documentación e información que la empresa ha de poner a disposición del comité de empresa, por lo que les compete conocer, entre otros extremos, de "las estadísticas sobre el índice de absentismo y sus causas, los accidentes de trabajo y enfermedades profesionales y sus consecuencias, los índices de siniestralidad, los estudios periódicos o especiales del medio ambiente laboral y los mecanismos de prevención que se utilicen» (art. 10.3.1 LOLS, en relación con el art. 64.1.8 LET).

(Vid STC 213/2002 de 11 de noviembre; STS 8 julio 2014. RJ 2014\4521, STS 19 febrero 2009, RJ 2009/1620).

\subsection{Leyes}

— Arts. 61, 64, 65 y 68 ET: establecen los derechos de participación, información, consulta y audiencia en general, así como sus límites las garantías de los representantes unitarios, dando cumplimiento a los compromisos internacionales y comunitarios (Convenio 135 OIT y Directiva 2002/14). El contenido de estos preceptos será ampliamente comentado a lo largo de este estudio.

- Art. 10.1.3 LOLS: en cumplimiento del art. 5 del Convenio 135OIT, dispone que los delegados sindicales, en el supuesto de que no formen parte del comité de empresa, tendrán las mismas garantías que las establecidas legalmente para los miembros de los comités de empresa o de los órganos de representación que se establezcan en las Administraciones Públicas, así como los siguientes derechos a salvo de lo que se pudiera establecer por convenio colectivo:

Tener acceso a la misma información y documentación que la empresa ponga a disposición del comité de empresa, estando obligados los delegados sindicales a guardar sigilo profesional en aquellas materias en las que legalmente proceda.

Asistir a las reuniones de los comités de empresa y de los órganos internos de la empresa en materia de seguridad e higiene o de los órganos de representación que se establezcan en las Administraciones Públicas, con voz pero sin voto.

Ser oídos por la empresa previamente a la adopción de medidas de carácter colectivo que afecten a los trabajadores en general y a los afiliados a su sindicato en particular, y especialmente en los despidos y sanciones de estos últimos.

- LO 3/07 de 22 de marzo para la Igualdad efectiva de mujeres y hombres: en sus arts. 45,47.4,62,64 y 73 contempla la participación, información y consulta de los trabajadores en materia de Igualdad, en ámbitos como 
los planes de igualdad, protocolos de actuación frente al acoso sexual y al acoso por razón de sexo, Plan de Igualdad en la Administración General del Estado y en los organismos públicos vinculados o dependientes de ella y acciones de responsabilidad social de las empresas en materia de igualdad.

-Arts. 33-40 LPRL, que contemplan los derechos de participación de los trabajadores en materia de prevención de riesgos laborales a través de los delegados de prevención, el Comité de Seguridad y Salud y la colaboración con la ITSS

—RDL 5/00 de 4 de agosto (TRLISOS): art. 7.7 que, castiga como infracción grave la transgresión de los derechos de información, audiencia y consulta delos representantes del os trabajadores y del os delegados sindicales, en los términos en que legal o reglamentariamente estuvieren establecidos.

— Ley 10/97 de 24 de abril, sobre derechos de información y consulta en empresas de dimensión comunitaria.

— Ley 36/11 de 10 de octubre reguladora de la jurisdicción social (LRJS). En su art. 153.3 se contempla el proceso de impugnación de decisiones de la empresa de atribuir carácter reservado o de no comunicar determinadas informaciones a los representantes de los trabajadores, así como los litigios relativos al cumplimiento por los representantes de los trabajadores y los expertos que les asistan de su obligación de sigilo.

\subsubsection{El art. $64 E T$}

De entre todas estas normas, brilla con luz propia el art. $64 \mathrm{ET}$, por lo que consideramos oportuno, aunque brevemente, hacer algunas consideraciones sobre el mismo.

Se trata del precepto que contempla, fuera de los supuestos de reorganización productiva, sea mediante flexibilidad interna (arts. 40,41,82.3) como externa (art. $51 \mathrm{ET}$ ), los flujos de información y documentación que de forma periódica la empresa debe transmitir a los representantes de los trabajadores y a los delegados sindicales que no formen parte del Comité de Empresa (art. 10.3.1 LOLS).

De todo ese caudal de información conviene destacar, a los efectos de la negociación colectiva, la información sobre situación de la empresa y evolución del empleo.

El fundamento de esta información lo hallamos en la Directiva 2002/14/CE de 11 de marzo de 2002, que ha sido traspuesta por la Ley 38/07, que da nueva redacción al art. $64 \mathrm{ET}$, incorporando las exigencias de la Directiva marco (art. 4). 
En este sentido se identifican los fines de la información y consulta con los representantes los trabajadores en estas materias con los de «favorecer la prevención de los riesgos, flexibilizar la organización del trabajo y facilitar el acceso de los trabajadores a la formación dentro de la empresa en un marco de seguridad, concienciar a los trabajadores acerca de las necesidades de adaptación, aumentar la disponibilidad de los trabajadores para adoptar medidas y emprender acciones destinadas a reforzar sus posibilidades de empleo, promover la participación de los trabajadores en la marcha y el futuro de la empresa y fortalecer la competitividad de ésta ${ }^{29}$ ».

Hay que precisar que se trata del deber de informar, no del deber de consensuar las cuestiones atinentes a la política empresarial, actividades, producción o venta, pues ello entra dentro del ámbito de la libertad de empresa del art. 38 $\mathrm{CE}$, que implica como parte de su contenido esencial el derecho a decidir y diseñar los objetivos de la empresa y planificar su actividad ${ }^{30}$.

Sentadas tales premisas pasamos a examinar los derechos en concreto.

Así, el art. 64. 2. ET dispone que el comité de empresa tendrá derecho a ser informado trimestralmente:

a) Sobre la evolución general del sector económico a que pertenece la empresa.

b) Sobre la situación económica de la empresa y la evolución reciente y probable de sus actividades, incluidas las actuaciones medioambientales que tengan repercusión directa en el empleo, así como sobre la producción y ventas, incluido el programa de producción.

$\mathrm{El}$ art. 64.4 ET dispone que el comité de empresa, con la periodicidad que proceda en cada caso, tendrá derecho a:

29 Vid. punto 7 de la exposición de motivos de la Directiva 2002\14.

30 Según el TC (STC 71/08 de 26 de febrero): el art. 38 CE, directamente conectado con los arts. 128 y 131 CE (SSTC 37/1981, de 16 de noviembre [RTC 1981, 37], F. 2; 111/1983, de 2 de diciembre [RTC 1983, 111], F. 10; 225/1993, de 8 de julio [RTC 1993, 225], F. 3 b), y 96/2002, de 25 de abril [RTC 2002, 96], F. 11), al garantizar la «libertad de empresa en el marco de la economía de mercado", no reconoce "el derecho a acometer cualquier empresa, sino sólo el de iniciar y sostener en libertad la actividad empresarial, cuyo ejercicio está disciplinado por normas de muy distinto orden" (STC 83/1984 [RTC 1984, 83], F. 3; reiteran esta doctrina las SSTC 84/1993, de 8 de marzo [RTC 1993, 84], F. 2 b); 225/1993, de 8 de julio [RTC 1993, 225], F. 3 b); 96/2002, de 25 de abril [RTC 2002, 96], F. 11; y 112/2006, de 5 de abril [RTC 2006, 112], F. 8), lo que entraña «en el marco de una economía de mercado, donde este derecho opera como garantía institucional, el reconocimiento a los particulares de una libertad de decisión no sólo para crear empresas y, por tanto, para actuar en el mercado, sino también para establecer los propios objetivos de la empresa y dirigir y planificar su actividad en atención a sus recursos y a las condiciones del propio mercado» (SSTC 225/1993, de 8 de julio, F. 3 b), y 112/2006, de 5 de abril, F. 8). 
a) Conocer el balance, la cuenta de resultados, la memoria y, en el caso de que la empresa, prevista la forma de sociedad por acciones o participaciones, los demás documentos que se den a conocer a los socios, y en las mismas condiciones que a éstos.

En este sentido, téngase en cuenta que las SA y las SL deben entregar dentro de los 6 primeros meses siguientes a la finalización de cada ejercicio la misma información que a los socios: cuentas anuales, balances, informe de gestión, propuesta de aplicación de los resultados. (vid art. 93 d), arts. 196 y 197 RDL 1/2010).

En cuanto al contenido de las cuentas anuales y, por tanto, la información que las mismas transmiten, hay que estar a lo que disponen los arts 253-284, contenidos en el Título VII del RDL 1/10.

El art. 64. 5. ET establece que el comité de empresa tendrá derecho a ser informado y consultado sobre la situación y estructura del empleo en la empresa o en el centro de trabajo, así como a ser informado trimestralmente sobre la evolución probable del mismo, incluyendo la consulta cuando se prevean cambios al respecto.

Asimismo, tendrá derecho a ser informado y consultado sobre todas las decisiones de la empresa que pudieran provocar cambios relevantes en cuanto a la organización del trabajo y a los contratos de trabajo en la empresa.

En cuanto a la forma de facilitar la información, las SSTCT 11 enero 1980 y 26 abril de 1989 y la más reciente STSJ Canarias, Las Palmas núm. 1026/2001 de 19 diciembre (Recurso 1572/1999), distinguen:

1) información relativa a la evolución del sector económico al que pertenezca la empresa situación productiva y de ventas de ésta programas al respecto y previsibilidad de empleo en la misma: debe facilitarse por escrito.

2) balance cuenta de resultados y memoria: cierta interpretación literalista ha considerado que no debe facilitarse necesariamente por escrito.

En este sentido se pronuncia la STSJ de Murcia, (Sala de lo Social) Sentencia de 5 octubre 1992 (Recurso 384/92), en que se deniega el derecho solicitado por el sindicato a la entrega de la documentación solicitada (balance, cuentas de resultados y memoria) y el acceso del asesor del sindicato, pues si el art. 64 del Estatuto de los Trabajadores habla sólo de "conocer», y, en la demanda se pide la "entrega», la pretensión debe ser rechazada.

En cuanto a la información sobre evolución del empleo, venta y línea de producción, se ha declarado por la STSJ País Vasco, núm. 1510/2004 de 13 julio (Recurso 892/2004) que si la empresa «la ha facilitado a través de anun- 
cios cargados en el tablón de anuncios existente en el centro de trabajo y por medio de una reunión en los que se les expusieron unas filminas", dicha forma de transmisión es insuficiente, pues no se comprende por qué una información que se debe dar al comité se le entrega a través del tablón de anuncios, y por qué la documentación que se le da no es en soporte papel, sino en filminas que se proyectan en breve espacio de tiempo, impidiendo la necesaria reflexión y conclusiones que requiere una información de esta complejidad.

En los supuestos de cuadrantes horarios de los trabajadores, la doctrina contenciosa (STSJ Madrid (Sala de lo Contencioso) núm. 401/2006 de 20 abril [Recurso 147/2004]) se ha pronunciado en el sentido de que si bien parece evidente que para que el Comité pueda ejercer esa labor de vigilancia tiene el derecho a conocer los cuadrantes horarios de los servicios de los trabajadores ya que se relacionan con cuestiones tales como el cumplimiento del horario máximo y la realización de horas extraordinarias, no existe norma alguna que establezca la forma en que ha de tomar dicho conocimiento... ni que establezca que ello debe de ser mediante la entrega por parte de la empresa de la documentación relativa a los cuadrantes horarios ó copia de ella para su examen fuera de los locales de la empresa, como pretende el inspector.

En lo atinente a la prescripción del derecho a solicitar la información, se aplica el plazo de 1 ańo del art. 59 (vid. STSJ de Andalucía, Málaga núm. 980/1999 de 30 abril [Recurso 2263/1998]), pues esta obligación de información de la empresa no puede ser ilimitada en el tiempo, sino que, teniendo que proporcionarla con carácter trimestral, desde el transcurso del trimestre el Comité dispone del plazo de un año para exigir judicialmente el cumplimiento efectivo de dicha obligación empresarial.

En cuanto a la periodicidad de la información, es mejorable por pacto, pero si no es así, la STSJ Madrid, de 27 abril 1993 (Recurso 2111/1993), establece que el Comité debe ser informado, no con periodicidad mensual, sino trimestral del número de kilos vendidos, ya que en función del resultado de las ventas perciben determinadas primas los trabajadores, por lo que el motivo debe acogerse en parte, en cuanto el derecho a información sobre este extremo se corresponde a un período trimestral, conforme al art. 64.1.1 del ET.

\subsection{Autonomía colectiva}

El art. 64. 9 ET dispone que respetando lo establecido legal o reglamentariamente, en los convenios colectivos se podrán establecer disposiciones específicas relativas al contenido y a las modalidades de ejercicio de los derechos de información y consulta previstos en este artículo, así como al nivel de representación más adecuado para ejercerlos. 
El Convenio Colectivo podrá mejorar los derechos de información contenidos en el art. $64 \mathrm{ET}$, pero en ningún caso empeorarlos, pues son mínimos de derecho necesario relativo.

Partiendo de ahí, ya es tradicional que los Acuerdos para el empleo y la negociación colectiva, adoptados en el marco del art. 83.2 ET, dediquen un pequeño apartado a los derechos de información, consulta y participación, la negociación colectiva y la interlocución sindical ${ }^{31}$.

En este sentido, el II AENC (2012-2014), sigue la misma línea trazada por el anterior AENC 2010-2012, consistente en formular una serie de consideraciones vagas y generales, sin imponer ninguna obligación y que, sin temor a equivocarnos, podríamos calificar de absolutamente intrascendente para la negociación colectiva. En efecto, lo único que hace es decir que en materia de información y consulta se debe reforzar el diálogo social sectorial, que las TIC deberían tratarse en los CCol, que hay que tener en cuenta las modificaciones introducidas en el ET y que, en fin, tal rosario de vaguedades termina — en la misma línea- con la indicación de que en el caso de las SAE o las Cooperativas europeas, resulta de aplicación la Ley 31/06.

Afortunadamente, el III AENC 2015-2017 (BOE 20 junio 2015) 32, presenta mayor precisión y más contenido sobre derechos de información y consulta. Para empezar, distingue en tres ámbitos: empresa, empresas red y empresas de dimensión comunitaria. Sigue faltando el sector como ámbito de información para la negociación colectiva.

Las obligaciones que se fijan, no obstante, no van más allá de desarrollar - fijando procedimientos-, los derechos reconocidos por la legislación en materia de información y consulta. Es decir, se pretende una cierta protocolización, pero en ningún caso la ampliación de su contenido o la flexibilización de su interpretación.

En esta línea «soft», el III AENC desgrana dicha obligación en 3 niveles, entre los que destaca, por novedoso, el relativo a las empresas en Red, nuevo ámbito de negociación introducido por el art. $87 \mathrm{ET}$, siendo de lamentar que, sin embargo, nada se diga sobre la información en la negociación en el ámbito de Grupos de empresa.

31 AENC 2010-2012 Resolución de 11 de febrero 2010. RCL 20101395.

AENC 2012-2014 Resolución de 30 de enero 2012. RCL 2012\125.

AENC 2015-2017 Resolución de 15 de junio 2015. RCL $2015 \backslash 938$.

32 III Acuerdo para el Empleo y la Negociación Colectiva 2015, 2016 y 2017, (Código de convenio n.o 99100015092012), que fue suscrito con fecha 8 de junio de 2015, de una parte, por la Confederación Española de Organizaciones Empresariales (CEOE) y la Confederación Española de la Pequeña y Mediana Empresa (CEPYME) y de otra por las Confederaciones Sindicales de Comisiones Obreras (CC.OO) y de la Unión General de Trabajadores (UGT). 
Con todo, a poco que se examine el contenido de ese desarrollo procedimental que el IIIAENC establece, se constata que no es sino una referencia a los mínimos legales y, por tanto, completamente inútil.

— En cada empresa:

- Información sobre la situación económica de la empresa y la evolución de sus actividades; las previsiones sobre el volumen y tipo de contratos; las estadísticas sobre el índice de absentismo y sus causas; la aplicación del derecho de igualdad de trato y oportunidades; y demás cuestiones en los términos previstos en el artículo 64 del ET.

- Abordar en los convenios colectivos la incidencia de las tecnologías de la información y la comunicación en las relaciones laborales, estableciendo canales de comunicación entre las partes y como vehículo de información a los trabajadores por parte de la RLT, que deberán ser objeto de un uso racional.

- La información a los representantes de los trabajadores sobre actuaciones medioambientales que tengan directa repercusión en el empleo, en las condiciones de trabajo o en el entorno territorial.

- La capacidad de representación y ámbito de actuación de los representantes de los trabajadores, así como su crédito horario, vendrán determinados por lo establecido en los convenios colectivos de aplicación conforme a la legislación vigente.

- En empresas en red:

- Información por parte de la empresa principal y contratista a sus trabajadores y a la representación legal de los mismos sobre los procesos de subcontratación, según lo establecido en el artículo 42 del ET, lo que contribuirá a la seguridad del empleo y al cumplimiento de las condiciones laborales establecidas legal y convencionalmente.

- Información por parte de la empresa usuaria a los representantes de los trabajadores sobre los contratos de puesta a disposición con las ETT, entregándoles una copia básica del contrato de trabajo o de la orden de servicio.

- Información a los trabajadores sobre los medios de coordinación fijados para proteger y prevenir los riesgos laborales en el centro de trabajo, en los términos previstos en el artículo 24 de la Ley de Prevención de Riesgos Laborales.

- Cuando las empresas, principal, contratista y subcontratista, compartan de forma continuada un mismo centro de trabajo, la primera deberá disponer de un libro de registro en el que se refleje la infor- 
mación mencionada en el artículo 42.4 del Estatuto de los Trabajadores respecto de todas las empresas citadas. Dicho libro estará a disposición de los representantes legales de los trabajadores.

- Los trabajadores de las empresas contratistas y subcontratistas cuando no tengan representación legal tendrán derecho a formular a los representantes de los trabajadores de la empresa principal cuestiones relativas a las condiciones de ejecución de la actividad laboral, mientras compartan centro de trabajo y carezcan de representación. Lo dispuesto en el párrafo anterior no será de aplicación a las reclamaciones del trabajador respecto de la empresa de la que depende.

- Los representantes legales de los trabajadores de la empresa principal y de las empresas contratistas y subcontratistas, cuando compartan de forma continuada centro de trabajo, podrán reunirse a efectos de coordinación entre ellos y en relación con las condiciones de ejecución de la actividad laboral en los términos previstos en el artículo 81 del Estatuto de los Trabajadores, y con los medios que se determinen mediante negociación colectiva sectorial o de empresa.

—En empresas de dimensión comunitaria:

- Información económica y laboral en las Sociedades Anónimas Europeas o Cooperativas Europeas, conforme a los mecanismos de información, consulta y participación previstos por la Ley 31/2006, de 18 de octubre, sobre implicación de los trabajadores en las sociedades anónimas y cooperativas europeas.

\section{Marco doctrinal interno}

\subsection{El convenio como instrumento de mejora de los derechos de información y consulta}

El TS ha venido considerando el CCol como un instrumento de mejora de los derechos de información y consulta en su configuración legal, en coherencia con lo que dispone el art. 64.9 ET.

Así, por ejemplo en la STS núm. 297/2016 de 19 abril (RJ 2016\1975), se defiende que el papel del Convenio en los derechos de información y consulta es siembre de suplemento de los mínimos legales, nunca de detrimento. Por esa razón, sobre la obligación de consulta e informe previo en materia de formación (art. 64.5e) ET) y sobre mejora convencional en materia de formación preventiva, el TS considera que la segunda no puede excluir la primera, dado que a la regulación legal es de mínimo de derecho necesario relativo. 
En alguna sentencia se ha empleado un criterio un tanto restrictivo a la hora de interpretar las obligaciones convencionales. Así, por ejemplo, en la STS 18 junio 2013 (RJ 2013\5738) se interpreta que lo pactado en convenio (art. 36 del CCol de Eads Casa Airbus España y Eads Casa Espacio ${ }^{33}$ ) sobre información relativa a cambios de jornada y horarios, no es aplicable al caso al no haberse acreditado que los trabajadores hayan superado la jornada anual pactada, ni que hayan reclamado compensación alguna por haber superado la citada jornada.

El convenio, sin embargo, no condiciona el derecho a que se acredite la superación de la jornada anual, sino que más bien la información es un requisito previo para controlar que la misma no se supere.

El art. 36.2 del Convenio dice:

La dirección del centro informará previamente, a la representación de los trabajadores sobre los siguientes aspectos: Realización de trabajos de inferior grupo profesional. Planes generales de formación. Sanciones por faltas muy graves. Horas extraordinarias. Flexibilidad de tiempo de trabajo. Política de personal. Seguridad y salud Cambio de jornadas y horarios. Absentismo. Contratación de personal. Subcontratación de trabajos al exterior. Jubilaciones. Previsión de plantillas. Concesión de excedencias. Implantación de turnos. Sistema de incentivos Acoplamiento de personal disminuido. Retribución variable.

Para terminar, la naturaleza de derecho mínimo indisponible in peius de los derechos de información y consulta, aparece con claridad en la STS 11 diciembre 2003 (RJ 200412577) Los derechos de información no son exceptuables por pacto con los representantes de los trabajadores. Constituyen mínimos de derecho necesario relativo:

...la Disposición Adicional 3.a del RD 1561/95 de 21 de septiembre) sobre jornadas especiales de trabajo, señala que la representación de los trabajadores tiene derecho a «ser informados mensualmente por el empresario de las horas extraordinarias realizadas por los trabajadores, cualquiera que sea su forma de compensación, recibiendo a tal efecto copia de los resúmenes a que se refiere el apartado 5 del artículo 35 del Estatuto de los Trabajadores». La Sala no acepta la exoneración de este concreto deber de información, que según el empleador se ha producido por pacto con los trabajadores, por el simple dato de que —al margen de problemas derivados de su posible ineficacia - no consta la existencia del pacto en los hechos probados.

33 Resolución de 21 de octubre 2008, LEG 200817122. 


\subsection{Negociación colectiva y derechos de información y consulta}

Sobre el derecho de información en los supuestos de negociación colectiva de convenios estatutarios vale la pena detenerse en la STS 11 diciembre 2015 (recurso: 15/2015), en que se plantea el interesante tema de los derechos de información y consulta, esta vez en el marco de la negociación colectiva de un convenio de empresa.

El Sindicato CCOO formula una acción de conflicto colectivo en el marco de una negociación de convenio colectivo de empresa (RTVE), con una triple pretensión:

a) declarar que durante el proceso negociador se lesionó el derecho de información y libertad sindical de CCOO, porque la empresa «no entregó la información económica correcta»;

b) declarar que la empresa «no ha negociado bajo el principio de buena fe»; y

c) declarar el derecho de la representación legal de los trabajadores «a recibir la misma información económica y, por lo tanto, una información completamente coincidente con la que dispone el Consejo de Administración de la entidad demandada».

La AN despachó las dos primeras pretensiones por «falta de acción». Mantiene la AN que concurre falta de acción por inexistencia de «interés litigioso real $y$ actuali, razonando al efecto que

de ser cierto que la empresa no proporcionó la información correcta a los demandantes durante la negociación del convenio, lo que se asocia a una vulneración del deber de negociar de buena fe, exigido por el art. 89.3 ET, la acción consecuente sería la impugnación del convenio colectivo por ilegalidad, o, en su defecto, una reclamación de daños y perjuicios..., pero no cabe, de ningún modo, reclamar que se reprochen genéricamente dichas actuaciones por los órganos jurisdiccionales, por cuanto los tribunales no están para realizar declaraciones genéricas sin más relevancia jurídica que la meramente propagandística, cuando se han podido reclamar pretensiones concretas y actuales, como anticipamos más arriba.

La AN desestima la tercera pretensión (recibir la misma información económica y, por lo tanto, una información completamente coincidente con la que dispone el Consejo de Administración) porque

el derecho de información de los representantes de los trabajadores... comporta que la empresa esté obligada a aportar la documentación prevista legal o convencionalmente, así como la pactada durante todo el proceso negociador, pero no permite concluir que los representantes de los trabajadores puedan reclamar ilimitadamente información, que vaya más allá de las exigencias previstas legal o convencionalmente, así como las que se acuerden durante el desarrollo de la negociación... exigir la aportación a los representantes de los trabajadores durante la negociación colectiva como 
documentación pertinente para que la negociación colectiva alcance sus fines idéntica información que la manejada por el Consejo de Administración de CRTVE para el cumplimiento de sus funciones constituye una pretensión absolutamente desproporcionada y supondría proporcionar a los representantes de los trabajadores informaciones, que exceden con mucho, sus necesidades informativas para el cumplimiento de sus funciones.

El TS aprecia que respecto de la tercera pretensión el sindicato plantea cuestiones nuevas en el recurso y no entra a resolver el mismo. Sin embargo, sí entra a resolver, confirmándola, la existencia de falta de acción para las pretensiones de declarar que durante el proceso negociador se lesionó el derecho de información y libertad sindical y declarar que la empresa «no ha negociado bajo el principio de buena fe.

El TS confirma la falta de acción por las siguientes razones:

...la ausencia de «interés real y actual» en la sentencia declarativa que se pretende, puesto que el legítimo ejercicio de la acción declarativa presupone la existencia de un derecho insatisfecho al que se trata de tutelar mediante la acción, y es precisamente este último - la tutela que se pretende- y la necesidad de protección jurídica - base de la acción - lo que no ha apreciado la Audiencia Nacional y que tampoco acierta a ver esta Sala, que no encuentra en la pretensión ejercitada más que una cierta "satisfacción» o "proyección de imagen» de que nos habla la decisión recurrida, intereses ciertamente legítimos pero que no pueden servir de base al pronunciamiento judicial que se pide, nunca obtenible cuando falta una cuestión actual o efectiva y la ya referida necesidad de protección jurídica (entre muchas otras, SSTS 16/09/09 [RJ 2009, 6156] —rcud 2570/08—; 26/04/10 [RJ 2010, 4865] —rcud 2290/09—; 14/04/10 [RJ 2010, 4654] —rcud 2490/09-; y 23/06/14 —rco 227/13 [RJ 2014, 4760]-). Razones - las precedentes- del todo compatibles con la circunstancia de que el art. 24.1 CE (RCL 1978, 2836) imponga que cualquier interés legítimo y precisado de tutela judicial efectiva deba obtenerla (SSTC 71/1991, de 8/Abril [RTC 1991, 71] ; 210/1992, de 30 noviembre [RTC 1992, 210] ; y 65/1995, de 8/Mayo [RTC 1995, 65]) (SSTS -reiterando criterio anterior- 20/01/15 [RJ 2015, 359] —rcud 2230/13 —; 15/09/15 [RJ 2015, 4544] —rco 252/14—; y 23/06/15 [RJ 2015, 5533] —rcud 944/14-), pues tal como argumenta con acierto la decisión recurrida, la posible conculcación de los derechos fundamentales que el Sindicato accionante invoca, bien pudiera haber dado lugar a concretas peticiones en orden a la eficacia jurídica del Convenio Colectivo suscrito o a los dańos y perjuicios producidos a la parte accionante con aquellas vulneraciones, pero no a la mera declaración judicial de que estas últimas han existido.

Como comentario sobre esta resolución:

- en cuanto a la falta de acción: parece que se anuda de forma ineludible la acción declarativa de la falta de información en la negociación y consiguiente vulneración de la libertad sindical, a la necesidad de de- 
nunciar la ilegalidad del convenio, cuestión que sería debatible, si tenemos en cuenta que la lesión de la libertad sindical se produce en el mismo momento en que no se transmite toda la información o se transmite erróneamente, y la indemnización por daños y perjuicios derivada de la misma entra dentro del principio dispositivo. En cuanto a la «acción propagandística» de que habla la sentencia, quizás convendría recordar que el descrédito del sindicato por la falta de información y por lo que ello comporta en la negociación es un parámetro a valorar en sede de daños morales (STS 7 marzo 2011 [FJ 4. $\left.{ }^{\circ}\right]$ (RJ 2011\3111).

Por tanto, bien podía sostenerse que sí existía acción para declarar la vulneración de un derecho fundamental a la libertad sindical por falta de información, sin perjuicio del ulterior resultado de la negociación.

Creo que es importante distinguir ambos ámbitos puesto que el derecho de información, aunque instrumental, tiene sustantividad propia y su infracción vulnera la libertad sindical.

En cuanto a la pretensión de que se aportara la misma documentación que al Consejo de Administración, hay que precisar que el art. 64.4 a) ET da derecho a los RLT o a las Secciones sindicales a "Conocer el balance, la cuenta de resultados, la memoria y, en el caso de que la empresa, prevista la forma de sociedad por acciones o participaciones, los demás documentos que se den a conocer a los socios, y en las mismas condiciones que a éstos».

El art. 93 d) LSC (RDL 1/10), establece que los socios tienen derecho a la información. Dicho derecho se desarrolla en los arts. 196 y 197 de la LSC donde se limita la información al contenido del orden del día o a las preguntas pertinentes. En estos casos, los administradores estarán obligados a proporcionar la información solicitada al amparo de los dos apartados anteriores, salvo que esa información sea innecesaria para la tutela de los derechos del socio, o existan razones objetivas para considerar que podría utilizarse para fines extrasociales o su publicidad perjudique a la sociedad o a las sociedades vinculadas.

Distinto del derecho de información del socio es el derecho de información del órgano de administración, que se contempla en el art. 225 LSC, que establece que "En el desempeño de sus funciones, el administrador tiene el deber de exigir y el derecho de recabar de la sociedad la información adecuada y necesaria que le sirva para el cumplimiento de sus obligaciones"; por otro lado, el art. 228b) LSC obliga al Administrador a "Guardar secreto sobre las informaciones, datos, informes o antecedentes a los que haya tenido acceso en el desempeño de su cargo, incluso cuando haya cesado en él, salvo en los casos en que la ley lo permita o requiera». 
Partiendo de ello, la información que recibe el administrador no tiene el mismo régimen que la que recibe el socio y, los RLT y las Secciones Sindicales tienen derecho a recibir la que recibe el socio, por lo que —en abstracto- sería desproporcionada una petición genérica de recibir la misma información que el consejo de administración. No sería desproporcionado, sino lo legalmente establecido, pedir la misma información que los socios.

No obstante, hechas estas consideraciones generales, hay que precisar que en el caso de autos (f $2 .^{\circ}$ ), la cuestión fáctica que se debate es que la información que pedía el sindicato era la que le correspondía a los socios, pero que, sin embargo, había sido entregada al consejo de administración en lugar de la mesa negociadora.

\subsection{Cuestiones relativas al contenido del derecho}

El contenido del derecho de información, como hemos apuntado con anterioridad, es ampliable por vía de convenio colectivo, sin embargo en la interpretación del convenio, igual que en el de la ley, se ha seguido un criterio estricto, literalista, para nada enfocado a la finalidad propia de la información, que no es otro que el ejercicio de la libertad sindical en la empresa. Así por ejemplo, aunque referida a los RLT, tenemos la STS 13 octubre 2011 (RJ 2011\7718), en que se discute la interpretación de derechos informativos sobre gratificaciones y se resuelve que el alcance del derecho de información sobre las gratificaciones reguladas en el art. 163 del Reglamento de Trabajo del Banco de España. Derecho del sindicato demandante a recibir información documentada sobre la cuantía global de las gratificaciones, el número de empleados que la han recibido, los porcentajes por grupos y niveles y por hombres y mujeres desde los dos últimos años, sin que pueda extender a otros extremos, tales como los parámetros observados, para los que la negociación colectiva ha dotado de libertad en su organización a la empresa.

El control de horas extraordinarias (art. 35.5 ET y DA 3 b) RD 1561/95 de 21 de septiembre) ha sido una cuestión litigiosa, como se plasma, por ejemplo en la STS 3 octubre 2006 (RJ 2006/8018), en esta sentencia se confirma la de la AN en que se declara el derecho de los trabajadores de la demandada Caja de Ahorros y Pensiones de Barcelona a que no se destruyan los datos que recoge el sistema de marcaje horario en el período de un ańo - inciso segundo de la pretensión a) de la demanda; y ello en función de un Pacto de 25 de octubre de 1991 sobre "control horario y horas extraordinarias»,; sin embargo desestima otras pretensiones por no estar previstas en el citado Pacto, como la de que se entregue diariamente a los trabajadores el justificante de la hora de entrada y de salida.

Sobre el mismo pacto en el Sector de Cajas de Ahorros relativo a las horas extraordinarias, se pronuncia la STS 25 abril 2006 (RJ 2006\2397), que revoca 
la de la sentencia de la AN, en la que estima que la obligación de información que cabe imponer a la empresa ha de pasar por la consideración previa de la naturaleza de las eventuales horas de exceso realizadas, de manera que si el Convenio Colectivo de las Cajas de Ahorros (BOE de 15 de marzo de 2004) establece una jornada anual de 1.680 horas de trabajo efectivo (artículo 31.1) sólo podrá saberse si se han realizado horas extraordinarias al final del año. Por eso la empresa sostiene, y la sentencia recurrida asume como base de la desestimación de la demanda, que al no haberse acreditado que se haya rebasado en ningún caso esa jornada anual, no han existido horas extraordinarias en la empresa y por ello no existe obligación de trasladar información de clase alguna, puesto que la relativa a la no realización de tales horas extras o de horas extras «00» no resulta en ningún caso exigible.

Sin embargo, el TS, con buen criterio, considera que de forma taxativa e incuestionable, el Pacto de 25 octubre 1991, la DA 3.ab) RD 1561/95 y el propio ET (art. 35) contienen una obligación de información sobre la realización de horas extraordinarias de forma mensual, no en cómputo anual. Pero además, esa obligación periódica se extiende también a las horas compensadas y a las pendientes de compensación. De hecho, el Pacto de 1991 tiene como anexo - el número 3- un estadillo modelo que recoge día a día las horas de exceso en la jornada del trabajador y las compensaciones habidas, para que en el correspondiente resumen mensual se consigne la jornada que se ha realizado en cada caso.

En conclusión, el TS revoca la SAN de 12/07/05, por interpretar erróneamente los preceptos objeto de comentario y considerar indebidamente que había de transcurrir 1 ańo para saber si las horas eran o no extraordinarias. El TS, de acuerdo con el Pacto de 1991, considera que la obligación de información es mensual y no anual.

\subsection{Criterio restrictivo o numerus clausus del contenido del derecho de información}

En el presente apartado veremos varios ejemplos del criterio restrictivo o de numerus clausus que ha seguido el TS — con alguna rara excepción- a la hora de interpretar el contenido del derecho de información.

Partiremos del ejemplo más reciente, la STS 9 octubre 2015. RJ $2015 \backslash 5665$, en la que se reitera la doctrina del concepto "taxativo o de numerus clausus» de la información prevista en el art. 64 ET. Acoge un concepto restrictivo, formalista y no finalista de la información (SSTS 20 de junio de 2012, Rc 176/11 [RJ 2012, 9966], STS de junio de 2010, Rc 60/08 [RJ 2010, 5933] y de 19 de febrero de 2009 (6/2008) [RJ 2009, 1620], según la cual, la jurisprudencia recaída hasta la fecha no permite llevar el alcance de las materias acogidas al derecho de información más allá de los términos empleados por 
los preceptos que lo regulan. Reputa innecesaria una información (número de clientes desglosado por comunidad autónoma y provincia), que la propia sentencia reconoce que podría ser pertinente en supuestos de flexibilidad interna o externa:

En este caso se ventila una solicitud a la empresa de información trimestral a Delegados de Personal sobre el número de clientes desglosado por comunidad autónoma y provincia: desestimación: las empresas demandadas informan trimestralmente a los representantes de los trabajadores sobre la evolución general del sector económico; evolución reciente y probable de la actividad de la empresa; situación sobre la producción, que contiene el número global de instalaciones y servicios prestados por cada compañía mes a mes; situación sobre ventas y programas de producción; previsiones de nuevos contratos; previsión de horas complementarias por empleados a tiempo parcial; previsión de supuestos de contratación; absentismo, accidentes de trabajo, enfermedades profesionales e índices de siniestralidad y estudios de medio ambiente laboral y mecanismos de prevención, de todo lo cual es fácil deducir el número global de clientes a través de la suma del número de instalaciones y servicios. Por el contrario, no ha acreditado el Sindicato recurrente que la información desglosada por comunidades autónomas y por provincias sea imprescindible, o al menos conveniente para el desarrollo de su actividad sindical en el marco de los derechos de información, a la vista de la documentación que, según el factum de la sentencia, facilita trimestralmente la empresa a los representantes de los trabajadores. Por ello, termina diciendo la sentencia: «si las empresas promueven en el futuro medidas de flexibilidad interna o externa, deberán informar necesariamente a los representantes de sus trabajadores en los términos exigidos por los arts. 40, 41, 47, 51 y $82.3 \mathrm{ET}$, en cuyo caso podría ser pertinente informar, según sean los centros afectados, sobre los clientes globales de la empresa, por comunidades autónomas o por provincias, pero no hay razón para que se anticipe la información desglosada, cuando los representantes de los trabajadores disponen puntualmente [de ella] sobre la clientela global de la empresa, así como sobre su evolución mensual, lo que les permite hacerse una composición objetiva y solvente de la situación de las compañías, que les posibilitara anticipar los movimientos de la empresa y definir, en su caso, sus propias estrategias sindicales.

No es atendible la invocación de los recurrentes de que debe prevalecer una interpretación finalista del precepto controvertido, apoyándose en las sentencias de esta Sala, de 3 de mayo (RJ 2011, 4503) y 13 de octubre de 2011 (RJ 2011, 7718) (Rec $168 / 2010$ y $210 / 2010$ ), pues se refieren a supuestos diferentes al aquí examinado: La primera se refiere a que la empresa debe facilitar la información interesada por los delegados sindicales en los mismos términos que al Comité de Empresa, en virtud de lo dispuesto en el art. 64.7 del Estatuto y Convenio Colectivo de aplicación, y la segunda, se refiere a la información sobre reconocimiento de un derecho con origen en un convenio colectivo.

En el mismo sentido, la STS 20 junio 2012 (RJ 2012\9966), en que se plasma la criticable doctrina sobre el carácter taxativo o "numerus clausus» de la información, en este caso en materia de contratas ero 2012 (RJ 201214969), 
en la que a interpretado de forma rigorista, por ejemplo en la do con el Pacto de 1991, considera que:

El derecho a recibir información en materia de subcontratación comprende la referente al número de trabajadores ocupados en la empresa en relación a las empresas contratistas y subcontratistas, así como a las asistencias técnicas y encomiendas de gestión concertadas, pero no la concerniente a la identidad de los trabajadores, puesto de trabajo que ocupan, tipo de contrato y categoría profesional.

La recurrente en un último intento de transformar el tenor literal de los textos legales aduce el contenido de artículo 64.7. .e) del Estatuto de los Trabajadores «informar a sus representados en todos los temas y cuestiones señalados en este artículo en cuanto directa o indirectamente tengan o puedan tener repercusión en las relaciones laborales» para sustituir el «numerus clausus» de los artículos 42.4 y $64.1 .^{\circ}, 2 .^{\circ}, 3 .{ }^{\circ}, 7 .{ }^{\circ}$ y $8 .^{\circ}$ por el «numerus apertus» del artículo 64.7..$e$ ), que lejos de referirse al derecho de información de los representantes de los trabajadores frente a la empresa se refiere a la obligación de información de los representantes respecto de los trabajadores, a lo que se añade quienes habrán de ser los sujetos receptores de dicha información, en su caso trabajadores información, que a su vez cuentan con otros comités de empresa encargados de la representación de sus intereses.

Como acertadamente indica el Ministerio Fiscal en su informe, con cita de las Sentencias del Tribunal Supremo de 19 de febrero de 2009 (RJ 2009, 1620) (Rec. 6/2008) y de primero de junio de 2010 (Rec. 60/2008) (RJ 2010, 5933), la jurisprudencia recaída hasta la fecha no permite llevar el alcance de las materias acogidas al derecho de información mas allá de los términos empleados por los preceptos en los que el mismo se regula. En todo caso el relato histórico no suministra datos que permitan otorgar al comité actor un control sobre las actividades de las empresas dependientes a través de contratos, subcontratos, asistencias técnicas y encomiendas que pudiera corresponder a los respectivos comités de empresa.

Como crítica a esta resolución podemos apuntar que el números apertus no viene del art. 64.7 e) sino del art. 64.6 ET: en un momento, de una manera y con un contenido "adecuados». La cuestión es, pues, si es compatible el momento, manera y contenido adecuados a que se refiere la Directiva 2002/14 con la doctrina del numerus clausus.

La doctrina del numerus clausus se ha interpretado de forma rigorista, por ejemplo en la STS 17 enero 2012 (RJ 2012\4969), en la que no se aprecia vulneración de los derechos informativos de la sección sindical, al no alcanzar dicho derecho la entrega de una copia del contrato de fusión empresarial, lo cuál resulta dudoso si tenemos en cuenta que la empresa ha de facilitar a los RLT la misma información que haya de facilitar a los socios (art. 64.a), que en los casos de fusión de sociedades viene contemplada en el 
art. 39 de la Ley 3/09 de 3 de abril sobre modificaciones estructurales de las sociedades mercantiles ${ }^{34}$.

En el caso de los representantes de los trabajadores la tutela de los derechos de información disminuye por que salen de la órbita de la libertad sindical, y su interpretación estricta se incrementa, como se puede ver en la STS 2 noviembre 1999. RJ 199919108, doctrina que parte de un momento anterior a la Directiva 2002/14 y que se ha mantenido invariable de forma acrítica.

\section{En efecto, en la citada resolución se asevera:}

34 1. Antes de la publicación del anuncio de convocatoria de las juntas de socios que hayan de resolver sobre la fusión o de la comunicación individual de ese anuncio a los socios, los administradores deberán insertar en la página web de la sociedad, con posibilidad de descargarlos e imprimirlos o, si no tuviera página web, poner a disposición de los socios, obligacionistas, titulares de derechos especiales y de los representantes de los trabajadores, en el domicilio social, los siguientes documentos:

$1 .^{\circ}$ El proyecto común de fusión.

2..$^{\circ}$ En su caso, los informes de los administradores de cada una de las sociedades sobre el proyecto de fusión.

3. ${ }^{\circ}$ En su caso, los informes de los expertos independientes.

4. ${ }^{\circ}$ Las cuentas anuales y los informes de gestión de los tres últimos ejercicios, así como los correspondientes informes de los auditores de cuentas de las sociedades en las que fueran legalmente exigibles.

5. ${ }^{\circ}$ El balance de fusión de cada una de las sociedades, cuando sea distinto del último balance anual aprobado, acompañado, si fuera exigible, del informe de auditoría o, en el caso de fusión de sociedades cotizadas, el informe financiero semestral por el que el balance se hubiera sustituido.

6. ${ }^{\circ}$ Los estatutos sociales vigentes incorporados a escritura pública y, en su caso, los pactos relevantes que vayan a constar en documento público.

7. ${ }^{\circ}$ El proyecto de escritura de constitución de la nueva sociedad o, si se trata de una absorción, el texto íntegro de los estatutos de la sociedad absorbente o, a falta de estos, de la escritura por la que se rija, incluyendo destacadamente las modificaciones que hayan de introducirse.

8. ${ }^{\circ}$ La identidad de los administradores de las sociedades que participan en la fusión, la fecha desde la que desempeñan sus cargos y, en su caso, las mismas indicaciones de quienes vayan a ser propuestos como administradores como consecuencia de la fusión.

2. Si la sociedad no tuviera página web, los socios, los obligacionistas, los titulares de derechos especiales y los representantes de los trabajadores que así lo soliciten por cualquier medio admitido en Derecho tendrán derecho al examen en el domicilio social de copia íntegra de los documentos a que se refiere el apartado anterior, así como a la entrega o al envío gratuitos de un ejemplar de cada uno de ellos.

3. Las modificaciones importantes del activo o del pasivo acaecidas en cualquiera de las sociedades que se fusionan, entre la fecha de redacción del proyecto de fusión y la de la reunión de la junta de socios que haya de aprobarla, habrán de comunicarse a la junta de todas las sociedades que se fusionan. A tal efecto, los administradores de la sociedad en que se hubieran producido las modificaciones deberán ponerlas en conocimiento de los administradores de las restantes sociedades para que puedan informar a sus respectivas juntas. Esta información no será exigible cuando, en todas y cada una de las sociedades que participen en la fusión, lo acuerden todos los socios con derecho de voto y, en su caso, quienes de acuerdo con la ley o los estatutos pudieran ejercer legítimamente ese derecho. 
Los derechos de información de los representantes de los trabajadores, propios de los sistemas de democracia industrial, aun teniendo origen en el art. 129.2, en conexión con el 9.2, de la Constitución y siendo un instrumento imprescindible para que aquéllos puedan desarrollar las funciones que les son propias, implican una evidente limitación del derecho de dirección del empresario que también consagra la propia Constitución en su art. 38 y recoge el Estatuto de los Trabajadores en su art. 20. Por esa razón se trata de derechos que no son susceptibles de interpretación extensiva. Ya señaló el Tribunal Constitucional en su Sentencia de 29-2-1992 (RTC 1992\173), al examinar la Ley 2/1991 (RCL 1991\39), que «el legislador dispone de un amplio margen de maniobra que le permite crear medios adicionales de promoción de la actividad sindical pero también configurarlas y limitarlas y, en el futuro, modificarlas o suprimirlas (SSTC 39/1986 [RTC 1986139]; 9/1988 [RTC 1988\9]; 61/1989 [RTC 1989\61] y 127/1989 [RTC 1989\127])». Y en la de 22-4-1993 (RTC 1993\142) recordó que «estas fórmulas de participación quedan remitidas por el propio texto constitucional a la normativa legal (SSTC 37/1983 [RTC 1983\37), F. 2. ${ }^{\circ} ; 118 / 1983$ [RTC 1983\118], F. 4. y 39/1986, F. 4. ${ }^{\circ}$ ) de modo que el legislador tiene un notable margen de apreciación para determinar el grado de participación en la empresa que establezca y dentro de ello el de los derechos de información otorgados a los representantes del personal». Es evidente pues que el ejercicio del derecho de información no deberá interferir más de lo necesario en lo que es competencia del empresario, ni podrá superar, por ende, los límites fijados por la Ley o por el convenio colectivo que puede ampliarlos —el ET no contiene un catálogo cerrado o «numerus clausus» de derechos de información- como aquí ha ocurrido.

En relación con el art. 64.1.9. a). No es norma que faculte al comité para exigir de la empresa cualquier información que considere oportuna. Contemplado dicho apartado a la luz del total contenido del art. 64 cabe afirmar que el comité, para ejercer su labor de vigilancia del cumplimiento de las normas laborales, de Seguridad Social y empleo, así como el resto de los pactos, condiciones y usos de empresa en vigor, y las condiciones de seguridad e higiene en el trabajo [art. 64.1.9 a) y b) ET], habrá de contar con la información que consiga por sus propios medios - entre la que se encuentra, como recuerda el Tribunal Constitucional en su Sentencia 22-41993, la que puedan ofrecer «los correspondientes documentos de cotización» a los que siempre ha tenido acceso (art. 87.3, O. de 23-10-1986 [RCL 198613324 y RCL 1987\531); art. 95. 3, O. de 8-4-1992 [RCL 1992\903 y 1339]; y art. 90.2, O. de 22-2-1996 [RCL 19961705 y 1120]) —y con aquella otra que la empresa está obligada a entregarle. Entendiendo por tal sólo aquella que el legislador — que la ha detallado en los artículos 64.1, 39.2, 40.1, 41.2 y 44.1 ET-, y en su caso el pacto colectivo, han considerado necesaria y suficiente para que el comité pueda desempeñar con éxito las competencias que tienen reconocidas para la defensa, protección y promoción de los intereses de los trabajadores, sin que pueda exigir de la empresa un deber de información más extenso o intenso que los previstos en las normas laborales y convencionales. Y en ninguna de ellas se impone a la empresa la obligación de facilitar al comité los datos que éste exige.

En algunos supuestos, como en la STS 1 junio 2010 (RJ 2010\5933), se ha llegado a sostener que los RLT no tienen derecho a la información a que tienen derecho los trabajadores. Así, se acordó la denegación del derecho de los trabajadores a obtener el listado de plazas existentes en el Banco Bilbao Vizcaya, indi- 
cando denominación de la plaza, categoría profesional, ubicación, destino, oficina, y tipo de contratación a efectuar» por falta de cobertura legal o convencional: pues el art. 15.7 da derecho a los trabajadores pero no a sus representantes (¿?)

En relación al artículo 64.1 ET en el que, también, (fundamento de derecho tercero) la sentencia impugnada basa su decisión, al afirmar ya «muy concretamente» el derecho del comité de empresa a «recibir información.... sobre la celebración de nuevos contratos, con indicación del número de estos y de las modalidades y tipos de contrato que serán utilizados», debe indicarse que dicha norma, en su literalidad, preceptúa el derecho del representante de los trabajadores «a recibir información que les será proporcionada trimestralmente, al menos sobre la evolución general del sector económico al que pertenece la empresa, sobre la situación de producción y ventas. Así como las previsiones del empresario sobre la celebración de nuevos contratos con indicación del número de estos y las modalidades de contratación y tipos de contrato que serán utilizados, incluidos los contratos a tiempo parcial.....». Con claridad se deduce de este artículo que la competencia que, en materia de información, atribuye el artículo 64.1. ${ }^{\circ}$ ET al comité de empresa no es un deber de información sobre vacantes como el que se pretende en la demanda y se recoge, parcialmente, en la sentencia recurrida en relación con la existencia de vacantes en su totalidad y en todo el ámbito empresarial, con la expresión de la categoría, el puesto y de su ubicación territorial; no teniendo, por tanto, encaje la pretensión estimada parcialmente en el derecho tutelado por el repetido artículo 64.1 relativo al derecho del comité de empresa a recibir información sobre la celebración de nuevos contratos, la indicación de estos, y las modalidades y tipos de contratos a realizar o en relación con la evolución probable de empleo en la empresa.

Como crítica a esta sentencia, hay que decir que la información indebidamente denegada por el TS encuentra una cobertura clarísima en el art. 4.2 b) Directiva 2002/14: la información y la consulta sobre la situación, la estructura y la evolución probable del empleo en la empresa o en el centro de trabajo.

Además, a título de anécdota, el TS cita erróneamente la STC 251/05, cuando se refiere a la 281/05, para decir que «si bien el derecho de libertad sindical incorpora derechos de la actividad del sindicato, no obstante cuando estos derechos imponen cargas u obligaciones para el empresario es necesaria la existencia de una cobertura legal» Reconoce que la información debe transmitirse a los trabajadores y concluye que no hay habilitación legal, cuando la evolución probable de empleo en la empresa o centro debería incluir - cabalmente- el listado de plazas vacantes, indicando denominación de la plaza, categoría profesional, ubicación, destino, oficina, y tipo de contratación a efectuar.

\subsection{Concepto abierto: información necesaria para ejercer sus funciones constitucionalmente reconocidas}

Como apuntábamos al principio no ha faltado alguna sentencia que, si bien obiter dicta, ha apuntado hacia un concepto más flexible y finalista. 
Nos referimos a la STS 19 febrero 2009 (RJ 2009\1620) donde - a pesar de denegar la información solicitada - se admite que fuera de la ley y el convenio el Sindicato pueda justificar la necesidad de los datos solicitados para el cumplimiento de sus funciones

...está aquí acreditado que la empresa demandada ha entregado la copia básica de los contratos y ha facilitado la información de los salarios por categorías y departamentos, información que cumple suficientemente con las exigencias que al respecto establece el artículo 1 de la Ley 2/1991, de enero, que regula los derechos de información de los trabajadores en materia de contratación, en cuanto dispone este precepto que "con el fin de comprobar la adecuación del contenido del contrato a la legalidad vigente, esta copia básica contendrá todos los datos del contrato a excepción del número del DNI, el domicilio, el estado civil y cualquier otro que, de acuerdo con la Ley Orgánica $1 / 1982$, de 5 mayo, pudiera afectar a la intimidad personal», sin que el convenio colectivo de empresa aplicable amplíe en esta materia los derechos establecidos en dicha Ley, y sin que el Sindicato demandante haya expuesto algún tipo de concreta justificación, que hiciera necesario el conocimiento de los datos solicitados en relación con el ejercicio de las funciones que constitucionalmente tiene reconocidas.

\subsection{La sorprendente doctrina de la falta de necesidad de notificar a los representantes de los trabajadores los despidos individuales realizados en el marco de un despido colectivo}

Más recientemente, con ocasión de la reforma de 2012, se ha implantado la doctrina de que no procede la notificación a los RLT de las notificaciones individuales de los despidos realizados en el marco de un despido colectivo.

Sin embargo, tradicionalmente se había considerado que la información a los representantes de los trabajadores sobre los despidos objetivos económicos es una pieza esencial del sistema legal de control de la distinción institucional entre el despido colectivo y el objetivo. Sin una información de esta clase, que tiene necesariamente que centralizarse en la representación unitaria de los trabajadores, éstos tendrán importantes dificultades para conocer la situación de la empresa en orden a la correcta utilización del cauce del despido objetivo económico y, por tanto, será muy difícil acreditar la eventual superación de los límites cuantitativos.

Ahora, sin embargo, se considera que garantías formales que el ET ha introducido en los casos de despido objetivo (individual, plural) no se trasladan de manera absoluta, sino que existen determinados matices cuando se trata de extinciones contractuales enmarcadas en un despido colectivo. Por ello, se concluye, lka copia a los representantes de los trabajadores, por expreso mandato legal, solo procede entregarla en los supuestos del artículo 52.c)ET y no en los de despido colectivo. 
Así por ejemplo:

—STS 16 marzo 2016. núm. 228/2016 de 16 marzo (RJ 201612673)

A) El Ministerio Fiscal recuerda que un despido objetivo de carácter individual surge cuando concurre alguna de las causas previstas en el art. 51.1ET y la extinción afecta a un número inferior al establecido en el mismo. Si el número es superior ha de seguirse el procedimiento de despido colectivo y no será de aplicación lo que establece el 53.1.c) ET.

B) Aunque el expuesto encadenamiento de preceptos, con doble reenvío, puede suscitar alguna crítica compartimos la posición acogida por la sentencia recurrida y el Ministerio Público.

La literalidad de los artículos expuestos no arroja duda alguna que debiera resolverse invocando criterios teleológicos o analógicos. La copia del escrito de preaviso (que en realidad alude a la carta de despido) debe entregarse a los representantes de los trabajadores en el supuesto del despido objetivo (artículo 52.c), que es diverso del examinado en el caso, prototípico despido colectivo.

C) La STS 18 abril 2007 (RJ 2007, 3770) (rec. 4781/2005) reflexiona acerca del incumplimiento del requisito en cuestión en un supuesto de despido individual y manifiesta que "la concesión del preaviso puede realizarse en la comunicación, fuera de ella o no realizarse y además en sí mismo el preaviso no contiene ninguna información útil a efectos del control de las decisiones extintivas del empresario. Por ello, no tiene sentido establecer una obligación de comunicación del preaviso y hay que entender que la información debe referirse a la comunicación del cese, lo que, por lo demás, podría constituir una ampliación de los derechos de información del artículo 64 del Estatuto de los Trabajadores «. El supuesto es diverso del actual pero su recordatorio pone sobre la pista de que la finalidad perseguida por la comunicación (del cese, no del preaviso) en el caso de los despidos colectivos se ha llevado por el legislador (en concordancia con las exigencias comunitarias) a la fase previa de información y consultas.

La STS 11 junio 2014 (RJ 2014, 3940) (rec. 649/2013) reafirma lo dicho en ocasiones precedentes sobre la funcionalidad del requisito en estudio: "La información a los representantes de los trabajadores sobre los despidos objetivos económicos es una pieza esencial del sistema legal de control de la distinción institucional entre el despido colectivo y el objetivo. Sin una información de esta clase, que tiene necesariamente que centralizarse en la representación unitaria de los trabajadores, éstos tendrán importantes dificultades para conocer la situación de la 
empresa en orden a la correcta utilización del cauce del despido objetivo económico y, por tanto, será muy difícil acreditar la eventual superación de los limites cuantitativos». Sin que se aborde la cuestión que ahora nos ocupa, lo cierto es que se pone de relieve el sentido que posee la exigencia cuando se trata de despidos que no se han integrado en una reducción de plantilla colectiva. Como en ella se afirma "La finalidad de tal requisito es que dicha representación tenga conocimiento del despido que ha efectuado la empresa, en orden a la correcta utilización del cauce del despido objetivo».

D) Claro que puede ser razonable que los representantes legales de los trabajadores posean una información exacta de las extinciones contractuales que dimanan de un despido colectivo. De hecho, es usual que cuando el procedimiento de despido colectivo concluye con acuerdo se contempla la existencia de una Comisión de seguimiento, cual aquí sucede (cf. el HP 7.º). Probablemente la fiscalización del cumplimiento de las normas laborales (art. 64.7.a.1. ${ }^{\circ}$ ) requiere que se le informe de las extinciones producidas, lo que puede contribuir a erradicar criterios selectivos que sean discriminatorios o, en general, contrarios a Derecho.

Pero aquí no se trata de examinar esa dimensión institucional o colectiva de la representación legal de los trabajadores y su seguimiento de las extinciones adoptadas por la empresa sino de aquilatar las exigencias legales del despido derivado de un procedimiento colectivo, en cuanto acto de individualización.

Lo cierto es que las garantías formales que el ET ha introducido en los casos de despido objetivo (individual, plural) no se trasladan de manera absoluta, sino que existen determinados matices cuando se trata de extinciones contractuales enmarcadas en un despido colectivo. La copia a los representantes de los trabajadores, por expreso mandato legal, solo procede entregarla en los supuestos del artículo 52.c)ET y no en los de despido colectivo.

—STS 06 mayo 2016 (Recurso: 3667/2014)

Despido colectivo: Notificación a los representantes de los trabajadores de los despidos individuales realizados en el marco de un despido colectivo.

Las garantías formales que el ET ha introducido en los casos de despido objetivo (individual, plural) no se trasladan de manera absoluta, sino que existen determinados matices cuando se trata de extinciones contractuales enmarcadas en un despido colectivo. La copia a los representantes de los trabajadores, por expreso mandato legal, solo procede entregarla en los supuestos del artículo 52.c) ET y no en los de despido colectivo. 
Doctrina reiterada y seguida en: SSTS núm. 423/2016, de 12 mayo; núm. 387/2016, de 6 mayo; núm. 281/2016, de 7 abril; núm. 423/2016, de 12 mayo; núm. 303/2016, de 20 abril. SSTS 228/2016 de 08 marzo (rec. 832/2015) y $251 / 2016$ de 30 de marzo de 2016 (rec. 2797/2014).

Esta doctrina plantea unas cuantas cuestiones:

¿Cómo puede controlarse el cumplimiento de los criterios de selección de los afectados acordados entre empresa y RLT? ¿Cómo puede excluirse la necesidad de informar a los representantes de los trabajadores? La propia sentencia reconoce que "Probablemente la fiscalización del cumplimiento de las normas laborales (art. 64.7.a.1. ${ }^{\circ}$ ) requiere que se le informe de las extinciones producidas, lo que puede contribuir a erradicar criterios selectivos que sean discriminatorios o, en general, contrarios a Derecho».

¿Será improcedente un despido objetivo sin comunicación a los RLT y procedente un objetivo en el marco de un colectivo sin idéntica notificación?

¿Cumple este criterio doctrinal con lo que establece el art. 4.2 c) de la Directiva 2002/14?

c) la información y la consulta sobre las decisiones que pudieran provocar cambios sustanciales en cuanto a la organización del trabajo y a los contratos de trabajo, incluidas las previstas por las disposiciones comunitarias mencionadas en el apartado 1 del artículo 9.

La Directiva no marca unos umbrales, por lo que las medidas preventivas, las decisiones sobre cambios sustanciales de organización del trabajo y contratos no han de ser colectivas. Basta que se afecte a un contrato y se trata de decisiones que no sólo son de despido colectivo y transmisión de empresas (art. 9.1); sino que son cualquier otra decisión que suponga cambios sustanciales en la organización y en los contratos. Evidentemente el despido individual supone un cambio sustancial en los contratos, lo que determinar la obligación de informar de las extinciones conforme al art. 4.2c) de la Directiva.

Además, si el TS venía diciendo - y mantiene- que el art. 53.1c), la información a los representantes de los trabajadores sobre los despidos objetivos económicos, es una pieza esencial del sistema legal de control de la distinción institucional entre el despido colectivo y el objetivo, puesto que los RLT tendrán importantes dificultades para conocer la situación de la empresa en orden a la correcta utilización del cauce del despido objetivo económico y, por tanto, será muy difícil acreditar la eventual superación de los límites cuantitativos.

Ejemplo: si en una empresa de 99 trabajadores se acuerda despedir a 10 y la empresa termina despidiendo a 20 al falso amparo del acuerdo alcanzado en período de consultas ¿cómo van a controlarlo los RLT?, con la doctrina del TS en la mano. 


\subsection{El criterio restrictivo en el plano procesal}

El criterio restrictivo se ha trasladado al plano procesal, a la hora de configurar los requisitos de la casación.

Así, en la STS 29 marzo 2006. RJ 200613306, se dice que para apreciar la vulneración de los derechos de información del art64 ET garantizados al Comité intercentros por un precepto de un Convenio colectivo, no es suficiente alegar la vulneración del art. 64 ET sino que — además— hay que alegar la infracción del precepto del convenio:

BANCO DE ESPAÑA: impugnación de acuerdos de la Comisión Ejecutiva: competencia de la Jurisdicción Laboral; modificaciones organizativas y de condiciones de trabajo: información o consulta a los representantes de los trabajadores: innecesaria: supuestos que afectan al grupo directivo.RECURSO DE CASACION: cuestión nueva; infracción legal: inconcreción. Es verdad que el art. 27 del Convenio Colectivo del Banco de España, publicado en el BOE de 25 de octubre de 1990, otorga al Comité Nacional de Empresa de este Banco las competencias y facultades del art. 64 del ET. Pero también es cierto que, siendo esto así, este art. 27 del Convenio Colectivo mencionada viene a ser el precepto fundamental o clave, para que el art. $64-1-4 .^{\circ}-\mathrm{d}$ ) puede ser aplicable al Comité Intercentros citado. Por ello, teniendo en cuenta el carácter extraordinario del recurso de casación, para que pudiese prosperar la denuncia que se contiene en este motivo, era de todo punto obligado, que en tal motivo se alegase expresamente la infracción de dicho art. 27 del convenio. La sola mención en el del antedicho art. 641-4. ${ }^{\circ}-\mathrm{d}$ ) del ET no es suficiente, puesto que, como se viene explicando, este artículo no es de aplicación directa al Comité Intercentros, siendo aquel art. 27 el que determina tal aplicación, de lo que se desprende que para la correcta formulación de este motivo de casación era de todo punto obligado que se denunciase la infracción de dicho art. 27. No se hizo así habida cuenta que en este segundo motivo (ni en ningún otro punto o extremo del proceso) no se hace alusión ni mención alguno a ese artículo del convenio, lo que obliga a concluir que este motivo está defectuosamente construido, y tal defecto de formulacion produce también, por sí solo el decaimiento del motivo estudiado.

\subsection{Contraste entre el criterio de flexibilidad e instrumentalidad en la documentación a entregar en los despidos colectivos y el legalismo formalista en la interpretación de los derechos de información y consulta}

En materia de despidos colectivos brilla ya con luz propia el criterio de flexibilidad articulado en torno a un enfoque teleológico de las obligaciones que tiene el empresario en orden a entregar los documentos del art. 51.2 ET, a pesar de que el precepto es taxativo cuando dice que la comunicación a los RLT ya al a autoridad laboral deberá ir acompañada de una memoria explicativa de las causas del despido colectivo y de los extremos del art. 51.2 ET pfo 5.․, así como de la documentación contable y fiscal y los informes técnicos, todo ello en los términos que reglamentariamente se establezcan. Por su lado, el RD 1483/12 se expresa en iguales términos imperativos (vid. arts. 4-6). 
En efecto, a pesar del carácter taxativo de la ley, el TS realiza aquí una interpretación teleológica, ciertamente loable, pero incomprensiblemente asimétrica y desigualadora en relación con la finalidad que tiene la documentación prevista en el art. 64 ET, donde el rigorismo literalista le lleva a concluir que ningún documento que no figure en el art. 64 puede ser reclamado por los RLT, aunque el mismo sea relevante a las finalidades pretendidas de información y consulta.

Veamos este contraste en algunos ejemplos.

\subsubsection{Criterio flexible y finalista en despidos colectivos}

STS 27 mayo 2013 (RJ 2013/7656): en despidos colectivos ${ }^{35}$ :

En la misma se dice que cumple indicar con carácter previo a toda consideración sobre la documental aportada en el caso de autos,

que no todo incumplimiento de las previsiones contenidas en aquel precepto puede alcanzar la consecuencia de nulidad que se pueda desprender del art. 124 LRJS, sino tan sólo aquella que sea trascendente a los efectos de una negociación adecuadamente informada.

Y nos referimos a la "trascendencia» de la documental, porque entendemos que a pesar de los claros términos en que se expresan los arts. 6.2 RD 801/11 y 4.2 RD 1483/12 (RCL 2012, 1474) [el empresario «deberá aportar»], así como del 124 LRJS [se "declarará nula la decisión extintiva» cuando "no se haya respetado lo previsto» en el art. 51.2 ET, conforme a la redacción del RD-Ley 3/2012 ; y cuando «el empresario no haya... entregado la documentación prevista» en el art. 51.2ET, de acuerdo con el texto proporcionado por la Ley 3/2012 de todas formas la enumeración de documentos que hace la norma reglamentaria no tiene valor «ad solemnitatem», y no toda ausencia documental por fuerza ha de llevar a la referida declaración de nulidad, sino que de tan drástica consecuencia han de excluirse - razonablemente- aquellos documentos que se revelen «intrascendentes» a los efectos que la norma persigue [proporcionar información que consienta una adecuada negociación en orden a la consecución de un posible acuerdo sobre los despidos y/o medidas paliativas: art. 51.2ET]; con lo que no hacemos sino seguir el criterio que el legislador expresamente adopta en materia de procedimiento administrativo [art. 63.2 LRJ y PAC (RCL 1992, 2512, 2775 y RCL 1993, 246)] e incluso en la normativa procesal [art. 207.c) LRJS (RCL 2011, 1845)].

En esta misma línea ya se movía la STS 20/03/13 [rco 81/12 (RJ 2013, 2883)], cuando afirmaba que «... la principal finalidad del precepto [art. 6 RD 801/2011] es

35 SSTS 19 noviembre 2013 -rec. 78/2013 - 28 enero 2014 -rec. 46/2013 -, 17 febrero 2014 —rec. 32/2014_, entre otras muchas y más recientemente, STS 25/03/2015 Rec 245/2014 o STS 31 marzo 2016. Rec. 272/2015. En el mismo sentido y aplicando dicha doctrina, SSAN 01.04.2013 —núm. actuaciones 17/2013 - ; 08.07.2013 —núm. Actuaciones 180/2013-, 28.10.2013 —núm. actuaciones 284/2013—, 24.02.2014 —núm. actuaciones 493/2013-, 04.04.2013 —núm. actuaciones. 63/2013—, 30.05.2014—núm. actuaciones 13/2014— 12.06.2014 — núm. actuaciones 79/2014_, etc. 
la de que los representantes de los trabajadores tengan una información suficientemente expresiva para conocer las causas de los despidos y poder afrontar el periodo de consultas adecuadamente. En este sentido se orienta el artículo 2.3 de la Directiva 98/59/CE del Consejo de 20 de julio de 1998 (LCEur 1998, 2531) relativa a la aproximación de las legislaciones de los Estados miembros que se refieren a los despidos colectivos, para que ése periodo de consultas a que se refiere el artículo 2.1 , se proyecte, tal y como expresa el articulo 2.2 y como mínimo, sobre las posibilidades de evitar o reducir los despidos colectivos y de atenuar sus consecuencias...».

STS 3 noviembre 2015 (RJ 2015/5507). En MSCT:

Aunque es evidente que los artículos 40 y 41 ET (RCL 1995, 997) no delimitan específicamente cual es la información a entregar, tanto el artículo 64 ET (RCL 1995, 997) como la jurisprudencia de esta Sala (STS/4.a/Pleno de 27 de mayo de 2013 (RJ 2013, 7656) (rec. 78/2012) — con criterio reiterado en la STS/4.a/Pleno de 19 noviembre 2013 (rec. 78/2013 y SSTS de 24 de julio de 2015, Rec. 210/2014 y de 13 de octubre de 2015, Rec. 306/2014 (RJ 2015, 5212)) han precisado que, en estos supuestos, el contenido de la información será apropiado si permite a los representantes de los trabajadores preparar adecuadamente la consulta.

\subsubsection{Criterio literalista y rigorista en información y consulta del art. 64 ET.}

STS 9 octubre 2015 (RJ 2015\5665)

Reitera doctrina del concepto "taxativo o de numerus clausus» de la información prevista en el art. 64 ET. Acoge un concepto restrictivo, formalista y no finalista de la información (SSTS 20 de junio de 2012 (Rc 176/11 (RJ 2012, 9966)), STS de junio de 2010 (Rc 60/08) (RJ 2010, 5933) y de 19 de febrero de 2009 (6/2008) (RJ 2009, 1620), según la cual, la jurisprudencia recaída hasta la fecha no permite llevar el alcance de las materias acogidas al derecho de información más allá de los términos empleados por los preceptos que lo regulan. Reputa innecesaria una información (número de clientes desglosado por comunidad autónoma y provincia), que la propia sentencia reconoce que podría ser pertinente en supuestos de flexibilidad interna o externa).

Solicitud a la empresa de información trimestral a Delegados de Personal sobre el número de clientes desglosado por comunidad autónoma y provincia: desestimación: las empresas demandadas informan trimestralmente a los representantes de los trabajadores sobre la evolución general del sector económico; evolución reciente y probable de la actividad de la empresa; situación sobre la producción, que contiene el número global de instalaciones y servicios prestados por cada compañía mes a mes; situación sobre ventas y programas de producción; previsiones de nuevos contratos; previsión de horas complementarias por empleados a tiempo parcial; previsión de supuestos de contratación; absentismo, accidentes de trabajo, enfermedades profesionales e índices de siniestralidad y estudios de medio am- 
biente laboral y mecanismos de prevención, de todo lo cual es fácil deducir el número global de clientes a través de la suma del número de instalaciones y servicios. Por el contrario, no ha acreditado el Sindicato recurrente que la información desglosada por comunidades autónomas y por provincias sea imprescindible, o al menos conveniente para el desarrollo de su actividad sindical en el marco de los derechos de información, a la vista de la documentación que, según el factum de la sentencia, facilita trimestralmente la empresa a los representantes de los trabajadores. Por ello, termina diciendo la sentencia:

si las empresas promueven en el futuro medidas de flexibilidad interna o externa, deberán informar necesariamente a los representantes de sus trabajadores en los términos exigidos por los arts. 40, 41, 47, 51 y $82.3 \mathrm{ET}$, en cuyo caso podría ser pertinente informar, según sean los centros afectados, sobre los clientes globales de la empresa, por comunidades autónomas o por provincias, pero no hay razón para que se anticipe la información desglosada, cuando los representantes de los trabajadores disponen puntualmente [de ella] sobre la clientela global de la empresa, así como sobre su evolución mensual, lo que les permite hacerse una composición objetiva y solvente de la situación de las compañías, que les posibilitara anticipar los movimientos de la empresa y definir, en su caso, sus propias estrategias sindicales.

No es atendible la invocación de los recurrentes de que debe prevalecer una interpretación finalista del precepto controvertido, apoyándose en las sentencias de esta Sala, de 3 de mayo (RJ 2011, 4503) y 13 de octubre de 2011 (RJ 2011, 7718) (Rc 168/2010 y 210/2010), pues se refieren a supuestos diferentes al aquí examinado: La primera se refiere a que la empresa debe facilitar la información interesada por los delegados sindicales en los mismos términos que al Comité de Empresa, en virtud de lo dispuesto en el art. 64.7 del Estatuto y Convenio Colectivo de aplicación, y la segunda, se refiere a la información sobre reconocimiento de un derecho con origen en un convenio colectivo.

\section{Cuestiones de titularidad}

En este último capítulo analizaremos algunas cuestiones críticas relativas a la titularidad de los derechos de información que la doctrina del TS ha venido resolviendo.

\subsection{Las secciones sindicales mixtas en la Administración Pública}

En la STS 8 julio 2014 (RJ 201414521). (Ponente: Alarcón) se resuelve con atino y haciendo gala de un criterio más abierto, que el derecho de información en Secciones sindicales mixtas (funcionarios-laborales) corresponde al Sindicato con independencia de quién lo pida (funcionario o laboral) y el procedimiento de tutela de libertad sindical es el adecuado para reclamarlo 
La información como parte del contenido esencial de la libertad sindical tutelable por el proceso de los arts. 174-184 LRJS no es cierto que aquí se esté ventilando una cuestión de mera legalidad ordinaria. Por el contrario, el derecho que tienen los Sindicatos con suficiente representatividad en la empresa, como es el caso de CGT, a recibir determinadas informaciones (a través de los Delegados Sindicales que representan a la Sección Sindical de Empresa) les viene reconocido por el artículo 10.3,1. ${ }^{\circ}$ de la LOLS: «tener derecho a la misma información y documentación que la empresa ponga a disposición del comité de empresa»; o a la más específica que, en materia de Seguridad y Salud Laboral, deba la empresa proporcionar a los Delegados de Prevención, puesto que, en definitiva, estos no son otra cosa que los representantes de los trabajadores con funciones específicas en materia de prevención de riesgos en el trabajo» (art. 35.1 LPRL). Pues bien, la LOLS es, de acuerdo con el artículo $81 \mathrm{CE}$, la que contiene el desarrollo del derecho fundamental de libertad sindical consagrado en el artículo 28.1 CE y, por lo tanto, todos los derechos sindicales (y muy singularmente el derecho de acción sindical en la empresa: art. 8), competencias, facultades y garantías que en ella se contienen forman parte de ese derecho genérico (o macroderecho) de libertad sindical y gozan de un procedimiento especial de tutela como prescribe el artículo 13 de la LOLS: "Cualquier trabajador o sindicato que considere lesionados los derechos de libertad sindical (sic, en plural), por actuación del empleador, asociación patronal, Administraciones públicas, o cualquier otra persona, entidad o corporación pública o privada, podrá recabar la tutela del derecho ante la jurisdicción competente a través del proceso de protección jurisdiccional de los derechos fundamentales de la persona». Y ese proceso, en nuestro caso, no es otro que el regulado en los artículos 177 a 184 de la LRJS, que el sindicato demandante ha utilizado.

\subsection{Delegados de prevención}

STS 24 febrero 2016 (ROJ: STS 912/2016 - ECLI:ES:TS:2016:912) (Recurso: 79/2015) sobre los Derechos de Información y consulta el TS se pronuncia el derecho de información de los delegados sobre las investigaciones derivadas de accidentes de trabajo. Dicho derecho de información de los delegados de prevención tiene la misma extensión que la potestad informativa de la propia autoridad laboral en este ámbito, y, por otra parte, la investigación de accidentes de trabajo y enfermedades profesionales forma parte del proceso de evaluación de los riesgos laborales y el acceso a sus resultados forma parte del derecho de información sobre la evaluación de riesgos comprendido en el art. 23 LPRL, por lo que la autoridad laboral tiene derecho a acceder a tales investigaciones $\mathrm{y}$, por consiguiente también tienen derecho a ello los delegados de prevención.

\subsection{Sindicatos no son titulares, secciones sindicales sí}

En la STS 15 julio 2015 (ROJ: STS 3964/2015 - ECLI:ES:TS:2015:3964) (Recurso: 115/2014), se mantiene un criterio discutible sobre la titularidad, obviando que la Sección sindical no es sino una extensión o parte de la organización del Sindicato en la empresa. 
En este supuesto se dice que está acreditado que las peticiones de información nunca fueron efectuadas por los Delegados Sindicales, actuando en nombre y representación del Sindicato, sino directamente por éste. Y si ello, es así, no hay duda de la correcta aplicación de la doctrina constitucional y jurisprudencial que cita la sentencia de instancia, conforme a la que "el derecho de información a que se refiere el art. 64 del ET no tienen como titular o sujeto activo a los Sindicados. Y es que tampoco la LOLS establece como derecho del Sindicato la extensión de tal derecho al Sindicato, aunque si a los Delegados Sindicales» (STS 20-04-1998).

Esta doctrina no es ni mucho menos novedosa, y podemos encontrarla en otras resoluciones del TS, como la STS 20 abril 1998 (RJ 1998\3480), en el que la titularidad del derecho de información corresponde a los Delegados sindicales, pero no al Sindicato.

Esta Sala ya ha declarado que el derecho de información a que se refiere el artículo 64 del Estatuto de los Trabajadores no tiene como titular o sujeto activo a los Sindicatos. Y es que tampoco la Ley Orgánica de Libertad Sindical establece como derecho del Sindicato la extensión de tal derecho al Sindicato, aunque sí lo haga a los Delegados Sindicales, como después se verá. Valga, como antecedente doctrinal, la Sentencia de 22 junio 1995 (RJ 199515362), recaída en un conflicto colectivo promovido sobre derecho de información por el mismo Sindicato aquí actuante y contra la misma Empresa ahora recurrida. Sentencia que casó la condenatoria de instancia para absolver a la demandada y que fundaba la estimación del recurso en que la obligación de la empresa a facilitar información previa sobre los acoplamientos de personal debe referirse al Comité Provincial de Guipúzcoa y no a cada uno de los Sindicatos representados en el mismo. Y es claro, porque el invocado artículo 10.3.1 de la Ley Orgánica de Libertad Sindical no extiende la prevención del mencionado artículo 64 del Estatuto al Sindicato, sino únicamente a los Delegados sindicales de las Secciones establecidas por los afiliados a Sindicato que cuente con presencia en los órganos de representación unitaria de los trabajadores. Cuando se niega la información como derecho propio del Sindicato no se infringe ninguno de los preceptos alegados por el recurso.

\subsection{Exclusión de un sindicato del Derecho de información es vulnerar libertad sindical}

Este ha sido un criterio tradicional, conforme al que se ha considerado que la exclusión de un sindicato del derecho a recibir la información que se proporciona a otros es contrario a la libertad sindical.

Así, por ejemplo, la STS 8 julio 2010. RJ $2010 \backslash 6795$ en que se juzga contraria a la libertad sindical la conducta del Ministerio de Defensa consistente en excluir al sindicato USO de ciertas reuniones informativas constituye vulneración del derecho a la libertad sindical: 
la vertiente de la libertad sindical afectada es, el derecho a recibir la información relevante dispensada a otros sindicatos respecto de determinados planes de futuro del personal laboral al servicio del Ministerio en los año 2007 y siguientes.

1) el suministro de información relevante por parte de una entidad empleadora a los sindicatos representativos puede efectuarse o bien directamente, o bien a través de los delegados y representantes sindicales presentes en los comités de empresa en cumplimiento del artículo 10 de la Ley Orgánica de Libertad Sindical (RCL 1985, 1980) ; y 2) el acceso del sindicato a información relevante, en los términos precisados en las leyes, es un ingrediente del derecho a la actividad sindical, derecho este último que constituye, según jurisprudencia constitucional reiterada, la dimensión "funcional» del derecho complejo a la libertad sindical.

Pues bien, esta información relevante se ha sustraido al sindicato actor, según los hechos probados $10^{\circ}$ y $2 .^{\circ}$ de la sentencia recurrida, al proporcionarse la misma al personal del Ministerio de Defensa exclusivamente a través del canal de la subcomisión delegada en dicho departamento de la comisión paritaria del convenio colectivo, en la que aquél no tiene presencia, negándosela en cambio a los comités de empresa de representación unitaria, organismos en los que sí está representado USO. Estos organismos han de ser también, por ministerio de la ley [art. 64.1.1. ${ }^{\circ}$ y $4 .^{\circ}$ a) ET (RCL 1995, 997)], receptores de informaciones relevantes sobre los planes, perspectivas y decisiones de empleo en las empresas y centros de trabajo; recepción de información que es el presupuesto lógico de la transmisión de la misma por parte del sindicato a sus afiliados y a los trabajadores de la empresa.

\subsection{Delegados sindicales de sindicatos que tienen representación en el comité de empresa}

La STS 29 marzo 2011. RJ 2011\3687, en interpretación del art.10.3.1 LOLS considera que se trata de un derecho autónomo de los delegados sindicales que no formen parte del comité de empresa a tener acceso a la misma información y documentación que la empresa ponga a disposición del órgano de representación unitaria, aunque se trate de sindicatos que tengan representación en tal órgano.

No obstante hay que apuntar que en dicha resolución se contiene una doctrina errática sobre la carga de la prueba, cuando se dice:

En relación con las estadísticas sobre el índice de absentismo y las causas, los accidentes de trabajo y enfermedades profesionales y sus consecuencias, los índices de siniestralidad, los estudios periódicos o especiales del medio ambiente laboral y los mecanismos de prevención que se utilicen, la Administración informó a los delegados sindicales que ahora sostienen la demanda que no se disponía de tales datos. Con independencia de que existe ciertamente ese derecho de información en el artículo $64.2 \mathrm{~d}$ ) ET, ante la negativa de que se disponga realmente de tales datos por la demandada, correspondía a los actores acreditar lo contrario, lo cual ciertamente no se produjo, razón por la que no cabe apreciar esa vulneración del derecho de libertad sindical en este punto. 


\subsection{Sección sindical de sindicato no firmante del convenio}

En la STS 30 noviembre 2009 (RJ 2009\8029) se contempla un supuesto de denegación de derechos informativos: delegado sindical de sindicato más representativo no firmante de convenio colectivo; indemnización por daños morales (3000 EUROS). Se estima el derecho de las secciones sindicales a la misma información que el Comité de empresa abarca los derechos de información previstos en Convenio colectivo, aunque la Sección sindical no sea firmante de dicho convenio.

... el deber de información sobre las materias arriba descritas, incluso aunque esas mismas obligaciones estuvieran contempladas en la norma convencional (lo que, en este caso, ni tan siquiera ha sido objeto de discusión), no constituye «administración del convenio" sino un derecho de los delegados sindicales que no formen parte del comité de empresa, en los términos expresamente previstos por el art. 10.3.1. ${ }^{\circ}$ de la Ley Orgánica de Libertad Sindical («Tendrán acceso a la misma información y documentación que la empresa ponga a disposición del comité de empresa»). Además, el reconocimiento judicial de tales derechos en favor de esos delegados no entraña ningún trato negativo respecto a los Sindicatos que suscribieron el convenio, o incluso respecto a otros Delegados o Secciones Sindicales que pudieran estar constituidas, por la sencilla razón de que, tanto éstas como aquéllos, al margen de la propia regulación convencional, lo tienen así mismo reconocido por la referida normativa orgánica en términos de igualdad respecto al Comité de Empresa, y también está fuera de discusión que los datos e información en cuestión sí fueron facilitados a dicho Comité. Otro problema muy distinto es que el Sindicato actor pueda no tener derecho a formar parte de las Comisiones que se constituyan para la administración y aplicación del Convenio Colectivo, pero no es éste el derecho que la demanda denuncia como infringido sino el de obtener la información a la que alude el tan repetido art. 10.3.1. ${ }^{\circ}$ de la LOLS. Por último, en fin, tampoco se trata de comprobar si ha existido o no un trato discriminatorio del Sindicato demandante, lo que hubiera exigido por su parte la aportación de algún elemento indiciario al respecto; insistimos: el objeto principal de la denuncia es - y no es una cuestión menor- el incumplimiento del mencionado precepto de la LOLS.

Como crítica a tal resolución, en la misma se plantea la cuestión de si las consecuencias jurídicas de la infracción son - conforme al art. 8.2 de la Directiva 2002/14 - efectivas, proporcionadas y disuasorias. En este sentido se razona para conceder 3000 euros en lugar de los 6000 pedidos que:

teniendo en cuenta la auténtica realidad de lo sucedido; que se trata de una forma de proceder que afecta a todos los Sindicatos que no firmaron el Convenio Colectivo en vigor; y finalmente, que parte de las denuncias hechas valer no suponen en realidad, una violación de su derecho de libertad sindical [recordemos que la demanda sólo es estimada en parte, no sólo en lo referente a la cantidad objeto de condena por dańos morales sino también respecto a las conductas empresariales que se decían constitutiva de vulneración del derecho fundamental], el monto indemnizatorio ha de moderarse y quedar cifrado en tres mil euros. 
En fin, la STS de 11 marzo 1999 (RJ 1999 2912), razona que la sección sindical tiene el mismo derecho informativo que el Comité de empresa cuando no forme parte de aquel, pero no uno distinto ni mayor, por lo que no se incluyen los TC1 y TC2.

... la sección sindical que promueve el conflicto colectivo recibe de la empresa la misma información que ésta facilita a la representación unitaria de los trabajadores, motivo que la sentencia recurrida tomó en consideración para fundamentar su fallo, acomodado a las reglas del artículo 10.3.1 de la Ley Orgánica de Libertad Sindical, que como vulnerado se denuncia en el recurso. Lo que dispone este precepto es que los delegados sindicales en el supuesto de que no formen parte del comité de empresa, tendrán «acceso a la misma información y documentación que la empresa ponga a disposición del comité de empresa, estando obligados los delegados sindicales a guardar sigilo profesional en aquellas materias en las que legalmente proceda». Lo que garantiza el precepto a los delegados sindicales es el acceso a la misma información y documentación que la empresa ponga a disposición del comité, de manera que si la entidad demandada, tal como ha quedado probado, facilita a la sección sindical la misma información que pone al alcance de los representantes unitarios, queda cumplida la regla citada anteriormente; pero hay más: el artículo 64.9 a) del Estatuto de los Trabajadores, que como violado se invoca en el recurso, no ampara una información tan extensa como la solicitada en la demanda, limitándose la norma a reconocer en favor del comité de empresa una labor «de vigilancia en el cumplimiento de las normas vigentes en materia laboral, de Seguridad Social y de empleo, así como el resto de los pactos, condiciones y usos de empresa en vigor, formulando, en su caso, las acciones legales oportunas ante el empresario y los organismos o Tribunales competentes», pero sin hacer alusión alguna a la obligación de la empresa de facilitar cuadrantes de servicio o programación de los mismos, con sus eventuales variaciones, ni los TC1 y TC2 que es lo que se pide aquí.

\section{Límites de los derechos de información y consulta}

El respeto a la ley y a los derechos de los demás es uno de los fundamentos del orden político y la paz social que proclama el art. 10.1 CE, que expresa con claridad que en un Estado social y democrático de derecho los derechos subjetivos son esencialmente limitados; o dicho de otra forma, no existen derechos ilimitados (Vid STC 120/90) ${ }^{36}$.

Pero a parte de esta limitación esencial, interna a todo derecho, dimanante de su lógica coexistencia con los derechos de los demás, existen otros límites, los externos.

36 Salvo algunos supuestos concretos, como el derecho a no sufrir torturas (art. 15 CE) (vid. STC 151/97). 
En efecto, los límites de los derechos pueden concebirse desde dos planos: límites externos (límites en sentido propio) o límites internos (delimitación).

Los externos son reducciones contingentes impuestas sobre su objeto por quien goza de habilitación para ello. Son externos, contingentes y constitutivos (ej. art. 28: posibilidad de exceptuar del derecho de sindicación a las Fuerzas o Institutos armados o de regular las peculiaridades de su ejercicio para los funcionarios públicos).

Los límites internos consisten en la delimitación necesaria del derecho, interpretando quiénes son sus titulares, el objeto o el contenido, a través de la interpretación, por lo que los límites internos o delimitación es siempre una operación necesaria y previa a la limitación. Para limitar un derecho éste debe estar previamente delimitado; o dicho de otra forma, para reducir o afectar el contenido de un derecho, primero debemos delimitar este contenido.

Por tanto, en relación a los límites podemos hablar de limitar (afectar contenido ya definido) o delimitar (definir el contenido) (Villaverde et al., 2004).

En el seno de la relación laboral, el Tribunal Constitucional ha tenido ocasión de definir los límites y contenido de las libertades públicas en sus SSTC $81 / 83,120 / 83,137 / 90$, y 126/90, y en todas ellas proclama rotundamente el principio del inevitable entendimiento de las facultades que en ellas se integran, como poderes subjetivos que no carecen de límites, sino que por el contrario, están sometidos tanto a la restricción representada por los derechos ajenos protegidos por la Ley e igualmente respetables, cuya agresión en el pretendido ejercicio de libertades públicas es ilegal como a la que representan los módulos en que por imperativo del derecho común, debe mantenerse siempre en el ejercicio de cualquier situación de poder jurídico, particularmente la buena fe y la condición social de dicho ejercicio, según prescribe el artículo 7.1 y 2 del Código Civil, es decir, un límite exógeno impuesto por las prescripciones positivas que definen los márgenes representativos del mínimo de convivencia en la paz social y plenitud del resto de los derechos fundamentales, que, como las libertades ajenas a la dignidad de todos, también están protegidas al mismo nivel, por debajo del cual se frustra la plenitud de todos estos valores y se imposibilita su desarrollo; y un límite endógeno, impuesto por la esencia del concepto mismo de derecho, ontológicamente incompatible con el abuso, el daño de los bienes sociales o el fraude de los fines del ordenamiento (Vid STSJ Catalunya n. ${ }^{\circ} 3907 / 07$ de 24 mayo 2007; Recurso 260/2007).

Sentadas estas premisas, en este epígrafe nos centraremos en los límites internos, en «delimitar» los derechos de información, audiencia y consulta, fundamentalmente precisando sus contornos cuando entran en conflicto con otros derechos. En efecto, la interpretación de estos derechos, exige el examen de sus 
límites lógicos o inmanentes, derivados de su coexistencia con otros derechos, con lo que pueden y suelen entrar en liza.

Por tanto, trataremos los límites internos o la delimitación de los derechos de información, abordando el estudio en función de la fuente que contempla el derecho o poder con el que coexisten los derechos de información.. Así, distinguiremos entre los límites constitucionales y los límites estatutarios (Monereo, 1992: 270-331), partiendo de que los derechos de información, consulta y participación son derechos de configuración legal y que, por tanto, es el legislador en cada momento el que perfila su titularidad y contenido, hallando como límites las normas internacionales (ej. Convenio 135 OIT) o las supranacionales (ej. Directiva 2002\14).

\subsection{Límites constitucionales al derecho a la información}

Hay que destacar como derechos y normas constitucionales que limitan los derechos de información, audiencia y consulta: el derecho al honor y a la intimidad (art. $18 \mathrm{CE}$ ), así como el derecho a la protección de datos (art. 18.4 CE y LO 15/99).

Por otro lado, como límites inherentes al derecho que se ejercita y dado que se suele informar y opinar de forma indistinta, habrá que distinguir entre libertad de expresión (cuyo objeto son ideas u opiniones) de libertad de información (cuyo objeto son hechos o acontecimientos), pues sus limites internos son diversos.

En este sentido, la libertad de expresión e información es, en sustancia, un único derecho proclamado en los art. 20 de la Constitución Española y en el art. 10 del Convenio Europeo de Derechos Humanos, cuyo régimen jurídico varia según prevalezca la divulgación de hechos o la emisión de juicios de valor de carácter subjetivo, pues mientras en el primer caso se le impone constitucionalmente el requisito de veracidad, este atributo no es predicable de las opiniones personales que podrán ser razonables o estúpidas, pero no verdaderas o falsas. Sucede, sin embargo, que ambos supuestos no se presentan de forma nítida y, como recuerda el Tribunal Constitucional (STC de 192/1999), "en los casos reales que la vida ofrece, no siempre es fácil separar la expresión de pensamientos, ideas y opiniones de la simple narración de unos hechos, pues a menudo el mensaje sujeto a escrutinio consiste en una amalgama de ambos».

En cuanto a la veracidad, hay que destacar de la misma que cuando una información facilitada a terceros por el Comité viene precedida de una conducta de ocultación de información por la empresa, ignorando las previsiones del art. 64.1. ${ }^{\circ}$ del Estatuto de los Trabajadores, la doctrina ha declarado que no puede exigir después que las cifras manejadas por los representantes de los trabajadores sobre la evolución del empleo en la empresa gozaran de una rigurosa y total exactitud, pues aunque así no fuera no por ello quedarían privados de pro- 
tección ya que, como hace notar la doctrina constitucional, el requisito de la veracidad hay que predicarlo más que de la información del informador y «... cabe que, pese a ello, la información resulte inexacta o errónea, lo que no puede excluirse totalmente, pero la información rectamente obtenida y difundida es digna de protección (STC 6/1988 [RTC 1988, 6], F. 5) aunque su total exactitud sea controvertible o se incurra en errores circunstanciales que no afecten a la esencia de lo informado» (STC de 25 de febrero de 2002, núm. 52/2002 [RTC 2002, 52]).

\subsubsection{Derecho al honor}

El derecho al honor se reconoce en el art. $18 \mathrm{CE}$, y protege el aprecio social, la buena fama, la reputación y la autoestima de toda persona. Es el derecho a que otros no condicionen negativamente la opinión que los demás han de formarse sobre nosotros (STC 49/01). Corresponde a todos ser humano, por estar íntimamente vinculado con la dignidad humana y también a las personas jurídicas (SSTC 139/95 y 183/95) (Díaz, 2005: 299 y ss.).

El art. 20.3. CE establece como límite interno positivo al derecho de información y expresión, entre otros el derecho al honor.

El derecho al honor, en efecto, colisiona frecuentemente con las libertades de información y expresión, que se ejercitan cuando se llevan a cabo los derechos de información activa y de expresión por los representantes de los trabajadores o sindicales. En este sentido, el ET reconoce en su art 68 d) el derecho de los representantes unitarios a expresar con libertad sus opiniones en las materias concernientes a la esfera de su representación, pudiendo publicar y distribuir,sin perturbar el normal desenvolvimiento del trabajo, las publicaciones de interés laboral, o social, comunicándolo a la empresa.

Muestra máxima de esta colisión en el plano legal, es que el ET considera como infracción laboral susceptible de despido las ofensas verbales o físicas al empresario o a las personas que trabajan en la empresa o a los familiares que convivan con ellos art. 54.2c) ET).

En el contexto de la relación laboral el derecho a la información y a la libertad de expresión han de considerarse doblemente modulados por el derecho al honor y por a buena fe en el contrato de trabajo.

Hechas estas consideraciones, la doctrina jurisprudencial sobre el conflicto derechos de información $v$ s derecho al honor puede resumirse como sigue (STS 20 abril 2005, Recurso 6701/2003) ${ }^{37}$ :

37 En esta sentencia se declaró procedente el despido de miembros del comité de empresa por $\mathrm{CCOO}$ en período preelectoral, por difundir un panfleto en que se vierten las siguientes expresiones: "dirigidas a consejeros, vocales, directores de centro, jefes de personal, accionistas y demás fauna 
1) la celebración de un contrato de trabajo «no implica en modo alguno la privación para el trabajador de los derechos que la Constitución le reconoce, entre ellos el derecho a difundir libremente los pensamientos ideas y opiniones (art. 20.1.a CE)» (STC 204/1997 [RTC 1997, 204] y las que en ella se citan), por cuanto que las empresas «no forman mundos separados y estancos del resto de la sociedad» (STC 88/1985 y las muchas que reproducen esta máxima);

2) «la transmisión de noticias de interés sindical, el flujo de información entre el sindicato y sus afiliados... constituye un elemento esencial del derecho fundamental a la libertad sindical» (STC 94/1995 [RTC 1995, 94]);

3) más concretamente, la denuncia de hechos de relevancia pública, efectuada a través de medios adecuados y de forma proporcionada, por parte de los trabajadores o sus representantes, puede estar amparada por el ejercicio de los derechos fundamentales de libertad sindical y libertad de expresión (SSTC 126/1990 [RTC 1990, 126], 6/1995 [RTC 1995, 6], 186/1996 [RTC 1996, 186], 57/1999 [RTC 1999, 57] y 90/1999 [RTC 1999, 90]);

4) no obstante, el complejo de derechos y obligaciones que genera el contrato de trabajo modula el ejercicio de los derechos fundamentales, puesto que la buena fe en esta relación contractual comporta un «límite adicional al ejercicio de la libertad de expresión» (STC 241/1999 [RTC 1999, 241]), de donde se desprende que manifestaciones que incluso en otro contexto pudieran ser legítimas, no tienen por qué serlo necesariamente en el ámbito de dicha relación (SSTC 120/1983 [RTC 1983, 120] y 4/1996 [RTC 1996, 4], entre otras muchas); y 5) con carácter general, «el ejercicio de la libertad de expresión — también el del derecho a la información- no puede justificar sin más el empleo de expresiones o apelativos insultantes, injuriosos o vejatorios que exceden del derecho de crítica y son claramente atentatorias para la honorabilidad de aquel cuyo comportamiento o manifestaciones se critican» (STC 204/1997 [RTC 1997, 204]).

En este sentido, se ha considerado contrario al derecho al honor, por constituir ofensa verbal, la difusión por un miembro del Comité de empresa de un

\footnotetext{
(que) pasaban ante nosotros»: a) "mafias fascistas que controlan la empresa»; b) «el capo di tutti capi se reunía con la familia para repartir los territorios y los esbirros custodiaban la fortaleza, realmente era una visión de Chicago años 20»; c) "al otro lado estaban los terroristas de cuello blanco que campan a sus anchas por la empresa y que utilizan cualquier medio para seguir manteniendo el estado de terror que impera en la empresa"; d) "a los únicos que echamos en falta en el sarao fue a los pistoleros a sueldo de FASGA y FETICO" (siglas de sindicatos con implantación en la empresa); y e) "banda terrorista que es el Corte Inglés". La rúbrica o titular de la hoja distribuida es "Junta de accionistas: demócratas y terroristas"; y la invitación con la que concluye plantea de nuevo la disyuntiva "itú decides el bando!: con los demócratas o con los terroristas».
} 
escrito en el que se hacen públicos los nombres de nueve trabajadores, a los que se tacha de faltos de ética y compañerismo por prestarse a declarar en los juicios a favor de la empresa y se les tilda de defensores de un sistema de represión y chantaje utilizado por la empresa, calificando el suyo como un «sucio papel» y afirmando que se haría lo mismo con otros que se prestaran a declarar $^{38}$.

Para terminar, el deber del empresario de informar al Comité de empresa de las sanciones impuestas por faltas muy graves, previsto en el art. $64.4 \mathrm{c}$ ) ET, no se ha considerado que vulnere el derecho al honor del sancionado, como ha dicho la STS de 26 de noviembre de 1987 (RJ 1987\8692).

\subsubsection{El derecho a la intimidad}

$\mathrm{El}$ art. $18 \mathrm{CE}$ reconoce el derecho a la intimidad personal y familiar, que en el art. 20.4 CE se cita como un límite concreto de las libertades de información y expresión.

A nivel estatutario, el art .4.2 e) ET reconoce el derecho a la intimidad de los trabajadores en la relación de trabajo.

Son numerosos los conflictos con el derecho de la intimidad de los trabajadores en el marco de la relación laboral, en particular en el ámbito del ejercicio de la potestad de control del cumplimiento de la prestación por parte del empresario (art. 20.3 ET) ${ }^{39}$.

Sin embargo nos vamos a ceñir, por exigirlo así el guión, a los supuestos de colisión entre los derechos de información de los representantes de los trabajadores y el derecho a la intimidad.

En este ámbito se ha suscitado el problema de si vulneraba el derecho a la intimidad de los trabajadores la información que recibe el comité de empresa sobre copias del contrato, retribuciones, y demás datos profesionales.

En cuanto a las retribuciones, el TC en STC 142/93 ya dejó claro que la información a los representantes de los trabajadores de las retribuciones de éstos no lesiona su derecho a la intimidad. Así lo ha entendido también el TS en STS de 19 febrero 2009, Recurso 6/2008, en que concluye que la retribución o salario no es un dato de carácter personal ni íntimo susceptible de reserva para salvaguardar el respeto a la intimidad. Se trata de un elemento

38 STSJ Catalunya núm. 3907/2007 de 24 mayo, Recurso 260/2007.

39 Vid. SSTC 186/00 sobre juicio de proporcionalidad para la restricción de derechos fundamentales del trabajador en el supuesto de instalación de videocámaras. Vid SSTS 26 septiembre de 2007 (Recurso 966/2006) sobre uso de medios y herramientasm informáticas de la empresa por el trabajador y control de su actividad laboral. 
esencial del contrato de trabajo, de naturaleza contractual, laboral y profesional, no siendo necesario recabar el consentimiento previo del trabajador individual para que los representantes sindicales puedan acceder, en su caso, a dicho dato.

Más recientemente, la STS 3 mayo 2011, Recurso 168/2010, se ha pronunciado en el sentido de que la intimidad del trabajador no comprende las retribuciones que de su trabajo, por pertenecer éstas a las relaciones sociales y profesionales que el trabajador desarrolla fuera de su ámbito personal e íntimo. En parecido sentido, la SAN núm. 105/2010 de 2 noviembre; procedimiento n. ${ }^{\circ}$ 162/2009; declaró que no afecta a la intimidad la información detallada, distribuida por ańos y comprensiva del importe económico total y del número de trabajadores beneficiarios, desglosadas por cada uno de los niveles, funciones y grupos profesionales así como el total de las cuantías abonadas y correspondientes a cada nivel y grupo profesional por este concepto, en el Banco de España.

En cuanto a la copia básica del contrato, incide en el ámbito de la intimidad los datos relativos al DNI y fecha de nacimiento de los funcionarios inscritos en la bolsa que permite acceder al complemento de productividad ${ }^{40}$.

25. STS 21 diciembre 2015 Recurso: 56/2015 | Ponente: (López de la Serrana)

Resumen: Información y consulta: la conducta de la demandada consistente en no facilitar a los delegados sindicales de U.G.T. que no forman parte del Comité de Empresa la información solicitada, consistente en copia actualizada de la bolsa de trabajo de determinadas categorías profesionales de auxiliares, ayudantes y técnicos especialistas. constituye una violación del derecho a la libertad sindical de los mismos. El art. 10-3-1. ${ }^{\circ}$ de la Ley Orgánica 11/1985 desarrolla el derecho fundamental (art. 28 de la Constitución) a la libertad sindical, una de cuyas manifestaciones consiste en el derecho a recibir los delegados sindicales la misma información que se debe facilitar, conforme al artículo 64 del E.T,. a los miembros del comité de empresa, aunque no formen parte de este comité

Protección de datos de carácter personal: no se infringe por la cesión de los datos consistentes en copia actualizada de la bolsa de trabajo de determinadas categorías profesionales de auxiliares, ayudantes y técnicos especialista a la Sección sindical, pues la LO 15/99 dispone en su art. 6.2 que no será preciso el consentimiento del interesado cuando los datos personales «se refieran a las partes de un contrato o precontrato de una relación negocial, laboral o administrativa y sean necesarios para su mantenimiento o cumplimiento", cual ocurre en el presente caso en el que en la Bolsa de Empleo solo consta la relación de los candidatos por orden de puntuación, (Anexo IX, base 9. ${ }^{\text {a }}$ del Convenio Colectivo y Orden de la Consejería de Justicia y Administraciones Públicas de la Comunidad de Madrid de 11 de junio de 2002 publicada en el BOCM de 18 de junio de 2002). Por ello, aparte que al

40 STSJ CONT de 16 de febrero de 2004 (Recurso de apelación n. ${ }^{\circ}$ 108/2004). 
resultado final de las pruebas debe darse publicidad, resulta que el tratamiento que haga de la lista la sección sindical, obligada a guardar sigilo, viene limitado a comprobar si la recurrente al hacer llamamientos para las nuevas contrataciones respeta el orden impuesto por las bolsas de empleo al efecto, actuación en favor de los trabajadores en lista de espera (precontrato) que viene excepcionada por el citado artículo 6-2 de la L.O. 15/1999.

\subsubsection{Derecho a la protección de datos. Doctrina de los Tribunales y criterios de la AEPD}

El conflicto entre el DPDP y los derechos de información y consulta es una fuente inagotable de resoluciones judiciales; unas veces por el excesivo celo de las empresas, que ven en la protección de datos un fiel aliado para ocultar a los representantes unitarios o sindicales datos relevantes para el ejercicio de su función; otras veces porque dichos representantes se exceden en sus funciones y quieren conocer datos respecto de los que existen derechos fundamentales de los trabajadores que los ponen a salvo de cualquier transmisión sin su consentimiento.

Con carácter general, la doctrina se ha pronunciado en el sentido favorable a los derechos de información y consulta, máxime porque en el ámbito del Derecho del Trabajo es reiterada la doctrina que dice en relación a la necesidad de que el trabajador preste su consentimiento para la cesión de datos, por ejemplo sobre retribuciones que «...el principio de autonomia de la voluntad "aparece fuertemente limitado en el Derecho del Trabajo, por virtud, entre otros factores, precisamente del principio de igualdad» [STC 34/1984 F. 2. ${ }^{\circ}$ ], y que por ello es constitucionalmente justificable el virtual sacrificio de la esfera de lo individual en función de los intereses colectivos tutelados por la representación del personal, lo cual, como ya ha tenido ocasión de afirmar el TS, "no sólo no es incompatible con ámbitos de libertad personal, sino que los asegura actuando como garantia básica de situaciones jurídicas individualizadas y contribuyendo decisivamente tanto a la mejora de las condiciones de trabajo y de vida de los trabajadores como al bienestar social general» (STC 78/1985 [RTC 1985, 78], fundamento jurídico 6. ${ }^{\circ}$ ), señalando, asimismo que: «Por otro lado, la autonomía privada está sometida en el Derecho del Trabajo a límites estrictos, también de relevancia constitucional, como, por ejemplo, la probibición de no discriminación [STC 128/1987 (RTC 1987, 128), fundamento juridico 3.o], que permite justificar un acceso a cláusulas contractuales, especialmente las de carácter retributivo, dada además la prohibición específica que establece el art. 35.1 CE, in fine» (vid. STS 3 mayo 2011. RJ 2011 4503). El conflicto al que aludimos ha encontrado su plasmación a todos los niveles: europeo, constitucional y de jurisdicción ordinaria, por lo que trataremos de sistematizarla en torno al TJUE, TC, TS, AN y AEPD, sin ánimo exhaustivo. 


\subsubsection{Doctrina TJUE}

Tanto el TC como el TS han considerado que los datos relativos a las retribuciones no se integran dentro del contenido del derecho a la intimidad.

Esta tesis, sobre todo cuando de empleados públicos se trata, ha sido seguida también por el TJUE, quien además ha considerado que la divulgación de las retribuciones de los empleados públicos y de sus nombres puede ser adecuada y proporcionada al legítimo fin de la buena gestión de los recursos públicos (STJUE 20 de mayo de 2003. Asuntos C-465/00, C-138/01 y C-139/01 Rechnugshof ${ }^{41}$.

\subsubsection{Doctrina TC}

El TC, en su ATC 29/2008 de 28 enero (RTC 2008\29 AUTO), se pronunció sobre la correcta denegación a representante sindical en el ámbito de la Administración pública y al amparo del art. 9 de la Ley 9/87 de una solicitud de cesión masiva de datos sobre ocupación de empleados, puesto que el art. 9 Ley 9/87 no incluye en el contenido de dicha facultad el conocimiento de todos los datos de las situaciones profesionales de los empleados públicos, esto es, el art. 9 de la Ley 9/1987 no contempla la hipótesis del suministro de una información generalizada e indiscriminada de todos los aspectos relativos a la lista de puestos de trabajo de un determinado organismo público, ni, mucho menos, de determinados datos que afecten a las situaciones personales e individuales de todos y cada uno de los funcionarios públicos que los ocupen.

\subsubsection{Doctrina $T S$}

En su STS 21 diciembre 2015 (RJ 2015।6219), ha considera que la información a una Sección sindical sobre la lista de miembros de las bolsas de empleo para comprobar que se guarda el turno de llamamientos por orden de puntuación, no viola la protección de datos, por que resulta que el tratamiento que haga de la lista la sección sindical, obligada a guardar sigilo, viene limitado a comprobar si la recurrente al hacer llamamientos para las nuevas contrataciones

${ }^{41}$ El TJUE declara que: «1) Los artículos 6, apartado 1, letra c), y 7, letras c) y e), de la Directiva 95/46/CE del Parlamento Europeo y del Consejo, de 24 de octubre de 1995, relativa a la protección de las personas físicas en lo que respecta al tratamiento de datos personales y a la libre circulación de estos datos, no se oponen a una normativa nacional, como la controvertida en los asuntos principales, siempre que se demuestre que la amplia divulgación no sólo del importe de los ingresos anuales, cuando éstos superan un limite determinado, de las personas empleadas por entidades sujetas al control del Rechnungshof, sino también de los nombres de los beneficiarios de dichos ingresos, es necesaria y apropiada para lograr el objetivo de buena gestión de los recursos públicos perseguido por el constituyente, extremo que ha de ser comprobado por los órganos jurisdiccionales remitentes.

2) Los artículos 6, apartado 1, letra c), y 7, letras c) y e), de la Directiva 95/46 son directamente aplicables, en el sentido de que un particular puede invocarlos ante los órganos jurisdiccionales nacionales para evitar la aplicación de normas de Derecho interno contrarias a dichas disposiciones." 
respeta el orden impuesto por las bolsas de empleo al efecto, actuación en favor de los trabajadores en lista de espera (precontrato) que viene excepcionada por el citado artículo 6.2 de la LOPD.

Por otro lado, en la STS 3 mayo 2011 (RJ 2011\4503), el TS mantiene la línea de que la retribución o salario no es un dato personal ni íntimo susceptible de reserva para salvaguardar el respeto a la intimidad. Como ha recordado la STS 19 de febrero de 2009 (RJ 2009, 1620), recurso 6/2008, se trata de un elemento esencial del contrato de trabajo, de naturaleza contractual, laboral y profesional, no siendo necesario recabar el consentimiento previo del trabajador individual para que los representantes sindicales puedan acceder, en su caso, a dicho dato.

En cuanto a los datos de afiliación sindical, el TS ha seguido la doctrina del TC. Así, ha declarado la vulneración del derecho a la protección de datos y a la libertad sindical en un supuesto en que la afiliación del trabajador recurrente a determinado Sindicato, se facilitó con la única y exclusiva finalidad lícita de que la Empresa descontara de la retribución la cuota sindical y la transfiriera al Sindicato, de acuerdo con lo establecido en el art. 11.2 LOLS (RCL 1985, 1980). Sin embargo, el dato fue objeto de tratamiento automatizado y se hizo uso de la correspondiente clave informática para un propósito radicalmente distinto: retener la parte proporcional del salario relativa al período de huelga (STS 8 abril 2014 RJ 201414346).

En cuanto a la difusión de los datos de trabajadores en los censos electorales en las elecciones sindicales, más allá de su mera exposición -legalmente exigida - en el tablón de anuncios, el TS, en su STS 27 septiembre 2007, RJ 2007\7095, ha entendido que:

«si la totalidad de los datos profesionales y personales que contienen los censos laboral y electoral de la empresa demandada, recogidos en el núm. 2 de su hecho probado sexto, son objeto de la publicidad prevista y ordenada legalmente en el artículo 74.3 del Estatuto - lo que, sin perjuicio de la persecución de aquellas conductas concretas que pudieran sobrepasar los límites de las referidas leyes orgánicas, elimina la necesidad de solicitar y obtener un consentimiento personal específico como medio alternativo al contemplado en dichas normas-, es claro que no se produce la conculcación del artículo 18.1 CE y de la citada legalidad orgánica por el simple hecho de que a tal publicidad se le pueda ańadir otra complementaria, dirigida a determinadas entidades o agrupaciones, y con la exclusiva finalidad de facilitar su natural actividad sindical dentro de un muy concreto proceso electoral a representantes unitarios de los trabajadores, sobre todo cuando, como antes se dijo, la mejora que constituye esa extensión de la publicidad es el producto de un pacto colectivo del que sin duda se beneficia también el sindicato demandante y que no consta impugnado en forma alguna» ${ }^{42}$.

${ }^{42}$ En el mismo sentido, SAN núm. 38/2006, de 28 abril (AS 2006/2081). 


\subsubsection{Doctrina $A N$}

Sobre la ampliación por vía de Convenio Colectivo de los derechos de información, en concreto, al derecho del Comité intercentros a recibir anualmente una relación de todos los empleados de la empresa, con expresión de los conceptos económicos desglosados e individualizados, la SAN núm. 55/2006 de 7 junio (AS 200612223) se pronunció favorablemente, la ampliación de sus derechos de información aparece como medida apta para garantizar el respeto de las normas laborables. El reforzamiento de las facultades de información de los representantes legales, llamados a colaborar con las autoridades competentes en esta materia, ha de redundar necesariamente en una mayor efectividad de la actuación de estas últimas, y también de la Inspección de Trabajo, y consiguientemente, en un más exacto cumplimiento de las normas laborales, lo que corresponde a un interés público relevante, de suficiente entidad como para autorizar intromisiones en esferas personales que en principio pudieran considerarse reservadas en aplicación del art. 18.1 CE.

Se adicionan a las precedentes consideraciones las relativas a la protección última de los derechos de los trabajadores encomendada a quienes se articulan como receptores del los datos objeto de información y al deber de sigilo, configurado legalmente, finalidad aquélla justificadora de la dación a cargo del empresario de la información demandada. Cabría, por último, sumar igualmente, que desde la perspectiva de la autodeterminación informativa que más arriba se despejaba, no nos encontraríamos ante datos sensibles ni especialmente protegidos, regiría la regla prevista en el art. 6.2 de la LOPD relativa a la excepción de la regla del consentimiento cuando los datos de carácter personal use refieran a las partes de un contrato o precontrato de una relación negocial, laboral o administrativa y sean necesarios para su mantenimiento o cumplimiento", y en el régimen de comunicación a terceros (además de no incardinarse por la doctrina en el concepto de terceros a los citados representantes) quedaría exceptuado cuando la comunicación se fundamente en obligaciones legales, tal y como sucede en el caso de autos.

En el mismo sentido, se ha declarado el derecho del Comité de Empresa a recibir la copia del informe mensual que por cada trabajador la empresa debe realizar y entregar a cada empleado afectado donde conste día a día su jornada diaria con indicación de las horas trabajadas, a efectos del computo de los horas extraordinarias (y ello con independencia de que en el computo total de jornada estas horas puedan considerarse ordinarias o extraordinarias) (SAN núm. 14/2003 de 13 febrero, AS 2008\460).

El conflicto entre libertad sindical y protección de datos se evidencia en la SAN, (Sala Contenciosa) de 13 de junio 2007 (Rec. 367/2005), JUR 2007\199128, en que se confirma la sanción por la difusión de datos personales contenidos en una sentencia. La AN razona: no puede desconocerse que las sec- 
ciones sindicales y los órganos de representación de los trabajadores tienen reconocidas una serie de competencias para el ejercicio de sus funciones sindicales de representación y que están amparadas por el derecho a la libertad sindical reconocido en el artículo 28.1 de la Constitución, desarrollado a través de la Ley Orgánica 11/1985, de 2 de agosto de Libertad Sindical. Entre dichas funciones figura la del deber de mantener informados a sus representados «en todos los temas y cuestiones señalados... en cuanto directa o indirectamente tengan o puedan tener repercusión en las relaciones laborales» (art. 64.1.12 LET).

Ahora bien en la medida en que la información que se utilice al amparo de ese derecho de información sindical se refiera a datos de carácter personal de otros trabajadores, dicho tratamiento hay que enmarcarlo en el ámbito del derecho fundamental a la protección de datos, máxime cuando el trabajador en cuestión ha dejado ya de pertenecer a la empresa, como sucede en el caso de autos a tenor del contenido de la propia sentencia.

Nos encontramos por ello ante dos derechos fundamentales, el derecho a la libertad sindical y el derecho a la protección de datos. Ahora bien, como ha señalado el TC, véase STC 70/2003, de 12 de marzo «ningún derecho, ni siquiera los derechos fundamentales, es absoluto o ilimitado. Unas veces el propio precepto constitucional que lo consagra ya establece explícitamente los límites; en otras ocasiones, éstos derivan de la necesidad de preservar otros derechos o bienes constitucionalmente dignos de tutela (TC SS 11/1981, de 8 de abril, 2/1982, de 29 de enero, 91/1993, de 15 de marzo, 110/1994, de 11 de abril, 52/1995, de 23 de febrero, 37/1998, de 17 de febrero».

La libertad sindical no constituye, evidentemente, una excepción a esta regla (SSTC 81/1983, de 10 de octubre, 94/1995, de 19 de junio, 127/1995, de 25 de julio).

Se trata, por ello, de lograr un equilibrio entre ambos derechos, el derecho de información sindical y el derecho de protección de datos. En el caso de autos, el citado derecho de información sindical se satisface plenamente sin necesidad de identificar al trabajador en concreto al que se refiere la sentencia difundida, identificación que no es necesaria ni nada aporta a la tutela del citado derecho de libertad sindical por lo que no puede ampararse bajo el ropaje del citado derecho de libertad sindical.

En la misma línea, la SAN Sala de lo Contencioso-Administrativo 8 de julio de 2009 (JUR 20091351791), sanciona la difusión por internet de datos de trabajadores por parte de sindicatos, considerando proporcionada su difusión en la intranet. En este sentido, es fundamental que los tablones sindicales online se sitúen en las intranet de la empresa, nunca en Internet.

Si la información en cuestión se hubiera publicado en la intranet corporativa, a la vista de las circunstancias concurrentes, no se habría apreciado vulneración del de- 
recho a la protección de datos y seguramente el denunciante no hubiera puesto los hechos en conocimiento de la AEPD.

Lo que singulariza este caso respecto el contemplado en aquella sentencia, es que los datos de carácter personal: nombre, apellidos, categoría profesional (agente de movilidad) y número de carnet profesional, se publican en una página web en Internet y la publicación en dicha red no es idónea, necesaria ni proporcionada para mantener informados a los trabajadores en aquellas cuestiones que directa o indirectamente puedan repercutir en las relaciones laborales.

Este acceso a los datos personales del denunciante (...) a cualquier usuario de Internet es lo que singulariza este caso respecto del contemplado en la citada sentencia de 19 de diciembre de 2007 Por ello, a la vista de las circunstancias concretas concurrentes, considera la Sala que el derecho a la libertad sindical se puede satisfacer plenamente sin necesidad de publicar en Internet los datos personales del denunciante, por lo que la citada publicación no puede ampararse bajo el ropaje del citado derecho de libertad sindical.

En la línea expuesta, señalar que tampoco puede prevalecer el derecho de información veraz y los de libertad de expresión sobre el de protección de datos, pues pudo informarse sin aportar datos personales del denunciante en Internet, siendo este el criterio seguido en la sentencia de esta Sección de 16 de febrero de 2007 citada por la resolución impugnada, que contrariamente a lo alegado en la demanda, si presenta similitud con el presente. Además, la información publicada carece de relevancia pública e interés general, que son los factores predominantes que toma en consideración el Tribunal Constitucional para otorgar preferencia al derecho a la libertad de expresión.

En la misma línea, la SAN (Sala de lo Contencioso-Administrativo, Sección 1.a), de 8 febrero 2013. RJCA 2013\407, sanciona la publicación en la página web del sindicato de determinadas actas de inspección donde constaban los nombres de los trabajadores contratados en lugar de los huelguistas, publicación a la que se acompañaban calificativos como «esquiroles».

\subsubsection{Dotrina TSJ}

En STSJ Catalunya núm. 4350/2009 de 27 mayo. JUR 2009\409173, el TSJ considera que no vulnera el DPDP el deber de transmitir copias de los contratos que la ley impone al empleador en favor de los delegados sindicales (art. 10.1.3 LOLS):

Por otra parte aunque el artículo 11.1 de la Ley Orgánica de Protección de Datos prevé que: «los datos de carácter personal objeto del tratamiento sólo podrán ser comunicados a un tercero para el cumplimiento de fines directamente relacionados con las funciones legítimas del cedente y del cesionario con el previo consentimiento del interesado", en el apartado 2 exceptúa el consentimiento «a) Cuando la cesión está autorizada en una ley», lo que ocurre en el presente caso, pues el artículo 64 del Estatuto de los Trabajadores establece que «4... Asimismo, el comité de empresa tendrá derecho a recibir la copia básica de los contratos y la notificación de las prórrogas y de las denuncias correspondientes a los mismos en el plazo de diez días siguientes a que tuvieran lugar. 


\subsubsection{Criterios de la AEPD}

La AEPD ha tenido ocasión de pronunciarse en multitud de ocasiones sobre el conflicto existente entre los derechos de información y consulta de los representantes unitarios o sindicales y los derechos a la libertad sindical o a la información. En las próximas líneas trataremos de agrupar tales criterios en torno a las cuestiones más debatidas: la los datos profesionales y la cesión de datos a Comités de empresa o Secciones sindicales.

\section{A) Datos Profesionales: Retribuciones, RelaCiones de PUESTOS DE TRABAJO, NÓMINAS, ETC.}

En este punto cabe destacar el Informe $2016-0013^{43}$ en que se plantea si la solicitud del listado con nombres y apellidos del personal perteneciente al Consejo de Administración del Patrimonio Nacional, con el fin de conocer qué personas ocupan cada plaza de la Relación de Puestos de Trabajroes conforme a la LOPD. La AEPD concluye que si bien no es posible una comunicación masiva a los órganos de representación de los empleados públicos, sean estos funcionarios o laborales, sino que únicamente será posible, en caso de que resultara necesario para el ejercicio de su función de control, el acceso a los datos referidos a un empleado concreto que hubiera planteado una queja ante la misma. Ahora bien, la Ley 19/2013, de 9 de diciembre, de Transparencia, Acceso a la Información Pública y Buen Gobierno ha regulado el supuesto de hecho que nos ocupa. Su Capítulo III se refiere al derecho de acceso a la información pública; y en particular el artículo 15 regula la relación de tal derecho con la protección de datos de carácter personal.

El artículo 15.2 señala que "Con carácter general, y salvo que en el caso concreto prevalezca la protección de datos personales u otros derechos constitucionalmente protegidos sobre el interés público en la divulgación que lo impida, se concederá el acceso a información que contenga datos meramente identificativos relacionados con la organización, funcionamiento o actividad pública del órgano".

La AEPD considera que los datos de la relación o catálogo de puestos de trabajo, que consistan únicamente en los datos que deban figurar en dicha relación o catálogo junto con el nombre y apellidos de la persona que ocupa dicho puesto no son más que datos meramente identificativos relacionados con la organización, funcionamiento o actividad pública del órgano. Por tanto, son subsumibles el art. 15.2 transcrito y la regla general es favorable a la publicidad, a no ser que en el caso concreto deba prevalecer la protección de datos personales $\mathrm{u}$ otros derechos constitucionales.

43 http://www.agpd.es/portalwebAGPD/canaldocumentacion/informes_juridicos/cesion_datos/ common/pdfs/2016-0013_Comunicaci-oo-n-al-Comit-ee--Intercentros-del-nombre-y-apellidos-delos-ocupantes-de-RPT.pdf 
En el Informe 2014-0073 sobre la comunicación del salario del gerente a los socios ${ }^{44}$, la AEPD considera que el salario es un dato personal, pero que La Ley Orgánic 1/02 reguladora del derecho de asociación en su art. 21 contempla el derecho del socio a ser informado del estado de cuentas, cuentas en las que se incluirán los salarios de los trabajadores, y entre otros el salario del gerente, por lo que existe habilitación legal suficiente para la cesión pretendida.

En el Informe jurídico 2008-0491 la AEPD resuelve una consulta sobre cesión de datos de las nóminas de los trabajadores al Comité de Empresa ${ }^{45}$, y parte de que cualquier cesión de datos de los trabajadores al Comité de Empresa o Delegados de Personal que exceda de las legalmente previstas en el art. 64.1 y 9 ET deberá contar con el consentimiento del interesado, en este caso de los trabajadores afectados. Sin embargo, si existe un Convenio Colectivo que autoriza dicha cesión, la comunicación de datos planteada encontraría cabida en el apartado c) del artículo 11.2 de la LOPD, posibilitando que los datos se comuniquen al Comité de Empresa.

Por otro lado, el Comité de Empresa una vez recibidos los datos, hay que tener en cuenta que la comunicación a los órganos de representación de los trabajadores únicamente puede considerarse adecuada, conforme al art. 64.1 ET, dentro de las funciones de control que al mismo atribuye el ET. Por ello, cualquier utilización de los datos para una finalidad distinta de la citada o su posterior divulgación podría resultar contraria a lo dispuesto en la LOPD, por vulneración de lo dispuesto en el art. 4.2. Además, la divulgación podría incluso implicar una cesión de datos que debería encontrarse amparada por lo dispuesto en el artículo 11 LOPD. Asimismo en caso de que el Comité conserve los datos comunicados, incorporándolos a un fichero deberá dar cumplimiento a la obligación de seguridad impuesta por el art. 9 LOPD.

Para terminar con las cuestiones relativas a los datos profesionales, en el Informe jurídico 2009-0074, se planteó si era correcta la publicación en la web de un sindicato de datos de un concurso de traslado en Correos ${ }^{46}$, la AEPD consideró que sí era correcta, porque la facultad de informar a los trabajadores sobre cuestiones referidas a la movilidad y adjudicación de destinos, que otorga el artículo 8 LOLS, al sindicato consultante, podrá realizarse a través de la publicación de los resultados del concurso en el tablón de anuncios de los diferentes

\footnotetext{
${ }^{44}$ http://www.agpd.es/portalwebAGPD/canaldocumentacion/informes_juridicos/cesion_datos/ common/pdfs/2014-0073_Comunicaci-oo-n-de-salario-de-gerente-a-los-socios.pdf

$45 \mathrm{http} / /$ www.agpd.es/portalwebAGPD/canaldocumentacion/informes_juridicos/cesion_datos/ common/pdfs/2008-0491_Cesi-oo-n-de-datos-econ-oo-micos-de-las-n-oo-minas-de-los-trabajadores-al-Comit-ee--de-Empresa-por-Convenio.pdf

$46 \mathrm{http}: / /$ www.agpd.es/portalwebAGPD/canaldocumentacion/informes_juridicos/cesion_datos/ common/pdfs/2009-0074_Publicacioo-n-en-la-web-de-un-sindicato-de-datos-de-concurso-trasladoen-Correos-y-Tel-ee-grafos.-Consentimiento.pdf
} 
centros de trabajo, sin que la comunicación de los datos de los afectados pueda hacerse en un ámbito distinto al de la Sociedad Estatal, como sería su publicación a través de Internet.

\section{B) Cesión de datos a Comité de Empresa}

La AEPD se ha pronunciado en diversas ocasiones sobre la posibilidad de cesión de datos personales al Comité de empresa prevista en Convenio Colectivo. Así, sobre las diferentes "planillas o turnos de trabajo" que en el Convenio se prevé se comuniquen al Comité a efectos de conciliación de vida personal, familiar y laboral, la AEPD ha manifestado en su Informe 2006-0252 $2^{47}$ que dado que el trabajador se encuentra sometido a una relación laboral una de cuyas fuentes es el Convenio colectivo que prevé la cesión de los datos, cabría considerar que la comunicación de los datos resulta necesaria para el mantenimiento de la relación contractual, no cabiendo, en principio, que el afectado pueda oponerse a la misma. Igualmente, y en el mismo sentido, se pronuncia en el Informe 2010-0384 ${ }^{48}$.

En cuanto a la cesión de datos a Juntas de personal funcionario, en el Informe jurídico 2008-012049, la AEPD considera que «la función de vigilancia y protección de las condiciones de trabajo, atribuida a las Juntas de Personal por la Ley 9/1987 puede llevarse a adecuado desarrollo sin necesidad de proceder a una cesión masiva de los datos referentes al personal que presta sus servicios en el Órgano o Dependencia correspondiente. Sólo en el supuesto en que la vigilancia o control se refieran a un sujeto concreto, que haya planteado la correspondiente queja ante la Junta de Personal, será posible la cesión del dato especifico de dicha persona. En los demás supuestos, la función de control quedará plenamente satisfecha, a nuestro juicio, mediante la cesión a la Junta de Personal de información debidamente disociada, según el procedimiento definido en el artículo 3 f) de la Ley Orgánica 15/1999, que permita a aquélla conocer las circunstancias cuya vigilancia le ha sido encomendada sin referenciar la información en un sujeto concreto.

En consecuencia, procederá, en caso de haber sido formalmente solicitada, la cesión de los datos solicitados, siempre que los mismos sean cedidos de forma disociada, sin poder referenciar los datos a personas identificadas o identificables. En caso con-

47 http://www.agpd.es/portalwebAGPD/canaldocumentacion/informes_juridicos/cesion_datos/ common/pdfs/2006-0252_Cesi-oo-n-de-datos-al-Comit-ee--de-Empresa-prevista-en-Convenio-Colectivo.pdf

$48 \mathrm{http} / /$ www.agpd.es/portalwebAGPD/canaldocumentacion/informes_juridicos/cesion_datos/ common/pdfs/2010-0384_Cesi-oo-na-comit-ee--de-empresa-de-datos-de-trabajadores-prevista-enconvenio.-Oposici-oo-n-por-alg-uu-n-trabajador.pdf

$49 \mathrm{http}: / /$ www.agpd.es/portalwebAGPD/canaldocumentacion/informes_juridicos/cesion_datos/ common/pdfs/2008-0120_Comunicaci-oo-n-de-contratos-del-personal-laboral-de-un-ayuntamiento-a-un-delegado-sindical.pdf 
trario, deberá recabarse el consentimiento de los interesados, conforme exigen los artículos 11 y 21 de la LOPD».

\section{C) Cesión de datos a Secciones Sindicales}

También se ha planteado, en parecido sentido a los supuestos ya analizados de cesión e datos a los comités de Empresa, la problemática de la cesión de datos a los Delegados sindicales, en tanto que gozan de los mismos derechos de información cuando no forman parte del Cojité de Empresa (art. 10.3.1 LOLS). Así, por ejemplo:

— Informe jurídico 2008-085 Acceso a listados de personal de la policía municipal por sección sindical ${ }^{50}$.

— Informe jurídico 2008-0438 Cesión de datos de trabajadores a representantes sindicales ${ }^{51}$.

\subsection{Límites estatutarios}

Dentro de los límites que hallamos en el propio ET a los derechos de información, audiencia y consulta de los representantes de los trabajadores, hemos de destacar la finalidad de la información, el sigilo profesional y los secretos industriales, financieros o comerciales, ordenados de menos a más según el alcance de la restricción de los derechos de información de los representantes de los trabajadores.

\subsubsection{Finalidad de la información y ámbito de la empresa}

El art. 65.3 ET dispone que en todo caso, ningún tipo de documento entregado por la empresa al comité podrá ser utilizado fuera del estricto ámbito de aquélla ni para fines distintos de los que motivaron su entrega.

Este es un límite que juega respecto de todas las informaciones, pero en especial respecto de las no reservadas y sujetas al deber de sigilo, y que impone a los destinatarios de la información el uso razonable de la misma dentro de sus ámbito con respeto a los fines para los que le fue entregada (STS 13 diciembre 1989 (RJ 1989 \9200). Por supuesto, este límite se ve reforzado cuando existe un deber de sigilo de contenido más exigente que el mero uso razonable y en el caso de datos secretos no tiene sentido hablar de límite al derecho de información, pues este se ve anulado por el secreto.

50 http://www.agpd.es/portalwebAGPD/canaldocumentacion/informes_juridicos/cesion_datos/ common/pdfs/2008-0085_Acceso-a-listados-de-personal-de-la-polic-ii-a-municipal-por-secci-oo-nsindical.pdf

51 http://www.agpd.es/portalwebAGPD/canaldocumentacion/informes_juridicos/cesion_datos/ common/pdfs/2008-0437_Cesi-oo-nde-datos-de-trabajadores-a-representantes-sindicales.pdf 
Como hemos dicho ya, el derecho a la información tiene un carácter esencialmente instrumental: para el control, para la consulta y para la negociación; y es en marco de estos fines donde dicha información cobra sentido, por lo que su uso para fines particulares o distintos de los legalmente asignados sería un abuso de confianza o transgresión de la buena fe contractual que, en función de su gravedad, podría sancionarse incluso con el despido (art. 54.2 d y 58 ET).

Sin embargo, dicha conclusión ha de matizarse en el sentido de que el quebrantamiento del deber de sigilo profesional no puede ser merecedor del despido cuando se deba a una decisión colegiada y no individual, adoptada en el ejercicio de las funciones representativas (STSJ Madrid 6 febrero 2001, Recurso n. ${ }^{\circ}$ 5301/2000); por lo que en estos casos hay que entender de plena aplicación la teoría gradualista y habrá que estar al supuesto concreto, sin que puedan aventurarse reglas generales.

\subsubsection{Sigilo profesional}

El art. 68.2 y3 ET dispone que los miembros del comité de empresa y éste en su conjunto, así como, en su caso, los expertos que les asistan, deberán observar el deber de sigilo con respecto a aquella información que, en legítimo y objetivo interés de la empresa o del centro de trabajo, les haya sido expresamente comunicada con carácter reservado.

El deber de sigilo subsistirá incluso tras la expiración de su mandato e independientemente del lugar en que se encuentren.

Este deber de sigilo se extiende a los Delegados de Prevención por los arts. 30.4 y 37.3 LPRL. En cuanto a su alcance, el deber de siglo no es exigible en cualquier caso y respecto de cualquier tema sino sólo respecto de las materias que el legislador considere acreedoras de dicha confidencialidad ${ }^{52}$. Para que surja el deber se exige:

1) que la materia haya sido expresamente comunicada con carácter reservado

2) que exista un legítimo y objetivo interés de la empresa o centro.

En este sentido, no es suficiente que el empresario califique unilateralmente una determinada información como reservada, sino que es preciso que desde una óptica objetiva lo sea. Sobre tal necesidad objetiva de reserva se ha pronunciado el TC en su STC 213/02 de 11 de noviembre en que perfila el deber de sigilo y las facultades empresariales al respecto, al afirmar que la facultad empresarial de sujetar determinadas informaciones a la observancia del sigilo profesional no se configura ilimitadamente, sino con carácter restringido en cuanto limita el

52 STSJ Castilla-La Mancha de 24 de noviembre 2005 (Recurso n. ${ }^{\circ}$ 1858/2003). 
ejercicio de la función propia de los delegados sindicales. Es precisa una adecuación entre el alcance de la obligación de sigilo y los legítimos intereses empresariales, de manera que no es suficiente con que el empresario califique unilateralmente como confidencial cierta información, sino que es necesario también que desde una plano objetivo efectivamente lo sea.

Como límite inferior al deber de sigilo, podemos decir que las materias no sujetas al mismo lo están al respeto de los fines y ámbito del derecho de información, como ya hemos examinado con anterioridad.

Como límite superior del deber de sigilo están los secretos industriales, financieros o comerciales.

Como procedimiento específico para los litigios relativos al cumplimiento por los representantes de los trabajadores y los expertos que les asistan de su obligación de sigilo, la nueva LRJS, en su art. 153.3 contempla, en relación con el art. 65.5 ET, el proceso de conflicto colectivo.

Para terminar diremos que el deber de sigilo se erige en límite no sólo de los derechos de información, sino también de la libertad de expresión de los representantes de los trabajadores, pes tal debe impone evitar filtraciones a terceros ajenos a la empresa.

\subsubsection{Secretos industriales, financieros o comerciales}

$\mathrm{El}$ art. 65.4 ET dispone que excepcionalmente, la empresa no estará obligada a comunicar aquellas informaciones específicas relacionadas con secretos industriales, financieros o comerciales cuya divulgación pudiera, según criterios objetivos, obstaculizar el funcionamiento de la empresa o del centro de trabajo u ocasionar graves perjuicios en su estabilidad económica. Esta excepción no abarca aquellos datos que tengan relación con el volumen de empleo en la empresa.

El secreto es una información que la empresa no está obligada a comunicar. Encontramos un referente normativo de los secretos industriales en el art. 13 de la Ley 13/91 de 10 de enero sobre Competencia desleal, que considera como desleal la divulgación o explotación, sin autorización de su titular, de secretos industriales o de cualquier otra especie de secretos empresariales a los que se haya tenido acceso legítimamente, pero con deber de reserva, o ilegítimamente...

\section{Bibliografía}

ÁLVAREZ DEL CUVILLO, ANTONIO (2012): «Información consulta y participación de los trabajadores en la empresa», en NOGUEIRA GUASTAVINO, MAGDALENA (2012): Lecciones de derecho social de la Unión Europea, Tirant Lo Blanch, Valencia. 
DÍAZ PICAZO, LUIS MARÍA (2005): Sistema de Derechos Fundamentales, 2a, Madrid, Thomson-Civitas.

GALIANA MORENO, JESÚS MARÍA (1993): «El lento camino de gestación de la política social comunitaria: desde el Tratado de Roma a la cumbre de Maastricht», Revista Española de Derecho del Trabajo, núm. 58.

MONEREO PEREZ, JOSÉ LUIS (1992): Los derechos de información de los representantes de los trabajadores, Universidad de Granada, Granada.

MONEREO PEREZ, JOSÉ LUIS (1993): «La Carta comunitaria de derechos sociales fundamentales de los Trabajadores», Revista Española de Derecho del Trabajo, núm. 56-57.

MONEREO PEREZ, JOSÉ LUIS y MONEREO ATIENZA, CRISTINA (2012): La Europa de los Derechos. Estudio sistemático de la carta de los derechos fundamentales de la Unión Europea. Granada, Comares.

NAVARRO NIETO, FEDERICO; RODRÍGUEZ-PIŃERO ROYO, MIGUEL C. y GÓMEZ MUNOOZ, JOSÉ MANUEL (dir.) (2010): Manual de derecho social de la Unión Europea, Madrid, Tecnos.

PRECIADO DOMENECH, CARLOS HUGO (2016): Negociación colectiva en la empresa. Respuesta judicial a los problemas prácticos, Valladolid, Lex Nova.

VILLAVERDE MENÉNDEZ, IGNACIO et altri (2004): Teoría general de los derechos fundamentales en la Constitución española de 1978, Madrid, Tecnos.

\section{Jurisprudencia}

STJCE 5 octubre 1994, Asunto RFA, C-280/93.

STJCE 7 de febrero de 1985, Asunto ADHBU, C-240/83.

STJCE 8 junio 1994, Comisión contra Reino Unido, C-383/92.

STJCE 29 marzo 2001, Asunto Bertrriebsrat del Bofrost, C-62/99.

STJCE 8 febrero 2001, Caso Wolfgang Lange, Asunto C-350/99.

STJCE 13 enero 2004, Caso Nagel, Asunto C-440/00.

STJCE 4 octubre 2004, Caso Pflugradt, Asunto C-409/02.

STJCE 14 julio 2004, Asunto Bertriebsrat der firma ads ANDER

GMBH, C-349/01.

STJCE 13 enero 2004, asunto Gesambetriebsrat der Kuhne \&Angel AG \&/

Co KG, C-440/00.

STJCE 18 enero 2007, TJCE 2007\14 Caso Confederation generale du travail (CGT) otros contra Ministere de l'Emploi, de la Cohesion sociale et du Logement.

STJCE 5 julio 2007, Caso Comisión contra Reino de España. 
STJCE 18 diciembre 2008, Caso Ruben Andersen, Asunto C-306/07.

STJCE 10 septiembre 2009, Asunto Akavan Eritysalojen Kesfuliitto, C-44/08.

STJUE 11 febrero 2010, Caso Holsts, Asunto C-405/08.

STJUE 15 enero 2014. TJCE 2014l6, Caso Association de mediation sociale.

STJUE 30 abril 2014. Caso USDAW, Asunto C-80/14.

STJUE 13 mayo 2015, Caso Rabal Canas, Asunto C-392/13.

STJUE 13 mayo 2015, Caso Lyttle, Asunto C-182/13.

\section{Doctrina TS}

STS 06 mayo 2016, núm. 387/2016, RJ 201612713.

STS 19 abril 2016, núm. 297/2016, RJ $2016 \backslash 1975$.

STS 16 marzo 2016, núm. 228/2016, RJ 201612673.

STS 9 octubre 2015, RJ 201515665.

STS 8 julio 2014, RJ $2014 \backslash 4521$.

STS 18 junio 2013, RJ 201315738.

STS 20 junio 2012, RJ $2012 \backslash 9966$.

STS 17 enero 2012, RJ 2012\4969.

STS 13 octubre 2011, RJ 201117718.

STS 3 mayo 2011, RJ $2011 \backslash 4503$.

STS 29 marzo 2011, RJ 2011\3687.

STS 8 julio 2010. RJ $2010 \backslash 6795$.

STS 1 junio 2010. RJ $2010 \backslash 5933$.

STS 30 noviembre 2009, RJ $2009 \backslash 8029$.

STS 19 febrero 2009, RJ 2009\1620.

STS 3 octubre 2006, RJ 200618018.

STS 25 abril 2006, RJ $2006 \backslash 2397$.

STS 29 marzo 2006, RJ 200613306.

STS 19 diciembre 2005, RJ $2006 \backslash 1427$. 
STS 11 diciembre 2003, RJ 2004\2577.

STS 2 noviembre 1999, RJ $1999 \backslash 9108$.

STS de 11 marzo 1999, RJ $1999 \backslash 2912$.

STS 20 abril 1998, RJ $1998 \backslash 3480$.

STS 24 marzo 1998, RJ 1998\3009.

STS 20 diciembre 1997, RJ 1997\9525. 